\author{
UNIVERSIDADE DE SÃO PAULO \\ FACULDADE DE EDUCAÇÃO \\ PROGRAMA DE PÓS-GRADUAÇÃO EM EDUCAÇÃO \\ EDUCAÇÃO, LINGUAGEM E PSICOLOGIA
}

\title{
INGLÊS COMO LÍNGUA FRANCA SOB UM OLHAR CRÍTICO E DECOLONIAL
}

Dissertação de mestrado

\author{
Versão corrigida \\ Gabriela da Costa Rosa \\ Orientação: Prof. ${ }^{a}$ Dra. Ana Paula Martinez Duboc
}

São Paulo 


\author{
UNIVERSIDADE DE SÃO PAULO \\ FACULDADE DE EDUCAÇÃO \\ PROGRAMA DE PÓS-GRADUAÇÃO EM EDUCAÇÃO \\ EDUCAÇÃO, LINGUAGEM E PSICOLOGIA
}

\title{
INGLÊS COMO LÍNGUA FRANCA SOB UM OLHAR CRÍTICO E DECOLONIAL
}

GABRIELA DA COSTA ROSA

\begin{abstract}
Dissertação apresentada ao Programa de PósGraduação em Linguagem e Educação da Faculdade de Educação da Universidade de São Paulo para obtenção do título de Mestre em Educação.
\end{abstract}

Orientadora: Prof. ${ }^{a}$ Dra. Ana Paula Martinez Duboc

São Paulo 
Autorizo a reprodução e divulgação total ou parcial deste trabalho, por qualquer meio convencional ou eletrônico, para fins de estudo e pesquisa, desde que citada a fonte. Bibliotecária da FE/USP: Nicolly Soares Leite - CRB-8/8204

Rosa, Gabriela da Costa
Ri Inglês como Língua Franca sob um olhar crítico e decolonial / Gabriela da Costa Rosa; orientadora Ana Paula Martinez Duboc. -- São Paulo, 2021. $125 \mathrm{p}$.

Dissertação (Mestrado - Programa de Pós-Graduação Educação, Linguagem e Psicologia) -- Faculdade de Educação, Universidade de São Paulo, 2021.

1. Inglês como Língua Franca. 2. interculturalidade. 3. currículo. 4. pensamento decolonial. 5. Linguística Aplicada Crítica. I. Duboc, Ana Paula Martinez, orient. II. Título. 
ROSA, Gabriela da Costa. Inglês como Língua Franca sob um olhar crítico e decolonial. 125f. Dissertação (Mestrado) - Faculdade de Educação. Universidade de São Paulo. São Paulo. 2021.

\section{Banca Examinadora}

Profa. Dra. Ana Paula Martinez Duboc

Instituição: Universidade de São Paulo

Assinatura:

Julgamento:

Prof. Dr. Domingos Sávio Pimentel Siqueira

Instituição: Universidade Federal da Bahia

Assinatura:

Julgamento:

Prof. Dr. Lynn Mario Menezes de Souza

Instituição: Universidade de São Paulo

Assinatura:

Julgamento: 


\section{AGRADECIMENTOS}

À Profa. Dra. Ana Paula Martinez Duboc, pelo entusiasmo que sempre demonstrou e que muito me inspirou durante a elaboração deste trabalho, e pelo cuidado, preocupação e sensibilidade que teve como orientadora.

Ao Prof. Dr. Lynn Mario Menezes de Souza, pelas ricas contribuições no Exame de Qualificação e pelas aulas que sempre me provocaram muitas reflexões.

Ao Prof. Dr. Domingos Sávio Pimentel Siqueira, pelas cuidadosas sugestões no Exame de Qualificação e pela acolhida nos encontros do Grupo de Pesquisa ILF BRASIL-UFBA, que proporcionaram contribuições valiosas para este trabalho.

Aos amigos que acompanharam meu ingresso e percurso no mestrado, especialmente Lucas, pela detalhada revisão e por todo o apoio; Hana, por se fazer perto, mesmo de longe; e Dayane, por ajudar a encurtar e tornar mais leves os últimos longos meses.

Aos meus pais Paula e Eduardo, meu irmão Ricardo e minha tia Eliana, pelo suporte e incentivo que sempre me deram, cada um à sua maneira, que permitiram que eu nunca parasse de aprender e por celebrarem comigo todas as conquistas. 


\section{RESUMO}

O conceito de Inglês como Língua Franca (ILF) vem ganhando destaque em pesquisas do campo da linguagem, tanto no cenário internacional, a partir dos primeiros estudos na área realizados na Europa, quanto nacional, sendo ressignificado por pesquisadores brasileiros. Além disso, ILF se apresenta como a perspectiva que embasa o componente curricular Língua Inglesa em três diferentes documentos que regulam a Educação Básica brasileira, a saber, no âmbito nacional, a Base Nacional Comum Curricular - Ensino Fundamental (2017), e, no âmbito local, os Direitos de aprendizagem dos ciclos interdisciplinar e autoral: Língua Inglesa (2016) e o Currículo da Cidade: Ensino Fundamental: Língua Inglesa (2017), ambos da Rede Municipal de Educação da cidade de São Paulo, o que torna relevante e necessária a produção de conhecimento sobre o termo. Partindo do lócus de enunciação do pensamento decolonial e da Linguística Aplicada Crítica, essa pesquisa tem como objetivo investigar as bases epistemológicas e ontológicas do conceito de ILF tanto na produção científica de pesquisadores internacionais e nacionais, quanto nos documentos curriculares mencionados anteriormente, de modo a compreender como as noções de língua/linguagem, cultura, sujeito, conhecimento e sociedade são concebidas. A análise de textos teóricos aponta para uma complexa teia de sentidos no entorno do conceito de ILF e para a perpetuação da colonialidade no interior desse campo de estudos. Em relação aos documentos curriculares, a pesquisa permitiu identificar apropriações discursivas conflitantes do conceito, as quais poderão servir ora para a manutenção de uma função estritamente instrumental e/ou mercadológica do inglês ora para a potencialidade do seu papel crítico e político no interior do currículo.

Palavras-chave: Inglês como Língua Franca; interculturalidade; currículo; pensamento decolonial; Linguística Aplicada Crítica. 


\begin{abstract}
The concept of English as a Lingua Franca (ELF) has received great prominence in language studies, both in international and national settings, since the first studies carried out in Europe until its reinterpretation by Brazilian scholars. In addition, the ELF perspective underlies the English language guidelines in three different curricular policies in Brazilian Basic Education, namely, in a global level, the National Common Core Curriculum - Elementary School (2017), and, in a local level, Learning rights, authorship and interdisciplinarity in dialogue: English language (2016) and The City Curriculum: Elementary School: English language (2017), both from the Municipal Secretariat of Education of the City of São Paulo. Knowledge production regarding this concept is thus relevant and essential. Departing from decolonial thinking and Critical Applied Linguistic, this research aims at investigating the epistemological and ontological basis underlying the concept of ELF in national and international scientific studies and in the curricular guidelines mentioned above, in order to understand how language, culture, subject, knowledge and society are conceived. The analysis of theoretical texts points to a complex web of meanings surrounding the concept of ELF and to the prevalence of coloniality in this field of study. Regarding the curricular guidelines, the research suggests conflicting discursive appropriation of ELF serving either an instrumental function and market interests of the language or its potential for a critical and political function in the curriculum.
\end{abstract}

Keywords: English as a Lingua Franca; interculturality; curriculum; decolonial thinking; Critical Applied Linguistics. 


\section{LISTA DE ABREVIATURAS}

ASL - Aquisição de Segunda Língua

BNCC - Base Nacional Comum Curricular

EFL - English as a Foreign Language

ELF - English as a Lingua Franca

ILA - Inglês como Língua Adicional

ILE - Inglês como Língua Estrangeira

ILF - Inglês como Língua Franca

ILG - Inglês como Língua Global

LAC - Linguística Aplicada Crítica

LFE - Lingua Franca English

SMESP - Secretaria Municipal de Educação de São Paulo

WE - World Englishes 


\section{LISTA DE FIGURAS}

Figura 1 - Macrovisão do movimento investigativo

Figura 2 - Países que sediaram o evento International Conference of English as a Lingua

Franca

Figura 3 - Local de trabalho dos convidados a keynote speakers e convidados para apresentação de colóquios e plenárias 76

Figura 4 - Teia de sentidos no entorno do conceito de ILF 80

Figura 5 - Eixos estruturantes do Currículo de Língua Inglesa 98

Figura 6 - Direitos de Aprendizagem de Língua Inglesa 99

Figura 7 - Tabelas do Componente Curricular Língua Inglesa na BNCC 103

Figura 8-Quadro de objetivos de aprendizagem e desenvolvimento 110 


\section{LISTA DE QUADROS}

Quadro 1 - Comparação entre os três documentos reguladores analisados 114 


\section{SUMÁRIO}

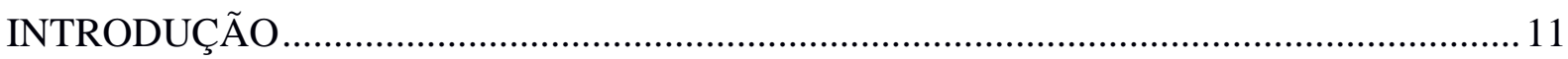

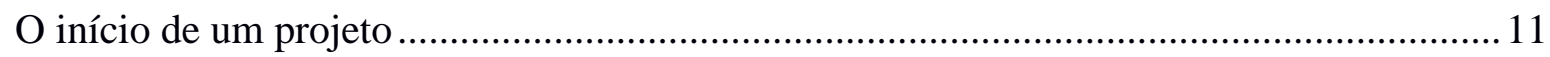

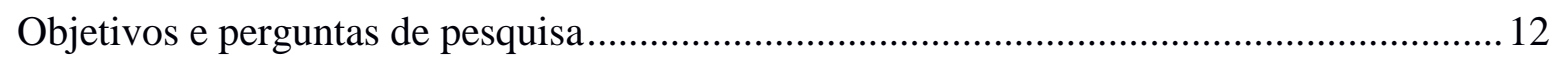

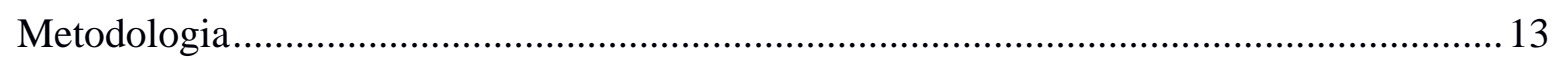

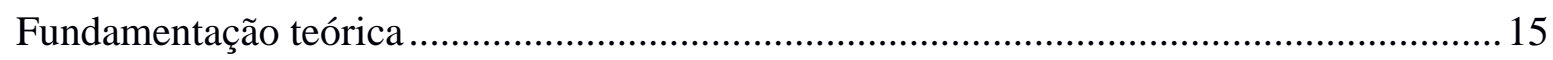

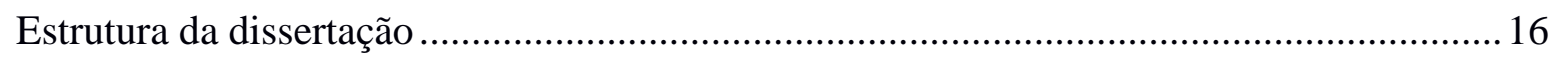

CAPÍTULO 1 - LINGUAGEM E (DE)COLONIALIDADE ............................................ 17

CAPÍTULO 2 - INGLÊS COMO LÍNGUA FRANCA: SENTIDOS EM DISPUTA .............31

2.1 Para além do ILF: as diferentes terminologias circulantes nos estudos da linguagem... 31

2.2 ILF no Norte Global: gênese e crítica ................................................................. 35

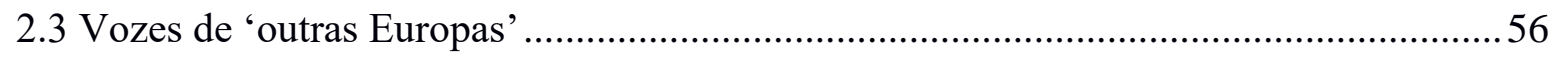

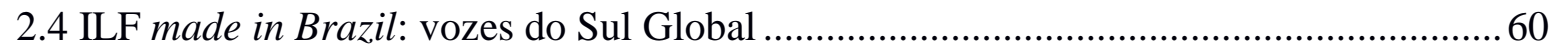

2.5 Questões ontológicas nos estudos de ILF: que vozes falam mais alto? ....................... 74

CAPÍTULO 3 - ILF EM CAMPO: UM OLHAR ÀS PROPOSTAS CURRICULARES........81

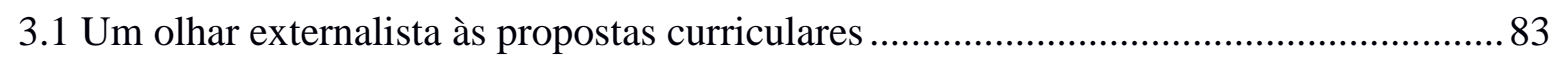

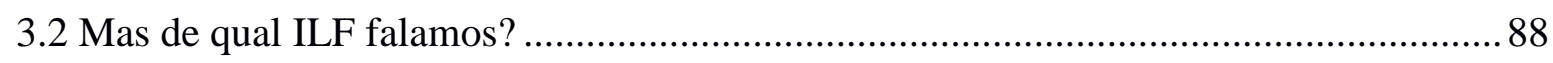

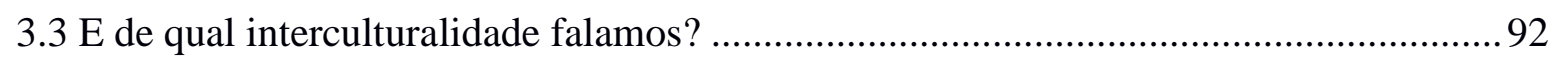

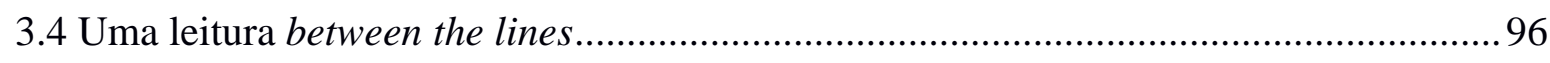

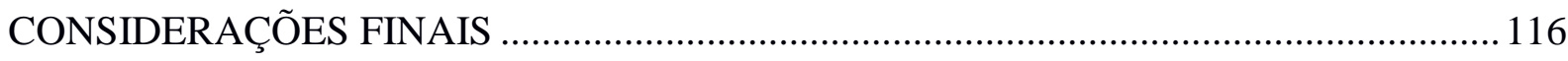

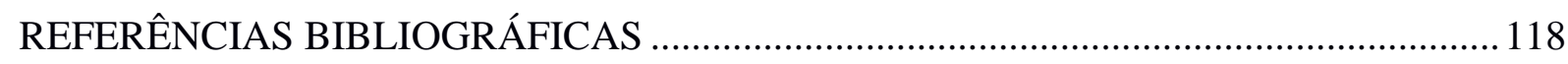




\section{INTRODUÇÃO}

\section{O início de um projeto}

Além de apresentar os objetivos desta pesquisa, as perguntas que a norteiam e as teorias nas quais ela se apoia, dedico-me inicialmente a uma breve contextualização de como o interesse pelo tema do Inglês como Língua Franca foi sendo construído e como o trabalho tomou a forma que hoje é aqui apresentada.

Enquanto aluna de graduação em Letras na Faculdade de Filosofia, Letras e Ciências Humanas da Universidade de São Paulo, tive a oportunidade de desconstruir e reconstruir muitos dos sentidos acerca do ensino de língua inglesa concebidos ao longo de minha experiência como aluna, tanto das redes pública e privada de ensino de São Paulo quanto do instituto de idioma no qual estudei inglês durante alguns anos. Nos meus anos finais do Ensino Fundamental, o desejo de um dia tornar-me professora de inglês já estava presente, mas aquilo que aprendi enquanto aluna na Educação Básica, em sua maior parte de escolas públicas, não me parecia suficiente para o meu objetivo, por isso me dediquei ao estudo da língua em instituto de idiomas. Ao mesmo tempo em que essa "ineficiência" no aprendizado da língua em escolas regulares me incomodava e me parecia algo possível de ser transformado, a oposição entre a escola pública como o lugar da falta e a escola de idiomas como o lugar ideal foi sendo construída por mim.

Como aprendiz da língua e com o objetivo de me tornar professora, o "domínio" do idioma também era algo que para mim se mostrava imprescindível, o que significava, dentre outras coisas, aproximar-me tanto quanto fosse possível dos usos comumente atribuídos a um falante nativo. Enquanto estudante de Letras, entretanto, tive contato com outras perspectivas que me fizeram questionar construções como o binarismo falante nativo e não-nativo, língua alvo, proficiência e domínio linguístico, imitação, deficiência, dentre outros construtos que tradicionalmente permearam, e ainda permeiam, o campo da Aquisição de Segunda Língua, mas que também passaram a ser questionados por estudiosos da linguagem diante da realidade multilíngue na qual vivemos (FIRTH; WAGNER, 1997; CANAGARAJAH; WURR, 2011; THE DOUGLAS FIR GROUP, 2016).

Diante dessas novas visões, o ensino de língua inglesa na escola tornou-se para mim, em vez de deficiente, um desafio pela sua complexidade no papel que deveria desempenhar na formação dos sujeitos. Do mesmo modo, a noção do falante nativo, da proficiência linguística 
e as suas implicações foram se tornando cada vez mais algo a ser problematizado do que um modelo a ser imitado e um objetivo a ser atingido.

Em algumas experiências de estágio que vivenciei nas salas de aula de inglês em escolas públicas, notei que os contextos observados em muito se pareciam com aqueles de minha época de estudante. A oralidade em língua inglesa praticamente não se fazia presente, nem na forma de imitação de um modelo nativo nem de sua problematização.

Foram essas percepções e inquietações que me levaram à elaboração de um projeto de mestrado que, em seu início, tinha como objetivo investigar o ensino de pronúncia da língua inglesa no contexto público de educação e propor que ele fosse desenvolvido com base no paradigma do Inglês como Língua Internacional (ILI), perspectiva que, naquele momento, me parecia a alternativa mais adequada e viável para as questões que eu observava e coerente com o modo que eu entendia a oralidade, o que viria a mudar ao longo da pós-graduação.

As leituras sobre as diversas terminologias circulantes nos estudos do inglês me levaram à compreensão das bases epistemológicas de cada uma delas e fizeram com que eu voltasse minha atenção para a noção do Inglês como Língua Franca (doravante ILF), perspectiva muito debatida, exaltada e também criticada atualmente entre os estudiosos da linguagem, tanto no âmbito nacional quanto internacional. Além de estar presente no debate teórico, o estudo do conceito se mostrou ainda mais relevante pela sua adoção em três propostas curriculares brasileiras nos últimos anos.

Mesmo que, no momento do meu ingresso no mestrado, minha intenção fosse abordar o ensino de inglês partindo de uma perspectiva crítica, problematizadora e pautada na diferença, minhas concepções acerca da língua e do conhecimento estavam ainda muito ligadas a pressupostos da modernidade que depois eu passei a questionar, ressignificando minhas próprias bases epistemológicas ao longo desse percurso.

\section{Objetivos e perguntas de pesquisa}

Esta pesquisa buscou compreender as diferentes bases epistemológicas e ontológicas nas quais o conceito de ILF se insere no que diz respeito à sua apropriação por recentes documentos reguladores da Educação Básica brasileira, bem como em relação ao próprio estudo do conceito no campo científico. A escolha pelo estudo do termo se dá pelo fato de que atualmente diversos currículos de Educação Básica são fundamentados pela perspectiva de ILF, havendo, então, a necessidade de desenvolvimento de pesquisas que possam contribuir para a produção de conhecimento a esse respeito. 
Para isso, apresentamos um estado-da-arte do termo desde sua gênese no norte global até as atuais reinterpretações do conceito por estudiosos do tema no cenário nacional e internacional. Em seguida, analisamos a presença do termo ILF em documentos curriculares da Educação Básica brasileira, a saber: os Direitos de aprendizagem dos ciclos interdisciplinar e autoral: Língua Inglesa, publicado em 2016, a Base Nacional Comum Curricular - Ensino Fundamental - Língua Inglesa e o Currículo da Cidade: Ensino Fundamental: Língua Inglesa, publicados em 2017. Para alcançar esses objetivos, a pesquisa se orientou através das seguintes perguntas:

1. Como ILF é definido na produção científica nacional e internacional? Que bases ontológicas e epistemológicas fundamentam os diferentes entendimentos do conceito circulantes no campo dos estudos da linguagem?

2. De que maneira o conceito de ILF é apropriado por cada um dos documentos reguladores? Em quais bases ontológicas e epistemológicas o conceito se insere?

\section{Metodologia}

A metodologia empregada para responder essas questões se baseou inicialmente nas definições de pesquisa bibliográfica e pesquisa documental. A primeira é entendida como uma "modalidade de estudo e análise de documentos de domínio científico, tais como livros, periódicos, enciclopédias, ensaios críticos, dicionários e artigos científicos" (OLIVEIRA, 2007, p. 69), que tem como objetivo coletar informações sobre o tema em estudo através do contato com fontes secundárias, que já são reconhecidas como pertencentes ao domínio científico (OLIVEIRA, 2007). A segunda é caracterizada pela "busca de informações em documentos que não receberam nenhum tratamento científico" (OLIVEIRA, 2007, p. 69, grifo da autora), o que a autora chama de fontes primárias, como é o caso dos documentos sob análise neste estudo. Entretanto, a adoção integral de tais metodologias não corresponderia exatamente ao que pretendíamos fazer, uma vez que tais tipologias de pesquisa implicam determinados pressupostos do fazer científico moderno que não dialogam com o lócus do qual partimos e com o modo como concebemos o conhecimento, uma vez que pressupõem a possibilidade de alcançar a totalidade, a objetividade e a neutralidade, através da necessidade de "constituir um corpus satisfatório, esgotar todas as pistas capazes de lhe fornecer informações interessantes" (CELLARD, 2008, p. 298 apud SÁ-SILVA; ALMEIDA; GUINDANI, 2009, p. 3) e de eliminar: 
comportamentos pesquisados, anulando a possibilidade de reação do sujeito à operação de medida (KELLY apud SÁ-SILVA; ALMEIDA; GUINDANI, 2009, p. $3)$.

Por isso, optamos pelo paradigma indiciário de Ginzburg (1989) como uma inspiração metodológica que nos parece mais coerente com os objetivos aqui propostos e com as teorias nas quais nos baseamos. Tal paradigma se mostra como uma alternativa metodológica para as ciências humanas por proporcionar o que o próprio autor chama de "rigor flexível" (GINZBURG, 1989, p. 179), sendo adotado e defendido em alguns trabalhos recentes da área de humanidades, dos estudos da linguagem e da educação, como nos trabalhos de Suassuna (2008), Sousa, Garcia e Faria (2014) e Dell'Olio (2018).

Para definir o paradigma indiciário, Ginzburg traça um paralelo entre os métodos utilizados por Morelli, Holmes e Freud, que se assemelham pela busca por indícios e traços, e pela atenção nos detalhes. Era o que fazia, por exemplo, o historiador Giovanni Morelli no final do século XIX, com o objetivo de distinguir entre as obras originais de grandes pintores e as cópias de tais produções. Para isso, Morelli argumentava que:

[...] é preciso não se basear, como normalmente se faz, em características mais vistosas, portanto mais facilmente imitáveis, dos quadros: os olhos erguidos para o céu dos personagens de Perugino, o sorriso dos de Leonardo, e assim por diante. Pelo contrário, é necessário examinar os pormenores mais negligenciáveis, e menos influenciados pelas características da escola a que o pintor pertencia: os lóbulos das orelhas, as unhas, as formas dos dedos das mãos e dos pés" (GINZBURG, 1989, p. 144).

São, portanto, os detalhes marginais que se mostram reveladores. Tal procedimento na análise de obras de arte é equiparado ainda ao trabalho detetivesco que Arthur Conan Doyle atribuiu a seu personagem Sherlock Holmes, ao afirmar que "o conhecedor de arte é comparável ao detetive que descobre o autor do crime (do quadro) baseado em indícios imperceptíveis para a maioria" (GINZBURG, 1989, p. 145). Além da comparação com o trabalho de um detetive, o método de Morelli foi também equiparado por Freud com o trabalho do psicanalista em seu ensaio "Os Moisés de Michelangelo":

Creio que o seu método está estreitamente aparentado à técnica da psicanálise médica. Este também tem por hábito penetrar em coisas concretas e ocultas através de elementos pouco notados ou desapercebidos, dos detritos ou 'refugos' da nossa observação (FREUD, 1914 apud GINZBURG, 1989, p. 147).

Ao nos inspirarmos no paradigma indiciário para o estudo do conceito de ILF, adotamos um método interpretativo voltado para os detalhes e pormenores, para os dados marginais, secundários, e para as informações descartadas ou usualmente ignoradas, em busca de pistas, indícios e rastros considerados reveladores. Conforme buscamos representar na Figura 1 a seguir, é essa atitude e esse olhar detetivesco que pretendemos imprimir neste trabalho, como 
se, ao aproximarmos uma lupa sobre a superfície do conceito de ILF, buscássemos enxergar as concepções mais profundas nas quais ele se embasa. Assim é que essa pesquisa partiu de diferentes materiais para a geração de dados, a saber: literatura acerca de ILF, programações do evento International Conference of English as a Lingua Franca, documentos curriculares brasileiros fundamentados pelo conceito de ILF e pareceres críticos referentes a esses documentos elaborados por agentes do campo acadêmico brasileiro.

\section{Figura 1 - Macrovisão do movimento investigativo}

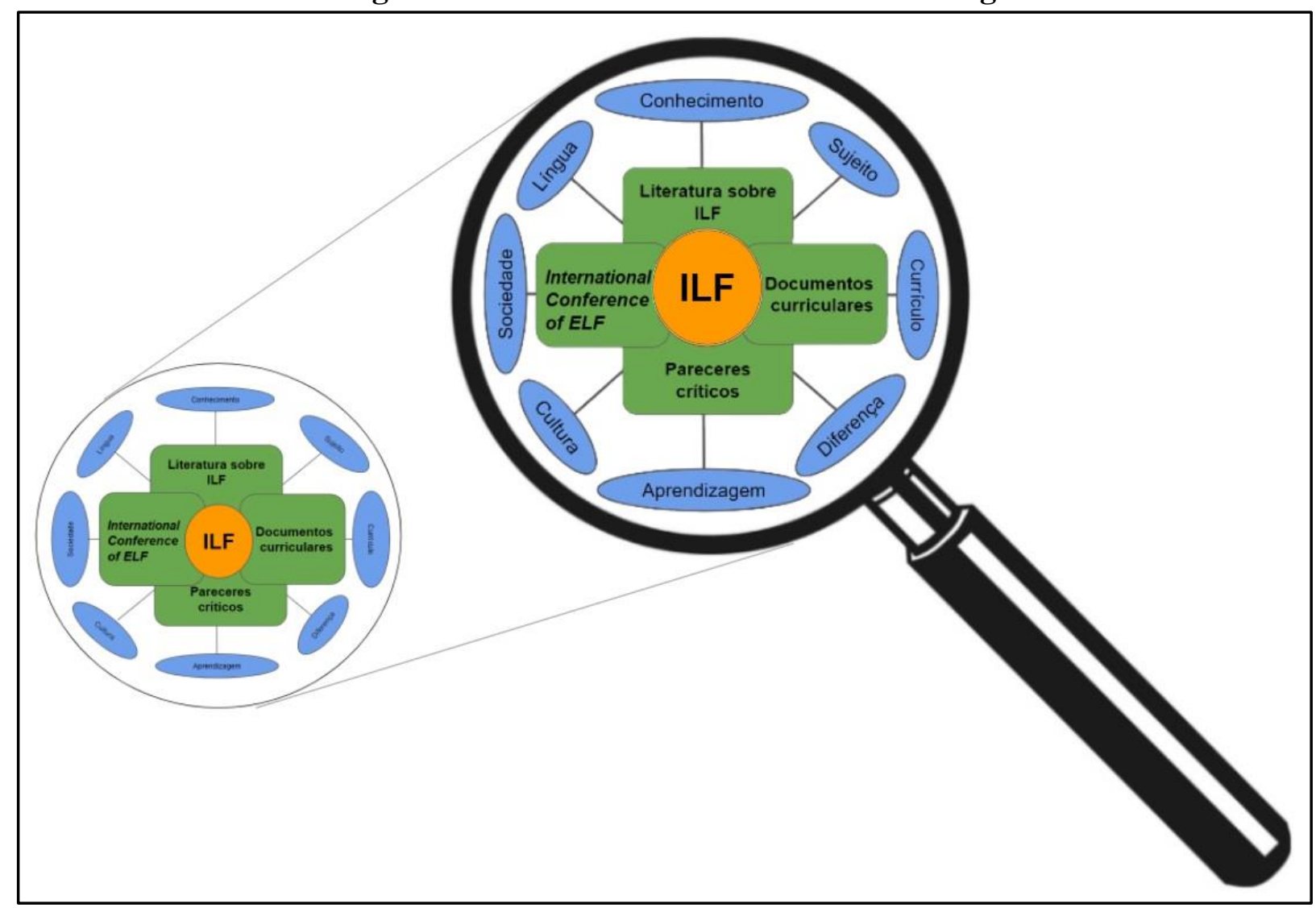

Fonte: elaboração própria

\section{Fundamentação teórica}

Esta pesquisa se baseia no referencial teórico oferecido pela Linguística Aplicada Crítica (LAC) e pelo pensamento decolonial. Ao relacionar o estudo de ILF a essas teorias, partimos de uma perspectiva crítica, reconhecendo as relações de colonialidade e poder que permeiam o uso e a aprendizagem do inglês enquanto língua global, além das próprias pesquisas sobre o conceito. Partimos das contribuições dos linguistas aplicados Canagarajah $(2013,2017)$ e Pennycook (2004, 2006) e dos pensadores decoloniais Mignolo (2007), Walsh (2007, 2012), Mignolo e Walsh (2018), Sousa Santos (2007), Grosfoguel (2007), Castro-Gómez (2007), Quijano (2007), Maldonado Torres (2007) e Garcés (2007). Sobre o campo de ILF, buscamos 
trabalhos internacionais e nacionais sobre o tema em Jenkins (2000, 2005, 2006a, 2006b, 2009, 2011, 2015, 2017), Seidlhofer (1999, 2001, 2005, 2009, 2017), Siqueira (2011, 2012, 2015, 2018), Duboc (2018, 2019), Jordão (2014, 2018), Gimenez; Calvo e El Kadri (2015) e Gimenez; El Kadri e Calvo (2018). Para a análise dos documentos, utilizamos teóricos sobre currículo como Silva (2019), Libâneo (2016) e o conceito de campo de Bourdieu (2004).

\section{Estrutura da dissertação}

O texto aqui apresentado estrutura-se da seguinte forma: O Capítulo 1 apresenta os principais conceitos e teorias que embasam a pesquisa e a análise aqui propostas. O Capítulo 2 é dedicado à discussão das diferentes terminologias circulantes nos estudos sobre a língua inglesa, para então nos voltarmos sobre os sentidos construídos em torno do acrônimo ILF, desde os trabalhos precursores do campo desenvolvidos na Europa até as mais recentes teorizações, inclusive por pesquisadores brasileiros do tema. O Capítulo 3 analisa a presença do conceito ILF em diferentes políticas da Educação Básica brasileira, buscando compreender de que forma essa perspectiva é apropriada por cada documento. 


\section{CAPÍTULO 1 - LINGUAGEM E (DE)COLONIALIDADE}

Os ninguéns: os filhos de ninguém, os donos de nada. Os ninguéns: os nenhuns, correndo soltos, morrendo a vida, fodidos e mal pagos:

Que não são embora sejam.

Que não falam idiomas, falam dialetos. Que não praticam religiões, praticam superstições.

Que não fazem arte, fazem artesanato. Que não são seres humanos, são recursos humanos. Que não têm cultura, têm folclore.

Que não têm cara, têm braços.

Que não têm nome, têm número.

Que não aparecem na história universal, aparecem nas páginas policiais da imprensa local. Os ninguéns, que custam menos do que a bala que os mata.

Eduardo Galeano

O estudo toma como lócus de enunciação o debate da pós-modernidade, com ênfase para a intersecção entre o pensamento decolonial e a Linguística Aplicada Crítica (LAC). Partir desse lócus acarreta uma compreensão de língua, cultura, sujeito e conhecimento que problematiza a visão homogênea e universalizante característica da Modernidade. Por isso, dedicamo-nos neste primeiro capítulo à apresentação das concepções nas quais este trabalho se apoia e o referencial teórico que as embasam.

Partimos de uma visão que reconhece a heterogeneidade constitutiva da língua e da cultura, de uma perspectiva que entende o sujeito como capaz de performar identidades múltiplas e o conhecimento como localizado e construído socialmente. Apresentaremos agora diferentes visões sobre essas concepções através de teóricos da pós-modernidade, da LAC e do pensamento decolonial, a fim de marcar nosso lócus de forma mais aprofundada.

De acordo com Hall (1997), uma das formas de entender a linguagem é através da visão mimética ou reflexiva, correspondente à visão aristotélica, segundo a qual a língua funciona apenas como imitação de uma realidade pronta e acabada, cujo objetivo é refletir os significados fixos nela existentes. A segunda abordagem mencionada pelo autor é a intencional, predominante na Modernidade, na qual a língua funciona como meio de transmitir os 
pensamentos do indivíduo, ou seja, como instrumento de comunicação de sentidos também fixos e produzidos apenas pelo falante. Menezes de Souza (2010, p. 291) acrescenta que essa visão de língua buscava a padronização e a homogeneização e foi idealizada por Locke no projeto de Modernidade com o objetivo de garantir:

[...] o pensamento claro, direto, puro e reflexivo; ou seja, uma língua desinteressada que permitisse o acesso à verdade das coisas, tais como são. Como tal, essa língua pura, pública e desinteressada, teria como resultado unificar e eliminar diferenças, propiciando as condições ideais para acessar e usar a verdade, uma vez que tal verdade era única, unitária e universal.

A Linguística tomou o monolinguismo como modelo teórico, partindo da ideia de uma comunidade linguisticamente homogênea, o que não passa de uma idealização. Canagarajah e Wurr (2011) afirmam que essa ideia abstrata de língua enquanto estrutura rígida e monolítica é falsa, e embora tenha sido uma simplificação necessária no estágio inicial de desenvolvimento da Linguística, pode agora ser substituída por modelos mais sofisticados. Os autores criticam o fato de esse modelo teórico ainda prevalecer no campo da Linguística, enfatizando os interesses e privilégios implicados:

[...] as premissas dos modelos dominantes não servem apenas à conveniência acadêmica. Estudiosos pós-coloniais e subalternos consideram o conhecimento como implicado (Pennycook, 2001; Makoni, 2002). Nesse sentido, os modelos dominantes da linguística confirmam a ideologia dos estados e identidades monolíngues detidas por comunidades privilegiadas no Ocidente. Haveria interesses declarados particulares em manter paradigmas monolíngues? (CANAGARAJAH; WURR, 2011, p. 9) $)^{12}$

Ainda a respeito do monolinguismo, alguns estudos desconstroem essa idealização, comentando sobre sociedades não-ocidentais nas quais o mesmo território abriga uma imensa variedade de línguas, que permeiam as interações do dia a dia, como em comunidades sul asiáticas (CANAGARAJAH; WURR, 2011) e em partes da África (THE DOUGLAS FIR GROUP, 2016). Mesmo nas sociedades ocidentais, o monolinguismo não passa de uma construção que daria unidade ao estado-nação. Como afirmam Canagarajah e Wurr (2011, p. 9):

Como afirma Dorian (2004), o monolinguismo é uma invenção recente mesmo no Ocidente: "O monolinguismo, agora considerado como a condição não marcada por membros do grupo linguístico dominante nos estado-nação modernos, era menos predominante antes que a ascensão do estado-nação deu a ele uma aprovação especial"

\footnotetext{
${ }^{1}$ Todas as citações originais ao longo do trabalho foram traduzidas pela autora.

2 [...] the assumptions of the dominant models do not serve only academic convenience. Postcolonial and subaltern scholars consider knowledge as interested (Pennycook, 2001; Makoni, 2002). In this sense, the dominant models of linguistics confirm the ideology of monolingual states and identities held by privileged communities in the West. Could there be vested interests in holding on to monolingual paradigms?
} 
(p. 438). As diversas línguas e os encontros multilíngues em comunidades Ocidentais foram ignorados na academia e, em alguns casos, socialmente suprimidos. ${ }^{3}$

Assim como uma visão de língua homogênea contribuiria para criar a ideia de uma nação unificada, a tentativa de unificar a cultura, apagando as diferenças, também serviria a esse propósito (MENEZES DE SOUZA, 2010). Ao tratar da construção da identidade nacional, Hall (2005) também se refere à tentativa de apagamento das diferenças. Para ele, as culturas nacionais devem ser pensadas como um "dispositivo discursivo que representa a diferença como unidade ou identidade" (HALL, 2005, p. 61). Apesar da heterogeneidade existente entre seus membros, a cultura nacional os unifica em torno de uma identidade cultural através do discurso, construindo sentidos que influenciam suas ações e organizam as concepções sobre si mesmos. Como uma característica da industrialização e um dispositivo da modernidade, a construção de uma cultura nacional "generalizou uma única língua vernacular como o meio dominante de comunicação em toda a nação, criou uma cultura homogênea e manteve instituições nacionais, como, por exemplo, um sistema educacional nacional” (HALL, 2005, p. 49-50).

A identidade do sujeito também era vista como fixa, estável e coerente. O sujeito do Iluminismo era dotado de uma essência permanente, caracterizado como "um indivíduo totalmente centrado, unificado, dotado das capacidades de razão, de consciência e de ação" (HALL, 2005, p. 11). Entretanto, essa ideia de uma "identidade plenamente unificada, completamente segura e coerente é uma fantasia" (HALL, 2005, p. 13), uma estória criada por nós mesmos ou o que Hall denomina uma "narrativa do eu", desconstruída pela visão do sujeito pós-moderno, formado e transformado historicamente, a partir das relações estabelecidas culturalmente, dotado de diferentes identidades para diferentes momentos, não mais unificadas e coerentes.

Em oposição à visão unificada de cultura, Menezes de Souza (2010) traz uma crítica que vai além de uma concepção homogênea, estrutural, normatizadora, fixa e estática, uma vez que "de Certeau chama a atenção para o fato de que qualquer visão de cultura no singular é fruto de um desejo pelo controle social da heterogeneidade que constitui qualquer comunidade"

\footnotetext{
3 [...] monolingualism is a recent invention even in the West: "Monolingualism, now usually considered the unmarked condition by members of the dominant linguistic group in modern nation-states, was in all likelihood less prevalent before the rise of the nation-state gave special sanction to it" (p. 438). The diverse languages and multilingual encounters in Western communities have been ignored in scholarship and, in some cases, socially suppressed.
} 
(MENEZES DE SOUZA, 2010, p. 295), concebendo, então, uma ideia de cultura heterogênea, criadora, dinâmica, aberta e emergente.

Já em oposição às concepções de língua enquanto sistema fixo de sentidos, Hall (1997) menciona um entendimento desse conceito como construção e prática, reconhecendo o caráter social da linguagem e a multiplicidade de sentidos. Tal concepção não nega o mundo material, mas entende que não é ele que produz sentidos por si só, mas sim:

[...] o sistema linguístico ou qualquer sistema que estejamos usando para representar nossos conceitos. São atores sociais que usam sistemas conceituais de sua cultura e os sistemas linguístico e outros sistemas representacionais para construir sentido, para fazer o mundo significativo e para comunicar aos outros sobre o mundo de forma significativa (HALL, 1997, p. 25). ${ }^{4}$

Do mesmo modo, uma visão de língua dinâmica, emergente e performativa, para além da estrutura, do sistema e da norma é também trazida por Menezes de Souza (2010). Importa aqui salientar que tanto na cultura quanto na língua há a ação de duas forças: a normatizadora e a desnormatizadora. Enquanto a primeira "garante um mínimo de elementos em comum, e portanto, a compreensibilidade" (MENEZES DE SOUZA, 2010, p. 298), a segunda permite "a diferença e a variabilidade, introduzindo o novo e a transformação" (MENEZES DE SOUZA, 2010, p. 298). Sendo assim, o problema reside na tentativa de interromper o dinamismo dessa relação, fixando apenas na força normatizadora, característica de uma concepção estruturalista de língua.

Canagarajah (2017) também se distancia de uma visão estruturalista de língua, que considera a língua como uma entidade abstrata, uma estrutura fechada, separada de outras modalidades de comunicação e independente do contexto espaço-temporal (história, geografia, política, cultura e sociedade), impondo ordem, controle e normatividade sobre a complexidade e a materialidade da vida social. Em algumas abordagens, o contex to era entendido como algo que enquadra a língua, como o estado-nação ou a comunidade de fala, conceitos que, segundo Canagarajah $(2017$, p. 2), “territorializou e essencializou a língua, conferindo sua posse a determinados grupos de falantes e/ou suas terras"

O autor apresenta então um entendimento de língua enquanto prática translíngue, na qual explora aspectos da língua antes ignorados pelo estruturalismo a fim de abarcar a complexidade linguística percebida por uma perspectiva pós-estruturalista.

\footnotetext{
${ }^{4}$ [...] the language system or whatever system we are using to represent our concepts. It is social actors who use the conceptual systems of their culture and the linguistic and other representational systems to construct meaning, to make the world meaningful and to communicate about that world meaningfully to others.

5 [...] territorialized and essentialized language, providing ownership to certain groups of speakers and/or their lands.
} 
O espaço, antes negligenciado por uma visão estruturalista de língua, é agora considerado como um elemento essencial na situação comunicativa, dotado de agência e capaz de influenciar outros elementos da interação, inclusive o humano. Nesse sentido, todas as dimensões da interação são consideradas como interconectadas, uma dependente da outra na co-construção dos significados. Em uma perspectiva estruturalista apenas a modalidade verbal da língua é capaz de produzir significado, ou mesmo quando outras modalidades são consideradas, elas são vistas como suplementares aos recursos estritamente linguísticos. Já em uma perspectiva espacial pós-estruturalista, nenhum dos recursos é definido como mais importante na produção de significados anteriormente à interação e nenhum deles pode ser tratado separadamente. Para além dos recursos linguísticos gramaticais, outras semioses emergentes das interações são consideradas como produtoras de sentido. Recursos não-verbais, dotados de agência, também moldam o uso da língua e mesmo a cognição humana.

Uma relação mais orgânica entre mente, corpo e mundo na construção de significados também é considerada por essa perspectiva espacial pós-estruturalista, implicando que não é possível se preparar para a situação comunicativa dotado de gramáticas e códigos. Em vez disso, "é necessário o alinhamento de diversos recursos e condições contextuais para produzir sentido" (CANAGARAJAH, 2017, p. 19) ${ }^{6}$.

Essas diferentes posturas diante do estudo da linguagem nos levam a uma posição que percebe a heterogeneidade como constitutiva da língua, da cultura e da identidade do sujeito, considerando qualquer visão homogênea desses conceitos como fruto de um esforço de unificação e de supressão da diferença, através do discurso e também da violência.

Partimos, portanto, de um entendimento de língua como construção e prática social, que a compreende como fluida e dinâmica, produzindo significados situados e emergentes. A língua, dessa forma, deixa de ser entendida em termos de estruturas e significados fixos e homogêneos para tornar-se uma prática discursiva, em que os sentidos não são únicos, mas sim múltiplos, construídos e situados no contexto sócio-histórico.

Trazendo essa discussão para o caso da língua inglesa e seu status na sociedade contemporânea globalizada, a ideia de uma língua homogênea, pertencente a territórios delimitados e vinculada a uma cultura, também homogênea, torna-se ainda mais inconsistente. Pelo alcance global que o inglês possui hoje, ele adquiriu a função de língua de comunicação internacional, tornando-se, conforme Siqueira (2011), um idioma desterritorializado. Nesse papel de língua internacional, a língua inglesa não pertence mais a um grupo específico de

\footnotetext{
${ }^{6}$ One has to undertake the alignment of diverse resources and contextual conditions for meaning.
} 
falantes nativos nem a uma nação (SIQUEIRA, 2011). Além disso, ao entrar em contato com outras experiências linguísticas locais, torna-se "um exemplo da mestiçagem linguística que marca os nossos dias pós-modernos" (RAJAGOPALAN, 2010, p. 23 apud SIQUEIRA, 2011, p. 90).

$\mathrm{Na}$ área de Aquisição de Segunda Língua (ASL), embora se reconheça, por um lado, a influência da dimensão social e contextual da língua, da aquisição e da aprendizagem e, por outro lado, da dimensão individual da língua e seus processos mentais e cognitivos, autores como Firth e Wagner (1997), Canagarajah e Wurr (2011) e participantes do The Douglas Fir Group (2016) identificam uma predominância dessa última tendência. Para Firth e Wagner (1997, p. 288), essa predominância:

[...] teve o efeito de reduzir as identidades sociais a 'sujeitos', ou a uma distinção binária entre nativos e não-nativos/aprendizes. Dá primazia à prática de pesquisa de codificar, quantificar os dados e replicar os resultados. Prioriza explicações de fenômenos em termos de processos cognitivos subjacentes em vez de descrições de fenômenos. Atribui preferência à (manipulação do pesquisador de) cenários experimentais em vez dos naturais. Endossa a busca por processos universais e basilares da língua em vez dos particulares e locais. Vê a comunicação como um processo de transferência de informação da mente de um indivíduo para a de outro. [...] No melhor dos casos marginaliza, e no pior deles ignora, as dimensões sociais e contextuais da língua. ${ }^{7}$

É possível afirmar que a linha cognitiva majoritariamente adotada nesse campo de estudos reflete pressupostos acerca da língua embasados em concepções estruturalistas e homogeneizantes, e entende a língua em seu caráter funcional de instrumento de comunicação, como apresentamos no início do capítulo. Esses mesmos autores defendem uma redefinição de certas categorias tradicionalmente presentes no campo, como forma de abarcar a realidade multilíngue que vivenciamos hoje. Dessa forma, propõe-se a revisão de determinados termos e a superação de alguns binarismos. A cognição se alinha ao contexto; modelos positivistas lineares tornam-se sistemas complexos, abertos e dinâmicos; a noção de comunidades de fala homogêneas se torna heterogênea, assim como monolinguismo e multilinguismo; em vez de correção linguística se fala em negociação de sentidos; de fixa, a língua passa a ser vista como fluida (CANAGARAJAH; WURR, 2011); a gramática em vez de pré-definida, passa a emergir da interação; as ideias de língua alvo e proficiência linguística são substituídas pela de

\footnotetext{
${ }^{7}[. .$.$] has had the effect of reducing social identities to 'subjects', or at best to a binary distinction between native$ and nonnatives/learners. It gives preeminence to the research practice of coding, quantifying data, and replicating results. It prioritizes explanations of phenomena in terms of underlying cognitive processes over descriptions of phenomena. It assigns preference to (researcher manipulation of) experimental settings rather than naturalistic ones. It endorses the search for the universal and underlying features of language processes rather than the particular and the local. It views communication as a process of information transfer from one individual's head to another's. [...] At best if marginalises, and at worst ignores, the social and the contextual dimensions of language (p. 288).
} 
repertórios linguísticos; as noções de língua adicional e segunda língua são questionadas (THE DOUGLAS FIR GROUP, 2016), assim como as de aprendiz e usuário, nativo e não-nativo (FIRTH; WAGNER, 1997; CANAGARAJAH; WURR, 2011).

A respeito desse último par binário, nativo e não-nativo, Firth e Wagner (1997) tecem algumas considerações a respeito do status adquirido pelo falante nativo nas pesquisas em ASL. Dentre elas, afirmam que os dados coletados de falantes nativos são vistos como a base de comparação para os dados de falantes não-nativos. Mesmo quando não há a presença de nativos na interação, é a partir deles e de suas características que se define o que é apropriado ou válido em termos linguísticos. Além disso, criticam a hierarquia entre essas duas categorias, sendo o falante não-nativo visto como subordinado do nativo. Os autores questionam ainda o próprio uso dessas nomenclaturas, uma vez que levam à homogeneização de cada grupo, como se fossem entidades estáticas. A interação entre esses falantes é considerada inerentemente problemática, sendo o não-nativo visto como o causador dos problemas na comunicação. Criticam também o fato de as pesquisas desconsiderarem todas as outras identidades sociais de seus participantes, como se apenas as identidades de nativo ou não-nativo bastassem. Também ressaltam o caráter monolíngue da pesquisa em ASL, uma vez que os nativos monolíngues são numericamente e, por consequência, politicamente dominantes, ignorando a realidade multilíngue de diversas comunidades e o fato de que, no caso do inglês, seu caráter internacional faz com que haja mais interações entre falantes não-nativos que usam o inglês enquanto língua franca.

O modo como concebemos a língua, que procuramos explicar até o momento, articulase aos estudos da Linguística Aplicada Crítica (LAC). Embora Freitas e Pessoa (2012) considerem a publicação de Critical applied linguistics: a critical introduction, de Pennycook, em 2001 como o início dos estudos nesse campo, os autores já identificam o surgimento de uma abordagem crítica na Linguística Aplicada em trabalhos anteriores do autor. Em 1990, Pennycook denuncia a manutenção das desigualdades sociais através da aprendizagem de línguas e conclama os linguistas aplicados a refletir sobre o conhecimento que produzem e como eles contribuem para a manutenção da hegemonia. Para isso, ele propõe um rompimento dos "modos de investigação que sejam associais, apolíticos e a-históricos" (PENNYCOOK, 1990, p. 43 apud FREITAS; PESSOA, 2012, p. 230).

Em 1998, Pennycook estabelece uma relação entre a língua inglesa e as ideologias coloniais, dando continuidade a essa expansão crítica da LA. Segundo Freitas e Pessoa (2012), o autor defende o uso do inglês como forma de resistência na criação de contra-discursos, em vez de rejeitá-lo por ser a língua do opressor. 
Sobre o trabalho de Pennycook publicado em 1999, os autores enfatizam a questão do poder, do acesso, da desigualdade e da resistência no ensino crítico de língua inglesa. $\mathrm{O}$ linguista advoga pela politização do ensino do idioma, "o que não significa simplesmente adotar uma postura de esquerda, mas questionar as implicações éticas e políticas do nosso trabalho como professores(as) de inglês nos contextos micro e macro onde atuamos" (FREITAS; PESSOA, 2012, p. 231).

Os autores compreendem que a LAC se consolida como campo de pesquisa em 2001 com Pennycook e a publicação de Critical applied linguistics: a critical introduction. Nas palavras de Freitas e Pessoa (2012, p. 231-232, grifos no original):

O autor aposta na visão de LAC como prática problematizadora, que, ao se basear em perspectivas pós-estruturalistas, pós-modernas e pós-coloniais, concebe a língua como sendo inerentemente política e o poder como estando sempre relacionado a questões de classe, raça, gênero, etnia, sexualidade etc. [...] Na LAC, a língua não desempenha uma função de modelo, mas de prática social. Uma vez que o conhecimento se torna possível por meio da língua, tanto o conhecimento quanto a língua são definidos, então, como meios que nos possibilitam compreender e transformar as relações sociais.

Importa ressaltar que a LAC não é vista como um método ou uma técnica de análise da linguagem, mas como "uma abordagem mutável e dinâmica para as questões da linguagem em contextos múltiplos" (PENNYCOOK, 2006, p. 67) e, embora se relacione a outros campos do conhecimento, não é compreendida como uma forma de conhecimento interdisciplinar, mas sim como "uma forma de antidisciplina ou conhecimento transgressivo, como um modo de pensar e fazer sempre problematizador" (PENNYCOOK, 2006, p. 67).

A noção de língua como prática social, mencionada acima por Freitas e Pessoa (2012), é entendida pelo linguista aplicado como uma atividade, aquilo que as pessoas fazem, distanciando-se da ideia de língua como sistema. Nas palavras do autor:

[...] prática é o que as pessoas fazem, o que te oferece uma maneira de pensar na língua como uma atividade, e te distancia de uma maneira de pensar na língua como um sistema. E não é que a gramática não importa, mas se você começa com a ideia de língua como prática, você pode começar a dizer: "Não, na verdade a língua faz coisas". Língua é o que fazemos e o sistema que chamamos de gramática emerge disso. Não é a definição pré-existente do que uma língua é. [...] É basicamente dizer que as pessoas fazem coisas repetidamente de formas parecidas e isso nos dá a impressão de que é uma espécie de sistema fixo ou sistemático, mas ele sempre pode mudar (PENNYCOOK; PESSOA; SILVESTRE, 2016, p. 621). ${ }^{8}$

\footnotetext{
${ }^{8}$ [...] practice is what people do, so that gives you a grounded way of thinking about language as an activity, and that moves you away from thinking about language as a system. And it's not that grammar doesn't matter, but if you start the idea of language as a practice, you can start to say: "No, actually, language does stuff." Language is the stuff we do and the system that we call grammar comes out of that. It's not the preexisting definition of what a language is. [...] It's basically saying people do stuff over and over in similar ways and that gives us the impression that it's sort of fixed or systematic, but it can always change.
} 
É possível afirmar que a LAC se diferencia da Linguística Aplicada (LA) no sentido em que esta última, mesmo interessada na linguagem e sua prática, mostra-se alheia às questões políticas, voltando-se prioritariamente para questões cognitivas, discursivas, pedagógicas ou linguísticas. Já para a LAC, o uso da linguagem é sempre relacionado a poder e privilégio, tornando a LA “mais responsável politicamente" (PENNYCOOK, 2001 apud SOARES; ZAIDAN, 2015, p. 872).

É esse olhar problematizador da LAC que buscamos lançar ao conceito de ILF e às propostas curriculares aqui analisadas, relacionando-os a questões políticas, sociais e culturais mais amplas, permeadas por poder e privilégio no uso da língua.

Assumir tal postura nos faz ainda reconhecer a permanência das relações de colonialidade nos usos e estudos da língua inglesa, uma vez que o discurso da falta e da deficiência, característico da colonialidade, ainda é atribuído aos usuários não-nativos do idioma, como é o caso, por exemplo, dos brasileiros. Perceber a continuidade dessa relação de colonialidade nos aproxima das produções dos estudos decoloniais, que se preocupam com os hábitos dessa herança colonial que ainda carregamos, fazendo com que diferentes subjetividades, conhecimentos, visões de mundo e de vida sejam negadas e distorcidas e o pensamento moderno ocidental seja o centro de tudo que é considerado válido, aceito ou mesmo possível. Para Sousa Santos (2007), esse é um pensamento abissal, que divide a realidade por meio de linhas, estabelecendo uma distinção entre dois universos: um visível, "este lado da linha", e um invisível, "o outro lado da linha". Este último torna-se e é produzido como inexistente. Nas palavras do autor:

Inexistência significa não existir sob qualquer modo de ser relevante ou compreensível. Tudo aquilo que é produzido como inexistente é excluído de forma radical porque permanece exterior ao universo que a própria concepção de inclusão considera como o "outro". A característica fundamental do pensamento abissal é a impossibilidade da co-presença dos dois lados da linha. O universo "deste lado da linha" só prevalece na medida em que esgota o campo da realidade relevante: para além da linha há apenas inexistência, invisibilidade e ausência não-dialética (SOUSA SANTOS, 2007, p. 71).

Segundo Walsh (2018) ${ }^{9}$, a América Latina foi onde teve início tanto a colonialidade do poder quanto a decolonialidade, sendo o primeiro entendido como "um sistema de classificação social baseado na ideia de raça, de 'conquistadores' sobre 'conquistados', e sua fundação estrutural é ligada à Modernidade e ao capitalismo Eurocentrado"10 (MIGNOLO; WALSH,

\footnotetext{
${ }^{9}$ Uma vez que a obra em questão é dividida em duas partes, sendo que uma delas é escrita por Walsh e outra por Mignolo, as citações a essa obra (MIGNOLO; WALSH, 2018) serão feitas pela menção do nome de cada autor de forma separada, correspondente à parte da obra escrita por cada um deles.

10 [...] a system of social classification based on the idea of race, of 'conquerors' over 'conquered', and its structural foundation tied to modernity and Eurocentered capitalism.
} 
2018, p. 16) e o segundo como "um componente parte das lutas (trans)locais, movimentos e ações para resistir e recusar os legados e as relações em curso e padrões de poder estabelecidos pelo colonialismo interno e externo [...] e os designs globais do mundo moderno/colonial"11 (MIGNOLO; WALSH, 2018, p. 16).

Para entender mais profundamente a decolonialidade, é importante distinguir entre colonialidade e colonialismo. Segundo Maldonado-Torres (2007), enquanto o colonialismo se refere a uma dominação política e econômica de uma nação sobre outra, a colonialidade (QUIJANO, 2007) é entendida como o resultado do colonialismo moderno, que vai além das relações políticas e econômicas e sobrevive ao fim do colonialismo. De forma semelhante a Mignolo e Walsh (2018), Maldonado-Torres (2007, p. 131) compreende a colonialidade como:

[...] a forma como o trabalho, o conhecimento, a autoridade e as relações intersubjetivas se articulam entre si, através do mercado capitalista mundial e da ideia de raça. [...] Ela se mantém viva nos livros didáticos, no critério para um bom trabalho acadêmico, na cultura, no senso comum, na autoimagem dos povos, nas aspirações do sujeitos, e em muitos outros aspectos da nossa experiência moderna. De certo modo, respiramos a colonialidade na modernidade cotidianamente. ${ }^{12}$

Os estudiosos do pensamento decolonial afirmam, portanto, que a descolonização se limitou à independência jurídico-política das colônias, enquanto as relações de colonialidade permaneceram intactas, manifestando-se através da colonialidade do poder, do saber e do ser. Embora estejam relacionadas umas às outras, podemos entender essas noções separadamente. A colonialidade do poder se refere a "inter-relação entre formas modernas de exploração e dominação"13 (MALDONADO-TORRES, 2007, p. 129-130), que, segundo Walsh (2012), se baseia na categoria de raça para estabelecer uma classificação social mundial nas relações de trabalho, colocando o homem branco europeu em uma posição superior à dos índios e negros. Já a colonialidade do saber "tem a ver com o papel da epistemologia e as funções gerais da produção de conhecimento na reprodução dos regimes de pensamento coloniais"14 (MALDONADO-TORRES, 2007, p. 129-130). Novamente o pensamento, a razão e o conhecimento do homem branco europeu são colocados no centro, enquanto outros

\footnotetext{
11 [...] a component part of (trans)local struggles, movements, and actions to resist and refuse the legacies and ongoing relations and patterns of power established by external and internal colonialism [...] and the global designs of the modern/colonial world.

12 [...] la forma como el trabajo, el conocimiento, la autoridad y las relaciones intersubjetivas se articulan entre sí, a través del mercado capitalista mundial y de la idea de raza. [...] La misma se mantiene viva en manuales de aprendizaje, en el criterio para el buen trabajo académico, en la cultura, el sentido común, en la auto-imagen de los pueblos, en las aspiraciones de los sujetos, y en tantos otros aspectos de nuestra experiencia moderna. En un sentido, respiramos la colonialidad en la modernidad cotidianamente.

13 [...] interrelación entre formas modernas de explotación y dominación.

14 [...] tiene que ver con el rol de la epistemología y las tareas generales de la producción del conocimiento en la reproducción de regímenes de pensamiento coloniales.
} 
conhecimentos e racionalidades epistêmicas são descartadas, silenciadas e invisibilizadas (WALSH, 2012). Por fim, “a invisibilidade e a desumanização são as expressões primárias da colonialidade do ser"15 (MALDONADO-TORRES, 2007, p. 150-151), de modo que, com base na categoria racial, a própria humanidade do sujeito colonizado é colocada em dúvida, afastando-os da modernidade, da razão e das faculdades cognitivas (WALSH, 2012, p. 68).

De uma perspectiva decolonial, reconhece-se também a relação entre modernidade e colonialidade, uma vez que, segundo Mignolo e Walsh (2018), a primeira não existe sem a segunda, estando íntima, intrínseca e explicitamente entrelaçadas. Maldonado-Torres (2007) também enfatiza essa relação, definindo a colonialidade como o lado obscuro constitutivo da modernidade.

A colonialidade cria uma rede estrutural de relações de poder, afetando-nos enquanto sujeitos modernos e influenciando diversas esferas da nossa existência, criando hierarquias de classe, de gênero, étnico-raciais, sexuais, epistêmicas, espirituais, estéticas, pedagógicas e linguísticas (MONTOYA; BUSSO, 2007), ao que os estudiosos chamam de heterarquias, ou seja, a rede articulada de várias formas de poder (CASTRO-GÓMEZ; GROSFOGUEL, 2007). Como as hierarquias estão enredadas umas às outras e exercem influência mútua entre si, não é suficiente combater apenas um problema, como sugere uma perspectiva marxista quando se limita à questão econômica com as hierarquias de classe. Ao esquecermos das outras possibilidades de estabelecimento da ordem do poder, acabamos por construir as mesmas hierarquias e reproduzir o mesmo sistema social europeu/norte-americano capitalista/patriarcal moderno/colonial (MONTOYA; BUSSO, 2007; CASTRO-GÓMEZ; GROSFOGUEL, 2007). Reconhecendo, portanto, a permanência das relações coloniais de poder mesmo com o fim dos processos de colonização, a decolonialidade tem como objetivo atingir justamente esse sistema heterárquico de poder, desfazendo, desobedecendo e desconectando-se dessa matriz colonial para que outros modos de pensar, sentir, acreditar, fazer e viver sejam possíveis (MIGNOLO; WALSH, 2018). De forma similar, Sousa Santos (2007) afirma que a decolonialidade implica o reconhecimento e a tentativa de desfazer essa racionalidade ocidental "deste lado da linha" como única perspectiva possível de existência, análise e pensamento, tornando visíveis outras formas de pensar, fazer, conhecer, sentir e ser, ou seja, as formas "do outro lado da linha" produzidas como invisíveis. Para isso, é preciso um pensamento pós-abissal, que:

[...] é um pensamento não-derivativo, pois envolve uma ruptura radical com as formas de pensamento e ação da modernidade ocidental. No nosso tempo, pensar em termos não-derivativos significa pensar a partir da perspectiva do outro lado da linha,

\footnotetext{
${ }^{15}$ La invisibilidad y la deshumanización son las expresiones primarias de la colonialidad del ser.
} 
precisamente porque ele é o domínio do impensável no Ocidente moderno (SOUSA SANTOS, 2007, p. 85).

Para Maldonado-Torres (2007), a decolonialidade representa uma mudança de perspectiva e atitude em relação às formas de conhecimento dos sujeitos colonizados e um projeto de transformação dos pressupostos e implicações da modernidade assumido por uma variedade de sujeitos em diálogo. Mignolo e Walsh (2018) entendem que a decolonialidade não é um ponto de chegada estático, mas sim um processo dinâmico. Por isso, falar de uma atitude decolonial, como proposto por Maldonado-Torres, talvez faça mais sentido, o que significa assumir diferentes perspectivas, principalmente aquelas que foram repetidamente suprimidas e produzidas como inexistentes.

Embora seja possível falar de uma diversidade de projetos decoloniais, o ponto em comum entre eles é o que Mignolo (2009) chama de ferida colonial, ou seja, "o fato de que regiões e pessoas ao redor do mundo foram classificadas como subdesenvolvidas econômica e mentalmente"16 (MIGNOLO, 2009, p. 3). Ainda para o autor, o pensamento decolonial assume como tarefa desvelar os silêncios epistêmicos da epistemologia ocidental e afirmar os direitos epistêmicos daqueles que foram racialmente desvalorizados. Para isso, defende que a transformação deve partir de atos de desobediência epistêmica.

Portanto, pautar-se nos estudos da decolonialidade no entendimento do Inglês como Língua Franca significa legitimar os usos não hegemônicos da língua, dando lugar às vozes antes silenciadas, em oposição ao caráter normativo eurocêntrico há muito visto como referência no campo, questionando as próprias categorias subjacentes ao estudo da língua e à própria forma de construir conhecimento. Essa perspectiva questiona os conceitos ocidentais modernos de neutralidade, objetividade, distância, teoria, conhecimento, pesquisa e pensamento acadêmico (MIGNOLO; WALSH, 2018), problematizando a concepção cartesiana de conhecimento que, segundo Garcés (2007, p. 225-226), criou a ilusão de que o conhecimento é deslocalizado e desincorporado, ao que os pensadores decoloniais denominam de ego-política do conhecimento:

Na ego-política do conhecimento, o sujeito da enunciação fica apagado, escondido, camuflado no que o filósofo colombiano Santiago Castro-Gomez chamou de "hybris do ponto zero (Castro-Gomez, 2005). Trata-se, então, de uma filosofia na qual o sujeito epistêmico não tem sexualidade, gênero, etnicidade, raça, classe, espiritualidade, língua, nem localização epistêmica em nenhuma relação de poder e produz a verdade a partir de um monólogo interior consigo mesmo, sem relação com ninguém fora de si. Em outras palavras, trata-se de uma filosofia surda, sem rosto e

\footnotetext{
${ }^{16}[\ldots]$ the fact that regions and people around the world have been classified as underdeveloped economically and mentally.
} 
sem força de gravidade. O sujeito sem rosto flutua pelos céus sem ser determinado por nada nem por ninguém (GROSFOGUEL, 2007, p. 64). ${ }^{17}$

Como menciona Grosfoguel (2007), essa pretensão da ciência moderna de observar o mundo como se estivesse fora dele, tal como se ocupasse o lugar de Deus, um ponto zero de observação, um posto de vista acima de todos os outros, é chamada de hybris do ponto zero por Castro-Gómez (2007). Embora tenha essa intenção, a ciência não consegue equiparar-se a Deus, cometendo o pecado grego da hybris, ou seja, do excesso: seres humanos que querem ser como deuses, embora não tenham essa capacidade. Já de uma perspectiva decolonial, entendemos que o conhecimento é sempre localizado e incorporado, pois parte sempre de um ponto específico de observação de um sujeito concreto dotado de um corpo marcado pelas suas condições histórico-sociais específicas, sem a pretensão da neutralidade e da objetividade (CASTRO-GÓMEZ; GROSFOGUEL, 2007, p. 21). Nas palavras de Castro-Gómez (2007, p. 88), "descolonizar o conhecimento significa descer do ponto zero e evidenciar o lugar a partir do qual se produz esse conhecimento" ${ }^{18}$. Sendo assim, as lentes decoloniais nos estudos de ILF nos fazem olhar para os sujeitos que produzem conhecimento sobre o tema e de que lugar enunciam. Além disso, no que se refere à pesquisa aqui apresentada, partimos de um ponto de vista localizado e incorporado, de uma pesquisadora inscrita em seu contexto sócio-histórico que também é falante brasileira de inglês e professora desse idioma na rede privada de ensino, o que faz com que as perspectivas de análise aqui desenvolvidas sejam permeadas também por essas identidades.

É importante aqui retomar a menção aos estudos da pós-modernidade nos quais nos apoiamos, uma vez que, para Grosfoguel (2007, p. 74), “a pós-modernidade é uma crítica eurocêntrica ao eurocentrismo. Reproduz todos os problemas da modernidade/colonialidade"19. Em vez de descartar, com isso, as contribuições pós-modernas, compreendemos que, como esclarece Maldonado-Torres (2007, p. 159-160), é possível pautar-se nelas seguindo uma direção descolonizadora:

Quer dizer que o pensamento decolonial pode ter elementos modernos e pósmodernos, mas estes não são os únicos nem os mais centrais e constantes. Por outro

\footnotetext{
${ }^{17}$ En la ego-política del conocimiento el sujeto de enunciación queda borrado, escondido, camuflado en lo que el filósofo colombiano Santiago Castro-Gomez ha llamado la "hybris del punto cero" (Castro-Gomez, 2005). Se trata, entonces, de una filosofía donde el sujeto epistémico no tiene sexualidad, género, etnicidad, raza, clase, espiritualidad, lengua, ni localización epistémica en ninguna relación de poder, y produce la verdad desde un monólogo interior consigo mismo, sin relación con nadie fuera de sí. Es decir, se trata de una filosofía sorda, sin rostro y sin fuerza de gravedad. El sujeto sin rostro flota por los cielos sin ser determinado por nada ni por nadie. 18 Decolonizar el conocimiento significa descender del punto cero y hacer evidente el lugar desde el cual se produce ese conocimiento.

19 La posmodernidad es una crítica eurocéntrica al eurocentrismo. Reproduce todos los problemas de la modernidad/colonialidad.
} 
lado, é necessário reconhecer que algumas ideias da modernidade e da pósmodernidade podem remeter a contribuições do pensamento decolonial, o que quer dizer que há elementos no interior delas para explorá-las em uma direção descolonizadora. ${ }^{20}$

Para isso, é necessário reconhecer as influências e as fontes desse pensamento, questionando-as a partir das dimensões decoloniais. É claro que, na condição de sujeitos afetados pela modernidade/colonialidade e partindo da impossibilidade de se colocar com neutralidade, distanciamento e objetividade diante da pesquisa, é possível que categorias modernas perpassem pela análise aqui desenvolvida.

É, portanto, a partir dessa perspectiva decolonial e crítica que este trabalho se propõe a olhar para esses novos usos e funções da língua inglesa como idioma desterritorializado, para as políticas educacionais brasileiras voltadas para o ensino dessa língua e também para as questões no entorno dos debates e estudos sobre ILF.

\footnotetext{
${ }^{20}$ Lo que quiere decir es que el pensamiento de-colonial puede tener elementos modernos o posmodernos, pero estos no son los únicos ni los más centrales o constantes. Por otro lado, hay que reconocer también que algunas ideas en la modernidad y la posmodernidad pueden remitirse a contribuciones del pensamiento decolonial, lo que quiere decir que hay elementos en el interior de las mismas para explotarlas en una dirección de-colonizadora.
} 


\title{
CAPÍTULO 2 - INGLÊS COMO LÍNGUA FRANCA: SENTIDOS EM DISPUTA
}

\author{
LÍNGUA UNIVERSAL
}

Meu pai estava assistindo um desenho que ele via na infância, em francês, e chamou a Fê pra

ver com ele.

- Olha, Fê, o vovô via esse desenho na sua idade.

- O que ele está falando vovô? Não entendo nada.

- É porque está em francês.

Depois de um tempo, o menino do desenho solta uma gargalhada e a Fernanda diz:

- Olha, vovô!! A risada está em português. Eu consegui entender!

(Fernanda, 4 anos)

@frasesdecrianca

Este capítulo tem como objetivo investigar as questões epistemológicas e ontológicas que embasam o conceito de ILF e esse campo de estudos. Apresentamos inicialmente diferentes acrônimos presentes nos estudos da linguagem que tentam abarcar os usos da língua inglesa no mundo, enfatizando os aspectos que os diferem ou os aproximam de ILF. Em seguida, fazemos um estado-da-arte do conceito que tematiza este trabalho, observando o modo como o conceito é definido por Jennifer Jenkins (2000, 2005, 2006a, 2006b, 2015, 2017) e Barbara Seidlhofer (1999, 2001, 2005, 2009) desde o início dos estudos nessa área, apontando a multiplicidade de sentidos atribuídos ao termo e tentando identificar que concepções de língua e conhecimento embasam esses estudos. Prosseguimos apresentando outros autores no cenário internacional que se dedicam ao tema para então analisarmos como o conceito tem sido apropriado por pesquisadores brasileiros. Partindo de uma perspectiva decolonial, buscamos evidenciar de que modo a colonialidade se faz presente nesse campo de pesquisa, a quem pertencem as vozes que enunciam sobre o tema e de que lugar do mundo elas partem.

\subsection{Para além do ILF: as diferentes terminologias circulantes nos estudos da linguagem}

Como o nosso estado-da-arte do conceito de ILF mostrará a seguir, até se constituir como um campo de estudos autônomo, as pesquisas nessa área apoiavam-se em outros paradigmas de estudo do inglês. Inicialmente, até mesmo a nomenclatura alternava-se entre ILF e Inglês como Língua Internacional (ILI). Além disso, muitos dos princípios que guiaram as 
primeiras pesquisas se pautavam nos estudos em World Englishes (WE). Antes de nos dedicarmos especificamente ao termo que tematiza este trabalho, consideramos importante entender de que maneira cada um desses paradigmas contribuiu para a formação dos estudos em ILF. Com esse objetivo, nos voltamos agora à tarefa de tentar esclarecer o sentido de cada um desses acrônimos (ILI e WE) e também de outros termos atualmente circulantes que tentam abarcar as novas realidades no uso do inglês, tais quais Inglês como Língua Global (ILG), Lingua Franca English (LFE) e Inglês como Língua Adicional (ILA).

Todos os acrônimos supracitados emergem como forma de oposição a um paradigma que dominou, e ainda domina, o campo do ensino de língua inglesa por muito tempo, o do Inglês como Língua Estrangeira (ILE). Jordão (2014) afirma que o termo se refere a um contexto de aprendizagem da língua cujo objetivo é a comunicação com falantes nativos do idioma, o que coloca os usuários não-nativos em uma posição subalterna em relação àqueles que a usam como primeira língua, acarretando processos de reprodução da cultura ligada aos países que dariam origem ao ILE. Dentro desse paradigma, portanto, os falantes nativos do idioma são vistos como referência para o que é aceitável ou não no uso da língua, enquanto os outros usuários são colocados sempre na posição da falta e da inferioridade, que devem apenas reproduzir as normas daqueles que são vistos como os "donos" do idioma.

Para o status global que o inglês adquiriu na sociedade globalizada, o paradigma do ILE e aquilo que ele implica deixou de ser o mais adequado para compreender o idioma e pensar sobre o seu ensino. Segundo Crystal (2003), esse status não resulta da quantidade de falantes nem de características intrínsecas da língua, mas sim do poder daqueles que a usam, principalmente político e militar, o que faz com que ela adquira um papel ou função especial em diversos países. Um dos modos de fazer isso é torná-la língua oficial do país, usada como meio de comunicação pelo governo, pela mídia, na legislação e na educação, como é o caso do inglês em países como a Nigéria e a Índia. Mesmo quando a língua não é adotada oficialmente, o país pode privilegiá-la no ensino como uma língua estrangeira, como o inglês é hoje priorizado em países como o Brasil. O status global de uma língua advém, portanto, de seu uso enquanto primeira língua, segunda língua e língua estrangeira, que é a atual situação do inglês, resultando no acrônimo Inglês como Língua Global (ILG).

Quanto ao WE, o ILI e o ILF, Canagarajah (2013) estabelece uma distinção entre eles, em oposição ao que ele propõe como Lingua Franca English (LFE), ou o inglês entendido com uma prática translíngue. Além de diferenças específicas entre cada um, o autor aponta que enquanto o foco desses paradigmas recai principalmente sobre a forma e variantes linguísticas, na prática translíngue a atenção é voltada para a produção de significado. 
Acerca do modelo do WE, o autor admite sua importância no que diz respeito ao reconhecimento das variantes do inglês faladas nas ex-colônias britânicas como legítimas, dotadas de suas próprias normas, e não como uma versão deficiente do inglês. Sua crítica a esse paradigma refere-se à sua orientação monolíngue, uma vez que tem como objetivo identificar as variantes da língua nos limites do estado-nação, como se existisse uma clara delimitação entre elas e como se não houvesse heterogeneidade dentro desses limites. Além disso, apenas práticas já sedimentadas e estáveis adquirem o status de variante, excluindo os usos híbridos e transitórios que emergem nas práticas comunicativas. Interações entre falantes dos três círculos também são ignoradas, limitando a análise para variantes que ocorrem no interior de cada círculo. Para Canagarajah (2013), uma abordagem mais produtiva seria a tentativa de identificar os processos que embasam a construção dessas variantes, priorizando as práticas e tratando as variantes como emergentes.

Já a perspectiva do ILI coloca todas as variantes do inglês no mesmo patamar e considera que elas devem ser negociadas, e não uma imposta sobre a outra. Esse paradigma, diferentemente do WE, inclui interações entre estados-nação e mesmo no seu interior, mas ainda se assemelha ao modelo anterior uma vez que parte da premissa de variantes, mesmo que numa concepção mais abrangente, e se baseia na ideia de normas, principalmente gramaticais, para distinguir entre elas. Estudiosos dessa perspectiva também projetam que no futuro existirá uma variante neutra para contatos interlocais, a qual os falantes adotariam no lugar de suas próprias variantes. A necessidade de uma norma padrão acima de outras variantes para interações globais é criticada por Canagarajah (2013). Uma vez que um modelo linguístico é escolhido em detrimento de outras formas locais, negligencia-se a intenção inicial de não hierarquização entre as variantes. Além disso, essa ideia desconsidera que nas interações globais são as estratégias pragmáticas adotadas para produzir sentido que garantem a comunicação, mesmo que cada falante mantenha a sua própria variante.

No que se refere ao paradigma do ILF, segundo Canagarajah (2013), apesar de também proporem uma norma internacional que facilitasse a comunicação mundial em inglês, seus estudiosos não a consideram como neutra, como no ILI. Esse modelo seria construído a partir dos usos criativos dos falantes em oposição à norma dos falantes nativos. Para isso, seus precursores se engajaram na tarefa de reunir corpora dessas interações a fim de distinguir traços essenciais para mútua compreensão daqueles que não afetam a inteligibilidade e codificar o ILF. O foco na descrição recaiu principalmente nos aspectos fonológicos da língua, ignorando a pragmática, pois ela "não compreende um conjunto fechado de características para estudo, [e 
é] então menos restrito e manejável na pesquisa"21 (SEIDLHOFER, 2004, p. 217 apud CANAGARAJAH, 2013, p. 63).

$\mathrm{O}$ autor questiona essa abordagem nos mesmos termos que o ILI, especialmente por seu caráter monolítico. Evidências relatadas por outros pesquisadores, por outro lado, compreendem o uso da língua de contato como:

[...] 'uma variante em constante fluxo, envolvendo diferentes constelações de falantes de diversos ingleses individuais em cada interação' (Meierkord, 2004, p. 115). Em outras palavras, não há uma variante estável que marca a comunicação em zona de contato. Tal comunicação funciona porque os falantes estão preparados para adotar estratégias para co-construir normas in situ, e alcançar a inteligibilidade através (e não apesar de suas variantes e identidades locais ${ }^{22}$ (CANAGARAJAH, 2013, p. 64, ênfase no original).

Para a proposta do LFE de Canagarajah (2013), as estratégias de negociação na produção de sentidos são vistas como primordiais. Segundo o autor, as formas linguísticas são vistas como emergentes da situação comunicativa, e é a inteligibilidade que as torna válidas ou não. Além disso, ele afirma que, para essa perspectiva, a mútua compreensão pode ser alcançada sem a necessidade de normas linguísticas prévias em comum, sem uma competência linguística avançada nessas normas e sem uma comunidade de fala estável.

Por fim, o termo ILA vem sendo definido tanto como a situação de aprendizagem do inglês por imigrantes que residem em países cujo idioma oficial é o inglês, quanto uma língua acrescida à(s) língua(s) que já faz(em) parte do repertório do aluno, enfatizando seu caráter plurilíngue. Nesse último entendimento, "falar de uma língua adicional em vez de língua estrangeira enfatiza o convite para que os educandos (e os educadores) usem essas formas de expressão para participar na sua própria sociedade" (JORDÃO, 2014, p. 31-32, ênfase da autora).

Em consonância com Jordão (2014), argumentamos aqui que, a despeito do acrônimo utilizado, importa compreender as bases epistemológicas em que cada um deles se insere. Isso significa que o mesmo termo pode ter o seu sentido deslocado se for apropriado por diferentes epistemologias, como sugere a análise do conceito de ILF aqui desenvolvida, ou então acrônimos diferentes podem se apoiar em uma mesma base epistemológica, fazendo seus sentidos convergirem.

\footnotetext{
${ }^{21}[. .$.$] does not comprise a closed set of features for study," and that it is "thus less constrained and thus less$ manageable in research

22 [...] 'a variety in constant flux, involving different constellations of speakers of diverse individual Englishes in every single interaction' (Meierkord, 2004, $p$. 115). In other words, there is no stable variety that marks contact zone communication. Such communication works because speakers are prepared to adopt strategies to coconstruct norms in situ, and achieve intelligibility through (not despite) their local varieties and identities.
} 


\subsection{ILF no Norte Global: gênese e crítica}

Com o intuito de observar como o conceito de Inglês como Língua Franca vem se desenvolvendo desde o início desse campo de estudos, nos dedicamos aqui ao estado-da-arte do termo a partir de alguns trabalhos de Jennifer Jenkins (2000, 2005, 2006a, 2006b, 2015, 2017) e Barbara Seidlhofer (1999, 2001, 2005, 2009), as grandes precursoras no estudo do tema na Europa. Nos deteremos brevemente no percurso histórico do termo língua franca para então nos voltarmos ao acrônimo ILF, tecendo um diálogo entre as duas autoras supracitadas através da organização cronológica de alguns de seus trabalhos, o que nos permitirá identificar as semelhanças e diferenças nas definições de uma autora em relação à outra e também perceber as mudanças do conceito ao longo do tempo. Para além da história de ILF, pretendemos imprimir nesta análise um olhar crítico e decolonial, a fim de compreender não apenas as epistemologias subjacentes ao conceito de ILF, mas também as questões ontológicas, identificando de que maneira a colonialidade permeia esse campo de estudos. Se queremos questionar a base moderna/colonial do conhecimento, é necessário perguntar, como sugere Mignolo (2009), por quem, quando, por que e onde o conhecimento é gerado, deslocar a atenção do enunciado para a enunciação, de o que é conhecido para quem conhece, uma vez que quem conhece está implicado geográfica, política e corporalmente naquilo que se conhece. Para o que propomos neste trabalho, significa perguntar de quem são as vozes circulantes na produção científica de ILF, de onde elas vêm, e por que elas vêm de onde vêm. Constatar a própria gênese Europeia do conceito já é um indício dessa colonialidade que pretendemos apontar, questão que aprofundaremos ao longo do capítulo.

Voltando-nos agora para a história do termo língua franca, Brosch (2015) afirma que ele foi usado primeiramente como o nome de um pidgin, uma língua de contato com léxico e gramática simples desenvolvida espontaneamente para fins comerciais, falada na região do Mediterrâneo entre os séculos XIV e XIX por europeus, africanos e árabes, a fim de facilitar suas atividades econômicas.

Em decorrência do imperialismo europeu, observou-se a necessidade de uma denominação geral para línguas de contato que surgiam entre colonizadores e colonizados, que passaram a ser chamadas de língua franca, em referência ao nome do primeiro pidgin conhecido dos europeus. Com o tempo, o termo foi sendo utilizado como equivalente a língua veicular, aquela usada amplamente como meio de compreensão.

O uso contemporâneo do termo é comumente associado à língua inglesa, culminando no termo e no campo de estudos hoje denominado Inglês como Língua Franca, cujos primeiros trabalhos foram desenvolvidos por Jennifer Jenkins (2000) na área de pronúncia, seguidos pelos 
estudos de Barbara Seidlhofer (1999) sobre léxico e gramática da comunicação internacional em língua inglesa, sobre os quais discorremos a seguir.

Seidlhofer (1999) chama a atenção para a importância dos usos do inglês entre falantes não-nativos e questiona o pertencimento desse idioma aos falantes que o utilizam como primeira língua. Entretanto, o conceito de ILF não é ainda claramente definido, sendo ILI o termo usado pela autora. A menção a ILF se restringe ao grande volume de "interações entre não-nativos em inglês como língua franca" ${ }^{23}$ (SEIDLHOFER, 1999, p. 239), sugerindo um entendimento que considera apenas falantes não-nativos nas interações em contexto de língua franca.

Do mesmo modo, ao comentar sobre a realidade do inglês global, Jenkins (2000) afirma que o paradigma do ILE não mais expressa os objetivos de se aprender inglês hoje e ressalta a conotação negativa do termo "estrangeiro". A autora questiona a adequação do termo uma vez que, se o inglês é usado por pessoas do mundo todo, como pode ser um idioma estrangeiro? Por isso, Jenkins (2000, p. 11) propõe o uso do termo ILF e discorre sobre suas implicações:

ILF enfatiza o papel do inglês na comunicação entre falantes de diferentes L1, isto é,
a razão primária para se aprender inglês hoje; ele sugere a ideia de comunidade em
oposição ao estrangeiro; enfatiza que as pessoas têm algo em comum em vez das
diferenças; implica que 'misturar' línguas é aceitável (o que foi, na verdade, o que fez
a lingua franca original) e portanto não há nada inerentemente errado em reter certas
características da L1, como sotaque; e finalmente, o nome latino simbolicamente
remove a posse do inglês dos ingleses para ninguém e, na realidade, para todos. ${ }^{24}$

Aqui, Jenkins (2000) já oferece uma definição de ILF como a função do inglês na comunicação entre falantes de diferentes primeiras línguas, enfatizando as características próprias de uma língua internacional. Assim como em Seidlhofer (1999), há ainda uma oscilação entre os termos ILF e ILI, pois o uso do primeiro ainda não havia se tornado corrente. A autora prefere, então, optar pelo uso de ILI de maneira mais abrangente e restringir o uso de Língua Franca apenas para denominar o núcleo fonológico por ela proposto para a comunicação internacional, o Lingua Franca Core. Tal núcleo, resultado do seu projeto inicial restrito à pronúncia, buscou identificar características fonéticas e fonológicas consideradas cruciais para a inteligibilidade, com o intuito de incentivar os usuários da língua a aproximar sua fala dessas características quando necessário.

\footnotetext{
23 [...] non-native to non-native communication in English as a lingua franca.

${ }^{24}$ ELF emphasizes the role of English in communication between speakers from different L1s, i. e. the primary reason for learning English today; it suggests the idea of community as opposed to alienness; it emphasizes that people have something in common rather than their differences; it implies that 'mixing' languages is acceptable (which was, in fact, what the original lingua francas did) and thus that there is nothing inherently wrong in retaining certain characteristics of the L1, such as accent; finally, the Latin name symbolically removes the ownership of English from the Anglos both to no one and, in effect, to everyone.
} 
Já em Seidlhofer (2001), a autora propõe seu projeto de descrição e codificação do ILF, assim como já havia sido feito com variantes nativas e nativizadas do inglês através de corpora linguísticos. Para ela, ILF tem se espalhado "com uma grande quantidade de variação, mas com estabilidade suficiente para ser viável para comunicação em língua franca"25 (SEIDLHOFER, 2001, p. 138). Sendo assim, acreditava-se que, com a ajuda de corpora linguísticos, seria possível identificar as regularidades no uso da língua em contexto de língua franca, permitindo sua descrição, codificação e uso no ensino de inglês.

Tal empreendimento, segundo Seidlhofer (2001), contribuiria com o problema que ela chama de lacuna conceitual no ensino da língua. Embora ela reconheça as mudanças ocorridas na prática pedagógica em termos metodológicos, a autora afirma que o conteúdo do ensino pouco havia mudado, pautando-se ainda em modelos nativos da língua.

Apesar da existência de trabalhos descritivos de ILF, como o de Jenkins (2000) na descrição fonológica do inglês usado internacionalmente, além do estudo da pragmática na comunicação entre não-nativos, Seidlhofer (2001) critica a escassez desse tipo de projetos e declara a sua intenção de construir um corpus linguístico, o Vienna-Oxford International Corpus of English (VOICE) ${ }^{26}$, voltando sua atenção para o léxico e para a gramática e complementando o trabalho já feito em fonologia e pragmática.

O projeto tinha a intenção de coletar as variações da oralidade em ILF, entre falantes fluentes com diferentes repertórios linguísticos. Além disso, um trabalho empírico nesse sentido tinha como objetivo responder à seguinte questão: "isso já foi dito e compreendido em inglês como língua franca?"27 (SEIDLHOFER, 2001, p. 150), sugerindo que a validade de uma forma linguística se baseia na sua ocorrência prévia e na sua inteligibilidade.

Para os propósitos de coleta do corpus, a autora define ILF em seu sentido mais restrito:

[...] um sistema linguístico adicionalmente adquirido que serve como meio de comunicação entre falantes de diferentes primeiras línguas, ou uma língua por meio da qual os membros de diferentes comunidades de fala podem se comunicar uns com os outros mas que não é a língua nativa de nenhum deles - uma língua que não possui falantes nativos ${ }^{28}$ (SEIDLHOFER, 2001, p. 146).

Tal definição de ILF como um sistema linguístico não parece compreender a fluidez e a variabilidade desse uso da língua, indicando que se trataria de um sistema fechado adquirido

\footnotetext{
25 [...] with a great deal of variation but enough stability to be viable for lingua franca communication.

${ }^{26}$ Disponível em: 〈https://www.univie.ac.at/voice/>. Acesso em: 26 de março de 2019.

${ }^{27}[$ [...] has this been said and understood in English as a lingua franca?

${ }^{28}$ [...] an additionally acquired language system that serves as a means of communication between speakers of different first languages, or a language by means of which the members of different speech communities can communicate with each other but which is not the native language of either - a language which has no native speakers.
} 
para fins comunicacionais, ecoando uma visão de língua predominante na Modernidade, conforme mencionamos no Capítulo 1, como instrumento de comunicação, em que se pretendia chegar a uma padronização e homogeneização.

A menção a falantes nativos pode ser entendida de formas diferentes. De fato, para o objetivo da coleta de dados, falantes de inglês como primeira língua seriam excluídos das interações, que também não deveriam ocorrer em países do círculo interno, evitando, segundo a autora, a influência das normas do inglês nativo na comunicação em ILF. Nessa perspectiva, já é possível notar indícios de uma concepção de conhecimento que se pretende objetivo e neutro, uma vez que o objeto de análise deve estar isento de determinadas influências externas para que a coleta de dados seja a mais objetiva possível. Outra forma de entender essa definição é considerar que ILF seria uma forma do inglês tão diferente da usada por nativos que não pode ser considerada a primeira língua de ninguém.

Embora em 2005 as duas autoras tenham publicado trabalhos na área, é possível notar entendimentos diferentes acerca de ILF. Em seu artigo, Jenkins (2005) relata suas percepções decorrentes de entrevistas com professores de inglês a respeito da possibilidade de adotarem uma abordagem baseada no ILF e no Lingua Franca Core para o ensino de pronúncia. Nota-se que ainda não há uma distinção clara entre ILF e ILI, uma vez que Jenkins (2005) justifica o uso deste primeiro termo nas entrevistas pois a maioria dos participantes não estava familiarizada com o segundo.

Embora o artigo não se preocupe em definir ILF, é possível depreender um entendimento do conceito como o uso da língua inglesa entre falantes não-nativos, pautado principalmente no aspecto da pronúncia e dos sotaques nesses usos da língua, uma vez que as entrevistas buscam investigar a identificação dos professores com variantes não-nativas e sua disposição em ensinar o que Jenkins (2005, p. 536) chama de "ELF accents".

Já em Seidlhofer (2005, p. 339), ILF é localizado dentro do fenômeno de ILI e World Englishes e definido como:

[...] uma forma de se referir à comunicação em inglês entre falantes de diferentes primeiras línguas. [...] Embora isso não impeça a participação de falantes nativos de inglês na interação em ILF, o que distingue ILF é que, na maioria dos casos, ele é “uma 'língua de contato' entre pessoas que não compartilham uma língua nativa comum nem uma cultura nacional comum, e para quem o inglês é a língua estrangeira de comunicação escolhida" (Firth, 1996, p. 240) ${ }^{29}$.

29 [...] a way of referring to communication in English between speakers with different first languages. [...] Although this does not preclude the participation of English native speakers in ELF interaction, what is distinctive about ELF is that, in most cases, it is 'a 'contact language' between persons who share neither a common native tongue nor a common (national) culture, and for whom English is the chosen foreign language of communication' (Firth 1996: 240). 
Em relação à definição anterior (SEIDLHOFER, 2001) e ao entendimento de Jenkins (2005), nota-se aqui uma preocupação em não excluir falantes nativos das interações em ILF. Entretanto, o inglês é visto como a língua estrangeira de comunicação, o que volta a excluir aqueles que a falam como primeira língua, resultando em uma definição pouco clara do termo.

A descrição linguística e a construção de corpora são ainda vistas como essenciais para o estudo de ILF, como mostra o seguinte excerto (SEIDLHOFER, 2005, p. 340):

O trabalho empírico de descrição linguística de ILF em inúmeros níveis tem ocorrido
na verdade por vários anos. A pesquisa tem sido conduzida no nível fonológico
(Jenkins 2000), pragmático (Meierkord 1996), e lexicogramático (Seidlhofer 2004,
que também oferece um panorama do trabalho descritivo realizado). Os corpora de
ILF estão agora sendo compilados e analisados, tal como o English as a lingua franca
in Academic Setting (ELFA) (Mauranen 2003) e ao Vienna-Oxford International
Corpus of English (VOICE) (Seidlhofer 2004) ${ }^{30}$.

O objetivo do campo nesse momento era distinguir as características linguísticas formais que são cruciais para a inteligibilidade daquelas que, se usadas ou não, não causam problemas na interação, o que serviria de base para as escolhas pedagógicas no ensino de inglês para comunicação internacional.

À luz dos estudos em ILF, Jenkins (2006) comenta determinadas categorias das pesquisas de ASL que não mais se aplicariam às novas realidades nos usos do inglês e ao status global que o idioma adquiriu. Noções como a ideologia do falante nativo, interlíngua e fossilização são criticadas pela autora pois fariam parte do paradigma de ILE, que compreende o inglês como uma Língua Estrangeira Moderna, e não como uma língua franca. Jenkins (2006, p. 140, ênfases no original) então distingue o inglês dentro desses dois paradigmas e define ILF:

Pois o 'inglês' em 'Inglês como Língua Franca' é substancialmente diferente daquele em 'Inglês como uma Língua Estrangeira'. Acima de tudo, não é uma língua estrangeira aprendida para comunicação com seus falantes nativos. Em vez disso, é uma língua mundial cujos falantes se comunicam principalmente com outros falantes não-nativos, frequentemente de L1 diferentes das suas. Pertence, então, não à categoria das Línguas Estrangeiras Moderna, mas à categoria de World Englishes. ${ }^{31}$

Vemos, portanto, um distanciamento do ILE e uma aproximação dos estudos sobre WE, assim como em Seidlhofer (2005).

\footnotetext{
${ }^{30}$ Empirical work on the linguistic description of ELF at a number of levels has in fact been under way for several years now. Research has been carried out at the level of phonology (Jenkins 2000), pragmatics (Meierkord 1996), and lexicogrammar (Seidlhofer 2004, which also offers an overview of descriptive work to date). ELF corpora are now also being compiled and analysed, such as the English as a lingua franca in Academic settings (ELFA) corpus (Mauranen 2003) and the general Vienna-Oxford International Corpus of English (VOICE) (Seidlhofer 2004).

${ }^{31}$ For the 'English' in 'English as a Lingua Franca' is substantially different from that in 'English as a Foreign Language'. Above all, it is not a foreign language learnt for communication with its NSs. Rather, it is a world language whose speakers communicate mainly with other NNSs, often from different L1s than their own. It belongs, then, not to the category of Modern Foreign Languages, but to that of World Englishes.
} 
Enquanto língua estrangeira, a autora concorda que é aceitável que se almeje um nível de proficiência equiparado aos de um falante nativo, uma vez que aqueles que se dedicam a aprender uma segunda língua têm como objetivo comunicar-se com os nativos daquela língua. Mas no caso do inglês e sua função enquanto língua franca, tal objetivo torna-se dispensável.

Interessa-nos aqui fazer uma reflexão acerca da ideologia do falante nativo mencionada pela autora, que induz a reprodução das normas do círculo interno por aprendizes e falantes do círculo em expansão. Embora a crítica de Jenkins (2006) seja legítima no que se refere à necessidade de um rompimento com essas normas, a autora não problematiza a ideia de falante nativo em si, como se todos eles se inserissem em uma homogeneidade linguística, desconsiderando a heterogeneidade constitutiva da língua. Recuperamos aqui a crítica de Firth e Wagner (1997), mencionada no capítulo anterior, segundo a qual o uso dessas nomenclaturas acarreta uma homogeneização e trata cada um desses elementos enquanto entidades estáticas.

As noções de interlíngua e fossilização, caras aos estudos de ASL, são também problematizadas por ela. O conceito de interlíngua é definido por Larsen-Freeman e Long (1991 apud FIRTH; WAGNER, 1997) como um continuum pelo qual os estudantes passam entre a L1 e a L2 e o de fossilização é entendido como uma pausa na aprendizagem do sistema que leva à petrificação linguística. Essas noções são também criticadas por esses autores e por Canagarajah e Wurr (2011), pois uma vez que na comunicação multilíngue as normas são construídas na interação e não se pretende chegar a um nível específico de língua, a ideia de interlíngua perde seu sentido. Segundo os autores:

[...] temos que questionar os pressupostos no conceito de interlíngua de que há gradações, progressão linear, e um ponto final a ser alcançado na aprendizagem da língua. Vimos que cada interação multilíngue é uma realização social única, com seu próprio conjunto de participantes e línguas, trazendo desafios únicos para a negociação. Pode não ser o caso que um ato comunicativo contribui para outro e assim por diante, levando a uma linha cumulativa de progressão. Uma vez que os contextos são tão variáveis e imprevisíveis, não é possível dizer que um alvo pode ser alcançado para a proficiência multilíngue perfeita ou competente. No mais, podemos falar sobre atingir um tipo de consciência e competência linguística que pode ajudar a lidar com diversas situações comunicativas ${ }^{32}$ (CANAGARAJAH, WURR, 2011, p. 8-9).

Da mesma forma, a ideia de fossilização é problematizada por Firth e Wagner (1997), uma vez que os desvios em relação à fala nativa podem ser considerados como recursos e usados

\footnotetext{
32 [...] we have to question the assumption in the interlanguage concept that there are gradations, linear progression, and an endpoint to be achieved in language learning. We have seen that each multilingual interaction is a unique social accomplishment, with its own set of participants and languages, raising unique challenges for negotiation. It may not be the case that one communicative act contributes to the other and so on, leading to a cumulative line of progression. Since the contexts are so variable and unpredictable, it is not possible to say that a target can be reached for perfect or competent multilingual proficiency. If at all, we can speak of achieving a type of language awareness and competence that can help handle diverse communicative situations.
} 
de forma estratégica para atingir objetivos que a própria interação demanda, como promover empatia ou a mútua compreensão.

Compreendendo a necessidade de revisão dessas noções, consideramos válida a crítica de Jenkins (2006), mas fazemos aqui uma ponderação. Ao mesmo tempo em que ela reforça o afastamento dos estudos em ILF de determinadas categorias, tais como as noções acima mencionadas, ela se alinha a outras que, mesmo inseridas no paradigma do ILF, baseiam-se na mesma epistemologia positivista, compreendendo a língua em sua abstração. É o caso da necessidade da regularidade e sistematicidade das formas emergentes, através da comprovação empírica, como forma de legitimação desses usos, das noções de proficiência e das variantes em ILF.

Ao rebater a crítica feita aos estudos em ILF de que "anything goes" (JENKINS, 2006, p. 141), ou "qualquer coisa vale", uma vez que não se compreende a diferença da norma nativa como erro, mas sim como variação, a autora reforça que as formas linguísticas emergentes em ILF consideradas como variantes são "baseadas em sólida evidência empírica. Especificamente, as formas ocorrem sistemática e frequentemente, sem causar problemas na comunicação, usadas por falantes do círculo em expansão com alto nível de proficiência"33 (JENKINS, 2006, p. 141).

Tal afirmação demonstra que a validade e a legitimidade de ILF dependem da regularidade com que determinadas formas ocorrem. A noção de conhecimento aqui implicada baseia-se nas ideias de evidência, sistematicidade e objetividade, reforçando o que identificamos anteriormente como um indício. Com base em Canagarajah e Wurr (2011) em excerto acima citado, vimos que cada interação é única, os contextos são variáveis e imprevisíveis e, com isso, as formas que emergem fazem sentido naquele contexto. Portanto, a dependência da frequência e da regularidade como forma de legitimar esses usos da língua são problemáticas.

Jenkins (2006, p. 141) ainda menciona a questão da alta proficiência linguística dos usuários da língua, lembrando que:

[...] pesquisadores de ILF nunca afirmaram que não há algo como um falante nãoproficiente de ILF. Falantes de ILF, assim como falantes de ILE (e, nesse sentido, inglês nativo), possuem diferentes níveis de proficiência. [...] Em outras palavras, ILF possui sua própria escala de proficiência, embora o progresso ao longo dessa escala

\footnotetext{
${ }^{33}[\ldots]$ based on solid empirical evidence. In particular, the forms occur systematically and frequently, and without causing communication problems, in the speech of expanding circle speakers who have a high level of proficiency [...].
} 
em relação a variantes específicas de ILF (inglês alemão, inglês coreano e assim por diante) é ainda uma questão empírica. ${ }^{34}$

A noção de proficiência linguística é problemática porque implica uma totalidade no domínio da língua, não considerando os contextos nos quais o falante é capaz de se comunicar. Conforme Canagarajah (2017, p. 5), "é possível não ter proficiência na totalidade da língua (incluindo o que podemos considerar uma proficiência avançada ou mesmo básica nas estruturas gramaticais 'subjacentes') e ainda ser capaz de performar atividades significativas usando aquela língua" ${ }^{35}$, o que é exemplificado pelo autor com o caso de um acadêmico em astronomia que usava o inglês na função de língua franca e que, embora demonstrasse dificuldades em conversas informais, conseguia escrever artigos e debater as teorias no campo. Ou seja, seu desempenho na língua era contextual, e seu exemplo rompe com a ideia de uma gradação no conhecimento da língua do básico para o avançado, uma vez que uma conversa informal seria considerada uma atividade com baixo nível de dificuldade. Nesse mesmo sentido, Canagarajah e Wurr (2011) compreendem a noção de proficiência enquanto o alinhamento de repertório a demandas situacionais. Em comunidades multilíngues, falantes empregam diversas línguas de forma funcional, mesmo sem uma competência avançada na língua. Performatividade é uma noção que faz mais sentido para esse contexto, no qual é possível se expressar utilizando aspectos de uma língua mesmo sem deter uma competência avançada nela.

No excerto acima destacado (JENKINS, 2006, p. 141), a proficiência é ainda relacionada às variantes de ILF, como o inglês falado por alemães, por coreanos, dentre outros, o que indica a intenção de identificar variantes no inglês de acordo com as diferentes primeiras línguas de seus falantes. A ideia de fronteiras delimitadas entre variantes demonstra uma influência dos estudos de WE, que buscavam essa divisão linguística nas fronteiras de cada estado-nação, o que não abarca a complexidade no uso da língua no momento da interação.

Em Jenkins (2009, p. 200), ILF é definido como "um contexto específico de comunicação: o inglês sendo usado como língua franca, a língua comum de escolha, entre falantes de diferentes repertórios linguísticos e culturais" ${ }^{\text {"3 }}$. A autora esclarece que esse contexto de uso da língua inclui, principalmente, falantes não-nativos, uma vez que o maior

\footnotetext{
34 [...] ELF researchers have never claimed that there is no such thing as a non-proficient ELF speaker. ELF speakers, just like EFL (and, for that matter, native English) speakers, come in a range of proficiency levels. [...] In other words, ELF has its own proficiency clines, although progress along these clines in relation to specific ELF varieties (German English, Korean English and so on) is still largely an empirical question.

35 [...] one might not have proficiency in the whole of a language (including what we might consider an advanced or even a basic proficiency in the 'underlying' grammatical structure) and still be able to perform meaningful activities using that language.

36 [...] a specific communication context: English being used as a lingua franca, the common language of choice, among speakers who come from different linguacultural backgrounds.
} 
número de falantes de inglês é de usuários que não possuem o idioma como primeira língua. Isso não significa, segundo ela, que nativos sejam excluídos da definição de ILF, apenas que sua presença na interação não implica que as normas linguísticas sejam determinadas por eles. Desse modo, todos os que participam da interação devem negociar e ajustar sua fala para promover a inteligibilidade.

O foco na forma permanece como preocupação central dos estudos, especificamente como a primeira língua dos falantes influencia os aspectos formais do inglês, como exemplificado no seguinte excerto: "O terreno comum de ILF inevitavelmente contém formas linguísticas que compartilha com inglês como língua nativa, mas também contém formas que divergem do inglês como língua nativa emergentes do contato entre falantes de ILF, pela influência das primeiras línguas dos falantes de ILF em seu inglês"37 (JENKINS, 2009, p. 201). Essa ênfase também é percebida quando Jenkins (2009, p. 201) menciona o critério de restringir a quantidade de falantes nativos na coleta de dados, "para garantir que eles não distorçam os dados com um excedente de formas do inglês como língua nativa" ${ }^{38}$. Além disso, a autora adiciona aqui o interesse pelos processos que levam à criação dessas formas, como a regularização.

Como em Jenkins (2006), nota-se ainda a esperança de identificar as diferentes variantes do inglês falado em contexto internacional, do mesmo modo, segundo a autora, que é possível diferenciar entre o inglês norte-americano, britânico, australiano, dentre outras. Prevalece aqui a mesma crítica a respeito de uma percepção homogênea e delimitada dessas variantes. Além disso, as noções de proficiência, sistematicidade e, ainda, a frequência com que determinadas formas ocorrem, continuam a ser determinantes na distinção entre variação e erro. A autora conclui com uma aproximação entre o paradigma do WE e do ILF, afirmando que entre eles há mais similaridades do que diferenças.

Cabe aqui refletirmos acerca dessas primeiras definições de ILF e dos métodos de pesquisa empregados nessa fase inicial de estudos, buscando esclarecer, como já fizemos em algumas passagens, a concepção de conhecimento que os embasam e identificar historicamente as suas bases.

Percebemos que o estudo do conceito de ILF desenvolvido até aqui, com sua ênfase no aspecto formal, demonstra uma concepção estruturalista de língua, que, segundo Canagarajah

\footnotetext{
${ }^{37} E L F$ 's common ground inevitably contains linguistic forms that it shares with ENL, but it is also contains forms that differ from ENL and that have arisen through contact between ELF speakers, and through the influence of ELF speakers' first languages on their English.

${ }^{38}$ [...] to ensure that they do not distort the data with a surplus of ENL forms.
} 
(2017), a considera como uma entidade abstrata, uma estrutura fechada, separada de outras modalidades de comunicação e independente do contexto espaço-temporal (história, geografia, política, cultura e sociedade), impondo ordem, controle e normatividade sobre a complexidade e a materialidade da vida social. Além disso, os procedimentos de descrição e codificação das formas linguísticas pretendidos por Jenkins (2000, 2005, 2006a, 2006b, 2015, 2017) e Seidlhofer (1999, 2001, 2005, 2009) ecoam práticas diante da língua semelhantes àquelas conduzidas na colonização e na construção dos estados-nação, que tinham como objetivo suprimir as variações e normatizar o uso da língua.

A descrição linguística, conforme nos lembra Pennycook (2004), serviu como forma de utilizar as diferenças como um recurso que naturalizasse a desigualdade no território colonial. Segundo o autor, no projeto colonizador, mediam-se e descreviam-se pessoas, lugares, territórios, línguas e culturas. As línguas dos colonizados eram padronizadas, criando uma ideologia de língua como entidades separadas, objetos autônomos no mundo, passíveis de classificação.

Essas mesmas práticas coloniais são mencionadas por Heller e McElhinny (2017), ao comentarem sobre a dominação espanhola na península Ibérica e a tentativa de codificar as línguas centrais da região. Tal procedimento objetivava estabilizar a língua, isso porque a heterogeneidade era associada à barbárie e a sociedades rudimentares. Para serem legitimadas, línguas deveriam ser examinadas e classificadas; para isso, sua estabilidade, mesmo que criada, era necessária. Hierarquias entre as línguas e as culturas dos povos dominados e dominadores foram estabelecidas como forma de naturalizar a opressão e as desigualdades produzidas.

Mais tarde, as teorias darwinistas de evolução biológica foram trazidas para a antropologia, pautadas na premissa de que as línguas eram objetos do mundo natural e, portanto, estavam sujeitas às mesmas leis e também aos mesmos procedimentos de análise, enfatizando a noção de um conhecimento pronto e objetivo, que restava apenas ser descoberto. A ciência do século XIX esforçava-se em observar e descrever o mundo natural, identificando suas regularidades, e a linguística, por sua vez, seguia o mesmo caminho, voltando sua atenção para a oralidade, considerada a dimensão mais natural da língua e a mais passível de ser observada cientificamente (HELLER; McELHINNY, 2017).

O objetivo da linguística nesse período era, portanto, descrever a língua falada, demonstrando, mais uma vez, uma tentativa de estabilizar a língua. O uso dos mesmos procedimentos de análise e de estudo utilizados pelas ciências naturais eram uma forma de dar legitimidade e cientificidade ao estudo das línguas. 
Reforçando essa visão estruturalista de língua, os estudiosos em ILF pretendiam ainda, como vimos, codificar as variantes do inglês com base na primeira língua dos usuários, atribuindo cada variante a um grupo determinado de falantes, a uma comunidade de fala ou mesmo a um determinado território, como, por exemplo, descrever uma variante brasileira de inglês. Esses são conceitos que, segundo Canagarajah (2017), relacionam a língua a um determinado território e a um determinado grupo de falantes.

Pennycook (2004) recupera os ecos colonialistas dessas noções, como a vinculação entre língua e território, além das pretensas fronteiras entre as línguas. De acordo com o autor:

As autoridades coloniais e os missionários 'compartilhavam uma lógica territorial que
era similarmente inscrita no trabalho linguístico colonial, pressupondo o mapeamento
de língua monolíticas em fronteiras demarcadas... No interior desses confins
limitados concebiam-se grupos homogêneos etnolinguisticamente que eram
localizados e naturalizados como 'tribos' ou 'etnias' (Errington, p. 24). Filologia
comparada, como as muitas seções do arquivo de conhecimento colonial europeu,
emergiu simultaneamente com a expansão colonial na Ásia, África e Oriente Médio
no século XIX. Conforme ela se desenvolveu para a linguística moderna, com suas
hierarquias, línguas fixas, árvores linguísticas, e assim por diante, levou consigo muito
dos pressupostos coloniais que trouxe a sua emergência ${ }^{39}$ (PENNYCOOK, 2004, p.
3-4).

Reforçando essa mesma relação entre língua e espaço, Heller e McElhinny (2017) mencionam a dialetologia, abordagem de análise da fala desenvolvida durante o século XIX preocupada com a variabilidade e com a mudança linguística, na qual se buscava os limites territoriais de determinadas formas linguísticas, fossem elas palavras ou sons (HELLER; McELHINNY, 2017).

Também considerando a mudança linguística e em consonância com as análises desenvolvidas nas ciências naturais, os Neogrammarians da Alemanha conduziam sua pesquisa científica utilizando o som como elemento ideal para a análise. Segundo Heller e McElhinny (2017), esses estudiosos, assim como os cientistas de outras áreas de sua época, buscavam as leis da natureza e o som era visto como um elemento do mundo natural por estar diretamente ligado ao sistema articulatório. Além disso, era possível observá-lo e medi-lo empiricamente. Segundo eles, as alterações sonoras levavam à mudança linguística.

\footnotetext{
${ }^{39}$ Colonial authorities and missionaries shared a territorial logic that was similarly inscribed in colonial linguistic work, presupposing mappings of monolithic languages onto demarcated boundaries... Within these bounded confines were conceived to be ethnolinguistically homogeneous groups that were localized, and naturalizes, as 'tribes' or 'ethnicities'" (Errington, p. 24). Comparative philology, like many sections of the European colonial knowledge archive, emerged simultaneously with colonial expansion in Asia, Africa and the Middle East in the $19^{\text {th }}$ century. As it then developed into modern linguistics, with its hierarchies, fixed languages, language trees, and so forth, it carried with it many of the assumptions of the colonial collateral that brought about its emergence.
} 
Embora não possamos afirmar que esses estudiosos tiveram alguma influência nas pesquisas sobre ILF, é curioso observar que Jenkins, em sua fase inicial de pesquisa, se dedicou justamente à análise fonológica desse uso da língua, buscando também identificar suas regularidades.

Os anos 1960 assistiram à emergência da sociolinguística, campo que tinha como objetivo, através da união entre a linguística, a sociologia, a psicologia e a antropologia, combater as desigualdades e refazer o mundo pós-guerra, ainda baseados na noção moderna de progresso. Para isso, pretendiam "trazer progresso para os marginalizados e valorizar formas estigmatizadas, abrindo as portas para aqueles anteriormente não representados em círculos linguísticos institucionalizados"40 (HELLER; McELHINNY, 2017, p. 204). A intenção, portanto, era legitimar os usos até então considerados deficientes da língua de comunidades de fala relativamente unificadas. $\mathrm{O}$ fato de considerarem as línguas como autônomas e privilegiarem a análise estrutural e sistemática de dados empíricos, conforme afirmam os mesmos autores, fez com que os pressupostos do campo fossem os mesmos empregados até então.

A intenção dos estudiosos de ILF em muito se assemelha ao que a sociolinguística pretendia fazer em seu início, uma vez que o objetivo do campo era legitimar esses usos marginalizados do inglês, há muito considerados como desvios de acordo com as normas linguísticas de países hegemônicos. Da mesma forma que a sociolinguística prezava a análise sistemática de dados empíricos, também os estudos sobre ILF valorizavam essa forma de estudar a língua, resultando na compilação de corpora linguísticos, descrição e análise dos dados coletados.

Tais procedimentos de pesquisa e análise linguística predominaram na constituição do estado moderno. Enquanto em algumas dessas visões o objetivo era estabelecer uma norma estável de língua, tentando suprimir a heterogeneidade da língua e estigmatizar suas variações, em outras a intenção era justamente valorizar e legitimar a diferença linguística. Entretanto, notamos que o modo de investigação e análise pouco mudava, revelando posturas semelhantes diante da forma de chegar ao conhecimento, ou seja, demonstram partir de uma mesma epistemologia.

A busca por regularidades, como mencionado acima, também demonstra uma postura em relação ao conhecimento parecida com aquelas desenvolvidas no século XIX influenciadas

\footnotetext{
40 [...] to bring progress to the marginalized and to value stigmatized forms of difference, opening the door to those previously not represented in institutionalized linguistic circles.
} 
pelos mesmos métodos de pesquisa das ciências naturais, em que se pretendia identificar as leis naturais das línguas, como forma de garantir sua legitimidade e cientificidade.

Não pretendemos, com isso, sugerir que os estudiosos de ILF tomaram os exemplos aqui mencionados como referência, mas sim que suas concepções se inserem em uma herança epistemológica colonial e moderna. Embora tenham tido a intenção inicial de estudar as variações do inglês em contexto internacional e legitimar os usos não hegemônicos do idioma, suas concepções ecoavam posturas e práticas que, historicamente, tiveram como objetivo suprimir a diferença e justificar a opressão e a desigualdade com base na língua, o que nos faz questionar a pertinência de tal epistemologia ao objetivo pretendido.

Dessa forma, vemos o quanto esse projeto incipiente nos estudos de ILF se aproxima com uma concepção estruturalista característica da linguística moderna, através da tentativa de encontrar ordem em meio à complexidade linguística, e revela uma concepção de conhecimento pautado nos mesmos pressupostos que embasaram a ciência moderna, que, por sua vez, pressupõe uma realidade objetiva e pronta, cujo objetivo do pesquisador é descobrir suas leis, buscando critérios de validade ou falsidade que definam o que é ou não considerado como conhecimento, traçando a linha abissal mencionada por Sousa Santos (2007).

Prosseguindo com nossa análise sobre o conceito, partimos para Seidlhofer (2009), que, assim como Jenkins (2006), encara os paradigmas de ILF e WE como compatíveis e enfatiza suas semelhanças a despeito das diferenças.

ILF novamente é entendido na sua relação com falantes nativos, em que "interações nas quais mais do que frequentemente falantes nativos não participam - a saber, inglês como língua franca $^{41 "}$ " (SEIDLHOFER, 2009, p. 237). O sentido do termo língua franca, especificamente, é também explicado:

[...] o termo 'língua franca', como entendido no acrônimo ILF, não denota um código 'empobrecido', conveniente e improvisado por falta de algo melhor, mas um recurso compartilhado vibrante, poderoso e versátil que permite a comunicação através de fronteiras linguísticas e geográficas ${ }^{42}$ (SEIDLHOFER, 2009, p. 242).

A autora volta a criticar a falta de corpora linguísticos com interações em inglês em contexto de língua franca que viabilizem a descrição linguística desse uso da língua. Para ela, a fluidez inerente de ILF não impede sua codificação, vista como essencial para a legitimidade e reconhecimento do conceito. O que muda, segundo Seidlhofer (2009), é o foco dessa

\footnotetext{
41 [...] interactions in which more often than not no native speakers participate - namely English as a lingua franca.

42 [...] the term 'lingua franca' as understood in the acronym ELF does not denote an 'impoverished', purely expedient and makeshift code for lack of something better, but a vibrant, powerful, and versatile shared resource that enables communication across linguistic and geographic boundaries.
} 
descrição, de características formais para o significado subjacente a essas formas e às funções que desempenham, uma vez que, no uso de ILF, o sentido das formas usadas é explorado como um recurso comunicativo.

Nessa perspectiva, declara-se a intenção de valorizar a negociação de significados na interação, com menor ênfase no código linguístico. Fronteiras entre as línguas também começam a ser vistas como tênues, questionando denominações tais como World Englishes, uma vez que implicam uma separação entre entidades linguísticas. Nesse sentido, cabe aqui questionar a aproximação que a autora propõe entre os paradigmas de ILF e WE, uma vez que os estudos deste último entendem que é possível estabelecer uma delimitação clara entre as diversas variantes nativizadas de inglês e identificá-las dentro das fronteiras nacionais.

Jenkins, Cogo e Dewey (2011) apresentam duas definições de ILF, nas quais a diferença reside na inclusão ou não de falantes nativos no conceito. A primeira é a definição apresentada no website VOICE, no qual ILF é entendido como "um sistema linguístico adquirido adicionalmente que serve como meio de comunicação para falantes de diferentes primeiras línguas"43 (JENKINS; COGO; DEWEY, 2011, p. 283), o que, segundo os autores, não exclui falantes nativos, pois ILF seria diferente do Inglês como Língua Nativa, e aqueles que possuem inglês como sua primeira língua e desejam comunicar-se internacionalmente devem também adquirir essa língua adicional. Já a segunda definição exclui nativos pois entende ILF como “uma 'língua de contato' entre pessoas que não compartilham uma língua nativa comum nem uma cultura (nacional) comum e para quem o inglês é a língua estrangeira de comunicação escolhida) ${ }^{44 "}$ (FIRTH, 1996, p. 240 apud JENKINS; COGO; DEWEY, 2011, p. 283). Tal definição considera o inglês como uma língua estrangeira de comunicação, sendo assim, falantes nativos não seriam considerados falantes estrangeiros de inglês e, portanto, são excluídos do conceito de ILF, embora a minoria dos pesquisadores adote tal visão.

Enquanto em Jenkins (2006) ILF é inserido dentro do paradigma do WE e em Jenkins (2009) a autora ressalta a aproximação entre os dois campos de estudo, em Jenkins, Cogo e Dewey (2011) um distanciamento entre eles é estabelecido, admitindo que uma abordagem ligada à delimitação de variantes não se aplicaria à fluidez do inglês em contexto de língua franca. De acordo com os autores, enquanto a pesquisa em World Englishes foca no estudo de variantes delimitadas do inglês, essa orientação através de variantes não é mais viável para a

\footnotetext{
43 [...] an additionally acquired language system which serves as a common means of communication for speakers of different first languages.

44 [...] a 'contact language' between persons who share neither a common native tongue nor a common (national) culture and for whom English is the chosen foreign language of communication' (1996: 240; emphasis in original).
} 
pesquisa em ILF uma vez que o inglês se relaciona com os processos de globalização, devendo, portanto, "focar no inglês como fluido, flexível, contingente, híbrido e profundamente intercultural"45 (JENKINS; COGO; DEWEY, 2011, p. 284).

Paralelamente à identificação das regularidades formais, já presente nos objetivos das pesquisas em ILF, propõe-se também que o foco recaia na variabilidade da língua, sendo esta a característica que define ILF, o que indica uma ressignificação do conceito e uma redefinição de objetivos de pesquisa. Alinhados a Seidlhofer (2009), eles afirmam que não mais as características formais serão foco principal dos estudos em ILF, mas sim o uso funcional dessas formas e do que elas representam. Pretende-se, nessa fase, investigar os processos que geram as formas, mas sem ignorar as regularidades.

Em resenha sobre Understanding English as a Lingua Franca, obra de Seidlhofer de 2011, Alptekin (2012) chama a atenção para a inclusão de falantes nativos na definição oferecida pela autora. Segundo Alptekin (2012, p. 248):

[...] ela afirma que ILF se refere a 'qualquer uso do inglês entre falantes de diferentes primeiras línguas para quem o inglês é o meio de comunicação escolhido e frequentemente a única opção' (p. 7). Esse conceito é fundamentalmente diferente daqueles oferecidos por Firth (1996) e House (1999), que excluíram das interações em ILF falantes de inglês como língua nativa (ILN), e daquele de Jenkins (2007, p. 4), que vê o ILF principalmente como uma língua de comunicação entre falantes nãonativos de inglês, não entre falantes nativos e não-nativos de inglês. ${ }^{46}$

Paradowski (2013, p. 312), também em resenha sobre a obra, destaca esse mesmo aspecto e resume a definição como:

[...] qualquer uso do inglês entre falantes de diferentes línguas maternas e repertórios linguístico culturais, através dos três círculos de Kachru. Em contraste a algumas definições conceituações anteriores (e. g. House 1999, Jenkins 2007), essa inclui falantes nativos de inglês, que por motivos de comunicação intercultural podem usar ILF como sua língua adicional. ${ }^{47}$

Essas mudanças levaram Canagarajah (2013) a afirmar que ILF se aproximou gradualmente de uma perspectiva baseada na prática, referindo-se à perspectiva da prática translíngue defendida por ele. Entretanto, mesmo com a mudança de enfoque, o autor ainda identifica certas inconsistências nesses estudos e promove algumas críticas ao campo. Segundo

\footnotetext{
${ }^{45}$ [...] focus on English as fluid, flexible, contingent, hybrid and deeply intercultural.

${ }^{46}$ [...] she states that ELF refers to 'any use of English among speakers of different first languages for whom English is the communicative medium of choice, and often the only option' (p. 7). This conceptualization is fundamentally different from those offered by Firth (1996) and House (1999), who excluded from ELF interactions English as a native language (ENL) speakers, or from that of Jenkins (2007: 4), who sees ELF as primarily a language of communication among the NNSs of English, not between NSs of English and NNSs.

${ }^{47}[. .$.$] any use of English among speakers of different mother tongues and linguacultural backgrounds, across all$ three Kachruvian circles. In contrast to some earlier definitions and conceptualizations (e.g. House 1999, Jenkins 2007), this importantly includes native speakers of English (NSs), who for aims of intercultural communication may use ELF as their additional language.
} 
ele, os estudos formais ainda ocupam um lugar de importância na pesquisa de ILF, a fim de provar sua sistematicidade e lógica e, com isso, sua legitimidade, enquanto as estratégias de negociação são vistas como suplementares. Tal entendimento difere de uma abordagem pautada na prática translíngue, que foca no sucesso comunicativo através de estratégias de negociação, e as formas são vistas como emergentes dessas estratégias.

Ele também problematiza o conceito de comunidade de prática adotado por Seidlhofer (2009), em oposição ao conceito de comunidade de fala que ela vê como inadequado para a análise de ILF: "um conceito muito mais apropriado é o de comunidades de prática, caracterizado pelo 'engajamento mútuo' em práticas compartilhadas, ocorrendo em algum 'empreendimento' conjuntamente negociado e fazendo uso dos 'repertórios compartilhados dos membros""48 (SEIDLHOFER, 2009, p. 238 apud CANAGARAJAH, 2013, p. 65). Sua crítica aponta para a concepção de repertório da autora, como algo já existente, e não emergente da prática, uma vez que, numa perspectiva translíngue, não são os repertórios pré-existentes e as formas compartilhadas que são considerados para garantir a inteligibilidade e o sucesso na comunicação, mas sim o uso de estratégias de negociação.

Para o autor, portanto, são elas que facilitam a interação e a produção de significados, atribuindo um papel secundário ao repertório compartilhado pré-existente à prática. Ademais, a necessidade de apoio em uma comunidade como forma de dar identidade à língua é uma categoria teórica que o ILF percebe como essencial, diferente da perspectiva translíngue, uma vez que Canagarajah (2013) afirma a possibilidade de alcançar a comunicação em zonas de contato sem uma comunidade.

Embora Seidlhofer (2009) afirme que tentou se aproximar de uma visão mais processual e comunicativa de ILF, em que as características não são analisadas com um fim nelas mesmas, mas sim na função que desempenham nas interações, ainda assim Canagarajah (2013) faz a ressalva de que tais características não são analisadas como emergentes das práticas, e sim na função que assumem.

Ele também menciona Jenkins (2000, 2006a, 2009) e Jenkins, Cogo e Dewey (2011) para ilustrar a ênfase que os estudiosos do campo parecem dar ao compartilhamento de normas, quando a autora diz que ILF envolve tanto uma base comum quanto variação local, sendo essa base comum definida em termos formais de falantes proficientes de inglês, o que demonstra, segundo o autor, uma necessidade por estabilidade e sistematicidade. Já na prática translíngue,

\footnotetext{
${ }^{48}$ A much more appropriate concept is that of communities of practice characterized by 'mutual engagement' in shared practices, taking part in some jointly negotiated 'enterprise', and making use of members' 'shared repertoire'.
} 
a inteligibilidade pode ser alcançada sem a necessidade de normas linguísticas comuns e sem uma competência linguística avançada nessas normas, apenas adotando estratégias comunicativas.

O autor reconhece um avanço no campo do ILF em direção a uma concepção mais orientada ao translinguismo quando os estudos passaram a considerar também interações com falantes nativos, antes apartados dessas análises, enfatizando que mesmo quando eles participam da interação em ILF, não são eles que definem as normas da comunicação.

Canagarajah (2013) considera que tais inconsistências são decorrentes da falta de esclarecimento filosófico da área, afirmando que o trabalho teórico não acompanhou a sofisticação do trabalho empírico. Segundo o autor, "apresentar as teorias sociais e os construtos filosóficos que o embasa asseguraria o progresso de ILF"49 (CANAGARAJAH, 2013, p. 67). Além disso, tratar de questões relacionadas a poder e identidade também ajudariam os estudos em ILF a avançar.

Uma crítica semelhante é feita por O’Regan (2014) a partir de uma perspectiva do marxismo, da teoria da globalização e do pós-estruturalismo. Ele alega que os trabalhos em ILF se apropriam de certas categorias pós-estruturalistas e pós-modernas, sem, no entanto, se engajar na discussão de conceitos imprescindíveis para qualquer estudo que se afirme como pós-estruturalista ou pós-moderno, que são ideologia, poder, discurso, verdade e realidade. Mesmo quando mencionados, são tratados, segundo o autor, de forma superficial. Essa apropriação acrítica e o modo como o campo do ILF se relaciona com o conhecimento levam O’Regan (2014) a afirmar a inserção dos estudos em ILF em uma epistemologia positivista, racionalista e objetivista.

Baker e Jenkins (2015) respondem a essa crítica afirmando que muitos desses conceitos são tematizados por estudiosos de ILF, envolvendo questões de ideologia da língua padrão e do falante nativo, assim como as relações de poder nelas envolvidas, mesmo que assumam uma abordagem distinta da que O'Regan (2014) defende. Os autores justificam a falta de teorização prévia sobre esses conceitos, problematizada por O’Regan (2014) e também por Canagarajah (2013), argumentando que "tal pesquisa não se beneficiaria de teorias a priori ou uma única explicação de ideologia, discurso, poder, verdade e realidade" 50 (BAKER; JENKINS, 2015, p.

\footnotetext{
49 Bringing out the social theories and philosophical constructs underlying the model would steady ELF's progress.

50 [...] such inquiry would not benefit from a priori assumptions or a single explanation of ideology, discourse, power, truth, and the real [...].
} 
196), uma vez que, desde seu início, o campo desenvolve e adapta suas teorias a partir dos problemas práticos que encontra, em vez de decidi-las previamente.

Alinhando-nos com Canagarajah (2013) e O'Regan (2014) e partindo de uma perspectiva decolonial, entendemos que o não esclarecimento de determinadas noções subjacentes aos seus estudos não significa que eles não sejam embasados em alguma epistemologia. Relacionamos as críticas desses autores com o que Sousa Santos (2007, p. 85) considera essencial para que se comece a pensar de forma pós-abissal:

[...] o reconhecimento da persistência do pensamento abissal é condição sine qua non para começar a pensar e a agir para além dele. Sem esse reconhecimento, o pensamento crítico permanecerá um pensamento derivativo, que continuará a reproduzir as linhas abissais por mais antiabissal que se autoproclame.

Com base nisso, nossa busca por rastros que evidenciem as bases epistemológicas e ontológicas nos trabalhos de ILF nos levam a perceber que as mudanças empreendidas nos trabalhos do campo a partir de 2009 não implicam, no geral, uma mudança nessas mesmas bases. Embora essa redefinição de objetivos pretenda focar na variabilidade da língua e as fronteiras entre as variantes comecem a ser vistas de forma mais fluida, a busca por regularidades e a intenção de descrever e codificar esse uso da língua para a construção de corpora linguísticos permanecem como forma de legitimar esse uso da língua. Ou seja, o entendimento do que é um conhecimento legítimo e da forma de se chegar a ele não se alteraram. Usando os termos de Sousa Santos (2007), trata-se de um pensamento derivativo que apenas reproduz as linhas abissais que afirmam combater. Além disso, a falta de esclarecimento a respeito de qual perspectiva os trabalhos de ILF partem soa como uma pretensa tentativa de neutralidade, objetividade e universalidade, ressoando aquilo que pensadores decoloniais denominam como ego-política do conhecimento, definida em entrevista com Grosfoguel como:

[...] a epistemologia que inaugura René Descartes como fundamento da filosofia moderna em meados do século XVII. A epistemologia cartesiana se caracteriza pelo lema "Eu penso, logo existo". Este "Eu" é abstrato, não se situa em nenhum lugar de acordo com a epistemologia cartesiana. É um ponto de vista que não se assume como ponto de vista. ${ }^{51}$ (MONTOYA; BUSSO, 2007, p. 4)

Segundo Grosfoguel (2007), as características de neutralidade e objetividade são heranças da epistemologia cartesiana, adotada pelas ciências humanas a partir do século XIX, cujo sujeito que produz conhecimento se coloca no ponto zero, não possui rosto, corpo e nem localização geográfica. É um ponto de vista que não se assume como ponto de vista pois se

\footnotetext{
51 [...] la epistemología que inaugura a mediados del siglo XVII René Descartes como fundamento de la filosofía moderna. La epistemología cartesiana se caracteriza por el lema de "Yo pienso luego existo". Este "Yo" es abstracto, no se sitúa en ningún lugar de acuerdo a la epistemología cartesiana. Es un punto de vista que no se asume a sí mismo como punto de vista.
} 
pretende universal. E o fato de a produção científica em ILF ter tido sua gênese na Europa corrobora aquilo que Mignolo (2007) nos lembra sobre a tendência que temos em considerar o conhecimento proveniente da Europa como se fosse deslocalizado.

Mais uma ressignificação nos objetivos de pesquisa em ILF é anunciada por Jenkins (2015) depois de a autora identificar as diferentes fases pelas quais esse campo de estudos percorreu desde o seu início.

De acordo com a pesquisadora, seu projeto na fase inicial tinha a intenção de identificar um Lingua Franca Core, ou núcleo de sons segmentais e prosódicos da fala nativa que costumava causar problemas de inteligibilidade em interações interculturais, além daqueles cuja presença ou ausência não afetava a mútua compreensão. Também foram consideradas as estratégias de acomodação dos falantes, nas quais eles ajustavam sua pronúncia para promover a inteligibilidade.

Ao comentar sobre a primeira fase de ILF, a autora afirma que embora o foco tenha sido nas formas, também se deu atenção às estratégias de acomodação na comunicação. Tal afirmação sugere que os processos de acomodação, portanto, não se relacionam com a forma. Mas se nos atentarmos ao que eles se referem, notamos que se tratam justamente de mudanças formais na fala, tal como um aspecto específico da pronúncia que dificulta a compreensão de uma palavra.

Já os estudos em léxico e gramática resultaram na construção de dois corpora, o ViennaOxford International Corpus of English (VOICE), de Seidlhofer, e o Corpus of English as a Lingua Franca in Academic Settings (ELFA), de Mauranen (JENKINS, 2015). Seidlhofer dedicou-se então à formulação de hipóteses lexicogramaticais, itens usados por falantes de diferentes repertórios linguísticos com regularidade sem causar problemas à comunicação.

Nesse primeiro momento, influenciados pelo paradigma do WE, os estudiosos em ILF ainda acreditavam que era possível descrever e codificar as variantes em ILF, de acordo com os traços comuns entre falantes de diferentes primeiras línguas, além daqueles específicos de cada língua, identificando o que seriam variantes de inglês japonês, alemão, dentre outras.

A percepção da fluidez e da variabilidade nos usos da língua inglesa influenciadas pelos diferentes repertórios linguísticos presentes nas situações comunicativas levaram os estudos de ILF a uma segunda fase. Segundo Jenkins (2015), Seidholfer (2009) notou que os falantes faziam uso de seu repertório multilíngue na interação para negociar sentidos e ela propôs então a investigação dos processos que motivavam os usos de formas variadas pelos falantes. A abordagem segundo Comunidades de fala, baseada em variantes, foi substituída pela de Comunidades de prática, a fim de se ajustar às realidades da comunicação internacional. Mesmo 
com essa mudança de enfoque, a discussão pautava-se ainda em uma perspectiva monolíngue, pois a atenção era voltada ao inglês e a como ele era influenciado pelas outras línguas na mente multilíngue.

Essa redefinição de objetivos marcou o distanciamento conceitual entre os paradigmas de WE e ILF, pois enquanto os estudos de WE se pautavam na delimitação de variantes nos limites do território, essa abordagem mostrou-se inalcançável para a pesquisa em ILF.

A emergência de estudos sobre translinguismo contribuiu para mais uma ressignificação dos propósitos da área e do conceito de ILF. Nessa perspectiva, as línguas não são vistas como sistemas fechados e autônomos. Em vez disso, considera a mútua relação entre elas, resultando em "um sistema trans-semiótico com muitos signos que produzem sentido, principalmente os linguísticos, que se combinam para compor o repertório semiótico de alguém"52 (GARCÍA; LI WEI, 2014, p. 42 apud JENKINS, 2015, p. 60-61). Para os estudos em ILF, isso aponta para uma ênfase na negociação de sentidos e na pragmática, em vez de priorizar as influências nas formas linguísticas do inglês. Uma redefinição do conceito é proposta por Jenkins (2015, p. 7374), chamada de Inglês como uma Multilíngua Franca:

Uma comunicação multilíngue na qual o inglês está disponível como uma língua de contato de escolha, mas não necessariamente escolhida. Em outras palavras, Inglês como uma Multilíngua Franca se refere aos cenários comunicativos multilíngues nos quais o inglês é conhecido para todos os presentes, e está sempre potencialmente 'na mistura', independentemente de ser ou não realmente usado e o quanto. ${ }^{53}$

Jenkins (2017) reforça tais mudanças nos estudos e no conceito de ILF. A atenção às formas, segundo a autora, deixou de ser o foco da área para dar lugar à flexibilidade e à variabilidade na interação, uma vez que as características linguísticas emergem da interação e são impossíveis de serem codificadas, como antes se pretendia.

A ênfase no inglês também é menor nesse momento, uma vez que as primeiras ou outras línguas que fazem parte do repertório daqueles que se comunicam em contexto de língua franca passam a ganhar mais importância com a influência dos estudos em multilinguismo e translinguismo.

Novamente a autora propõe o termo que ela considera melhor representar essa concepção, Inglês como Multilíngua Franca, já que outras línguas também podem se fazer

\footnotetext{
52 [...] a trans-semiotic system with many meaning-making signs, primarily linguistic ones, that combine to make up a person's semiotic repertoire.

${ }^{53}$ Multilingual communication in which English is available as a contact language of choice, but is not necessarily chosen. In other words, English as a Multilingua Franca refers to multilingual communicative settings in which English is known to everyone present, and is therefore always potentially 'in the mix', regardless of whether or not, and how much, it is actually used.
} 
presentes na interação, "[n]ão estamos falando sobre o inglês, mas sobre 'inglês em meio ao multilinguismo’ (Jenkins, no prelo)" "54 (JENKINS, 2017, p. 345).

Seidlhofer e Widdowson (2017) voltam a mencionar a negociação de sentidos na interação como característica da comunicação em ILF. Em resposta a um artigo de Modiano (2017), em que o autor reflete sobre as possíveis consequências do Brexit ${ }^{55}$ sobre o uso e na função do inglês na União Europeia, os autores esclarecem que ILF não se trata de uma variante com características formais específicas. Em suas palavras:

As interações em ILF não ocorrem em 'variedades de ILF' esperando para serem codificadas, mas através do emprego de recursos linguísticos apropriados às exigências de cada evento de fala. O que é fascinante sobre as tentativas para entender como essa negociação de sentidos funciona é como os falantes são flexíveis e criativos em se ajustar às necessidades comunicativas de contextos particulares. A pesquisa em ILF serve como um lembrete salutar do risco profissional que linguistas correm: de atribuir um significado desproporcional às formas linguísticas usadas na comunicação em vez do processo de negociação e adaptação no uso comunicativo real ${ }^{56}$ (SEIDLHOFER; WIDDOWSON, 2017, p. 361).

Quando contrastamos esse excerto com aquela primeira definição oferecida por Seidlhofer (2001, p. 146), percebemos aqui a ênfase na ideia de recursos linguísticos em detrimento da noção de língua como sistema lá apresentada. O privilégio antes dado à forma é agora criticado para se voltarem à negociação de sentidos na situação comunicativa. Além disso, a codificação de variantes, objetivo dos primeiros estudos da área, é então substituída pela valorização da criatividade e flexibilidade dos falantes em cada contexto comunicativo.

Essas últimas definições de ILF parecem se aproximar de uma visão mais fluida, dinâmica e aberta de língua, semelhante ao que Canagarajah (2013) entende como uma prática translíngue. Até mesmo a noção de comunidade de prática, antes proposta como adequada para pensar o uso de ILF e criticada por Canagarajah (2013), é revisitada pela autora, uma vez que as interações em ILF costumam ser transitórias, considerando agora a noção de zona de contato como mais adequada. Além disso, a necessidade de um repertório prévio compartilhado também é relativizada.

Com as contribuições do translinguismo, o campo parece apontar para uma revisão dessa concepção, atribuindo maior importância aos elementos emergentes da interação. Além

\footnotetext{
54 We are thus talking not about English, but 'English within multilingualism' (Jenkins, in press).

55 Processo de saída do Reino Unido da União Europeia.

56 ELF interactions are not carried out in various 'ELF varieties' waiting to be codified but through a variable expedient deployment of linguistic resources as appropriate to the requirements of any specific speech event. What is fascinating about attempts to understand how this negotiation of meaning works is just how flexible and creative speakers are in adjusting to the communicative needs in particular contexts. ELF research thus serves as a salutary reminder of the professional hazard that linguists are often prey to: of attributing disproportionally great significance to the linguistic forms used in communication rather than to the processes of negotiation and adaptation in their actual communicative use.
} 
disso, o repertório multilíngue do falante passou a ser visto sem uma divisão clara entre as línguas.

Em suma, essas redefinições de objetivos de estudo no campo do ILF acarretam também uma ressignificação do conceito de ILF, evidenciando a multiplicidade de sentidos presente no termo. As diferenças encontradas entre cada definição referem-se, principalmente, à inclusão ou não de falantes nativos nas interações em ILF; à importância dada ao aspecto formal da língua ou à produção e negociação de sentidos; à crença na possibilidade de descrever e codificar as variantes de ILF ou o entendimento de ILF como um uso híbrido e fluido da língua; e à ênfase exclusiva no inglês como a língua de comunicação escolhida em contexto de língua franca ou a valorização dos diferentes repertórios linguísticos dos falantes. Como já colocado ao longo do texto, embora os estudos sobre ILF tenham incorporado mudanças significativas nas suas duas primeiras fases, o estudo dos indícios presentes nas definições do conceito nos permite afirmar que a postura diante do conhecimento e da língua permaneceram as mesmas, reproduzindo uma herança epistemológica moderna/colonial.

\subsection{Vozes de 'outras Europas'}

Além das autoras citadas na seção anterior, outros pesquisadores de diversos países também têm desenvolvido estudos sobre ILF em seus contextos. Mencionamos aqui alguns deles a fim de compreender que entendimentos de ILF embasam esses trabalhos e que temas são abordados nessas pesquisas.

Cavalheiro (2020), pesquisadora portuguesa sobre o tema, define ILF como o inglês "falado em situações com combinações amplamente variáveis de participantes, incluindo falantes de primeiras línguas com diferentes variantes" ${ }^{\circ 7}$ (MAURANEN, 2018, p. 8 apud CAVALHEIRO, 2020, p. 33). Assim como Siqueira (2015, 2018) e Gimenez, Calvo e El Kadri (2015, 2018), que comentaremos adiante, Cavalheiro (2020) também articula ILF à possibilidade de promover trocas e diálogos interculturais e enxerga a sala de aula de língua inglesa como espaço de integração de estudantes migrantes. Para isso, defende o que chama de small-culture approach, "na qual é dada atenção ao fomento de uma comunicação multilíngue intercultural efetiva; consequentemente, encorajando as interações interpessoais entre pessoas de diferentes repertórios culturais" 58 (CAVALHEIRO, 2020, p. 37).

\footnotetext{
${ }^{57}$ [...] spoken in situations with widely varying combinations of participants, including first-language speakers of different varieties.

${ }^{58}[. .$.$] where attention is given to fostering effective intercultural multilingual communication; hence, encouraging$ interpersonal interactions between people from different cultural backgrounds.
} 
Para a autora, as noções de comunicação, cultura, identidade e língua associadas a ILF devem ser vistas como emergentes, adaptáveis, construídas e negociáveis. Quando analisa atividades desenvolvidas em salas de aula portuguesas com alunos migrantes, ela cita uma atividade em que personagens de diferentes países são representados como falantes de língua inglesa, como indianos e chineses, cujas falas com sotaques característicos de cada uma dessas variantes são geradas a partir de um aplicativo online de construção de avatares. Outra atividade analisada pela pesquisadora incluía diferentes perspectivas sobre uma mesma data comemorativa, no caso a Páscoa. Para alunos mais velhos e com maior conhecimento sobre a língua, as diferentes estratégias que os alunos lançaram mão para se comunicarem com alunos de outros países foram consideradas, como paráfrase, code-switching, reescrita, uso de imagens, dentre outras.

A partir desses exemplos, podemos identificar quais conceitos de ILF estão refletidos em cada atividade e constituem a perspectiva da pesquisadora. A representação de falantes de inglês de diferentes países reflete um entendimento de ILF que se aproxima ao paradigma de WE, uma vez que a noção de variantes é considerada, o que aponta para um entendimento do conceito com delimitações claras entre seus usos e de acordo com a nacionalidade, lembrando as fases iniciais dos estudos de ILF comentadas na seção anterior do trabalho. Na atividade sobre a Páscoa, ILF é articulado ao conceito de interculturalidade, ao discutir as diferentes perspectivas culturais sobre um mesmo evento. Por fim, ao tratar das estratégias de comunicação utilizadas nas interações entre falantes, o conceito se aproxima de entendimentos mais recentes de ILF, uma vez que diferentes recursos, linguísticos e visuais, são considerados para a negociação de sentidos, alinhado a uma perspectiva da translinguagem, embora a autora não utilize esse conceito.

Em Guerra et al. (2020), um estudo comparativo sobre materiais didáticos para o ensino de língua inglesa é conduzido por pesquisadores de Portugal, como Guerra, Pereira e Cavalheiro, e da Turquia, como Kurt, Oztekin, Sonmez-candan e Bayyurt, a fim de analisar se os diferentes usos do inglês nas comunicações internacionais são considerados em materiais utilizados nesses dois países. Para essa análise, os autores afirmam que se baseiam nos paradigmas de ILF, ILI e WE. De fato, a noção de variantes é trazida por eles diversas vezes ao longo do estudo, com forte delimitação entre elas, apontando para uma concepção de ILF como nas fases iniciais do campo. Eles concluem que ainda há uma predominância de variantes hegemônicas nesses materiais e pouca alusão aos usos internacionais do inglês e uma perspectiva de ILF. 
Sifakis (2019), pesquisador grego sobre o tema, compreende ILF não como uma variante passível de codificação, mas como um modo ou caminho, em que o foco recai sobre o contexto de comunicação, sobre os usuários de ILF e sobre as variadas estratégias de comunicação. Embora o autor mencione as discussões sobre translinguagem, ele também assume uma visão pautada no ensino de diversas variantes e no uso de corpora para exemplificar interações de sucesso, sugerindo uma aproximação com entendimentos de ILF que percorreram as diversas fases de estudo do conceito.

Ele defende uma integração entre a perspectiva de ILF e a sala de aula de ILE. Para isso, propõe que os professores sejam formados para desenvolverem o que ele chama de $E L F$ awareness, uma tomada de consciência sobre ILF, definida como:

[...] o processo de se engajar com as pesquisas em ILF e desenvolver seu entendimento dos modos pelos quais elas podem ser integradas em seu contexto de ensino, através de um processo contínuo de reflexão crítica, design, implementação e avaliação das atividades instrucionais que refletem e localizam sua interpretação sobre o construto ILF $^{59}$ (SIFAKIS; BAYYURT, 2018, p. 459 apud SIFAKIS, 2019, p. 290-291).

Segundo o autor, chegar a essa tomada de consciência significa conhecer as discussões e pesquisas a respeito de ILF para que se incorpore na prática aquilo que for possível dentro das particularidades de cada contexto, enfatizando a noção de atitude de cada um dos envolvidos no processo de aprendizagem, sejam professores, desenvolvedores de currículo ou materiais, formadores, avaliadores, dentre outros atores sociais relevantes.

Na Itália, Lopriore e Vettorel (2015) analisam a influência das perspectivas de WE e ILF em materiais didáticos italianos para ensino de inglês, constatando a ausência de falantes não-nativos representados como falantes legítimos da língua. As autoras identificam um aspecto positivo em relação às propostas que objetivam promover consciência intercultural nos materiais analisados, que incluem elementos de diferentes países e diferentes contextos linguístico-culturais, inclusive para promover a reflexão do aprendiz sobre sua própria cultura. Nota-se, entretanto, a ausência de atividades que propõem o uso de estratégias comunicativas, que elas consideram ser fundamentais no ensino de língua inglesa para interação em contextos de WE e ILF.

Elas enfatizam que adotar uma perspectiva baseada em WE e ILF não significa implementar um modelo pedagógico prescritivo, selecionando aspectos e traços linguísticos que devem ser ensinados ou mesmo escolher uma das inúmeras variantes linguísticas ou uma

\footnotetext{
${ }^{59}[. .$.$] the process of engaging with ELF research and developing one's own understanding of the ways in which$ it can be integrated in one's classroom context, through a continuous process of critical reflection, design, implementation and evaluation of instructional activities that reflect and localize one's interpretation of the ELF construct.
} 
variante internacional. Tal abordagem significa ir além de uma visão monolítica de língua e cultura, o que implica uma mudança de perspectiva e que "“permitiria a cada aprendiz e falante de inglês refletir sobre sua própria realidade sociolinguística, em vez daquela de um distante falante nativo' (Jenkins, 2006a, p. 173) e sobre cada contexto local de aprendizagem e uso"60 (LOPRIORE; VETTOREL, 2015, p. 17).

Para a produção de materiais e propostas de atividades, elas recomendam que os aprendizes devam ser expostos a contextos reais de uso da língua em contexto de ILF, em que os modelos para os aprendizes não sejam os falantes nativos, mas sim falantes inteligíveis, através de, por exemplo, notícias de encontros internacionais com a presença de figuras públicas não-nativas. Sugerem também atividades que desenvolvam a percepção linguística dos aprendizes através do uso de estratégias de negociação e co-construção de sentidos. Defendem que os professores em formação devam ser encorajados a produzir seus próprios materiais, fazendo uso de recursos disponíveis online de contextos reais de uso da língua. Mas para além da simples exposição da pluralidade de 'ingleses', importa observar como essa pluralidade é apresentada através de tarefas e atividades desafiadoras que ultrapassam o contexto escolar.

Para que isso ocorra, é preciso uma mudança de concepção de aluno e de língua. Esse aprendiz deve ser considerado capaz de se apoiar em seu repertório multilíngue e se tornar um agente de mudança. E a língua deve ser concebida como:

[...] um sistema complexo e adaptativo (Ellis and Larsen-Freeman 2009: 4), uma variedade política (Seidlhofer et al. 2006; Seidlhofer 2011), na qual a mudança linguística é um fenômeno natural e a competência linguística dos aprendizes inclui sua habilidade em dispor se sua identidade como membro de uma comunidade (Canagarajah 2007b). Em resumo, uma visão do inglês como um construto discursivo (Widdowson 2003). É em meio a essa visão que ILF desafia todas as representações tradicionais anteriores de variantes linguísticas uma vez que 'opera através de fronteiras sociolinguísticas convencionais em vez de operar no interior delas' (Cogo and Dewey 2012: 165) ${ }^{61}$ (LOPRIORE; VETTOREL, 2015, p. 21).

O sentido de ILF trazido pelas autoras parece não se ancorar nas fronteiras entre variantes nem se resume à exposição a diferentes usos da língua, mas sim a uma conscientização sobre esses usos e o que é feito para que se chegue à compreensão.

\footnotetext{
${ }^{60}$ [...] one that 'would enable each learner's and speaker's English to reflect on his or her own sociolinguistic reality, rather than that of a usually distant native speaker' (Jenkins 2006a: 173) and to each local context of learning and use (p. 17).

${ }^{61}$ [...] a complex and adaptive system (Ellis and Larsen-Freeman 2009: 4), a polylithic variety (Seidlhofer et al. 2006; Seidlhofer 2011), in which language change is a natural phenomenonm and learners' language competence includes their ability to display their identity as member of a community (Canagarajah 2007b). In short, a view of English as a discursive construct (Widdowson 2003). It is within this view that ELF defies all previous traditional representations of language varieties since it 'operates across conventional sociolinguistic boundaries rather than within them' (Cogo and Dewey 2012: 165)
} 
Ao ouvirmos essas outras vozes europeias sobre ILF, identificamos semelhanças no modo de conceber ILF em relação às definições fornecidas por Jenkins (2000, 2005, 2006a, 2006b, 2009, 2015, 2017) e Seidlhofer (1999, 2001, 2005, 2009), analisadas na seção anterior. No geral, os entendimentos desses autores refletem muitos dos sentidos das diferentes fases do campo de estudos em ILF, como, por vezes, equiparando ILF e WE e ancorando-se nas noções de variantes delimitadas geograficamente, e outras questionando tais delimitações, fazendo com que diferentes concepções coexistam. Entretanto, tais pesquisas expandem as questões conceituais e linguísticas para a dimensão pedagógica, investigando como essa perspectiva teórica pode refletir nos contextos de ensino de língua inglesa, olhando para as práticas desenvolvidas em sala de aula, para os materiais didáticos utilizados e para a formação de professores.

\subsection{ILF made in Brazil: vozes do Sul Global}

Embora o ILF seja um campo de estudos já consolidado internacionalmente, são recentes as pesquisas nacionais que se debruçam sobre essa perspectiva. Bordini; Gimenez (2014) constatam um crescimento expressivo na quantidade de artigos, capítulos de livros, dissertações e teses locais sobre o tema entre 2008 e 2011, o que sugere um interesse cada vez maior de pesquisadores brasileiros por essa área. Desde então, ainda mais trabalhos sobre esse paradigma vêm sendo publicados, como é o caso de Gimenez, Calvo e El Kadri (2015, 2018), Siqueira (2015, 2018), Jordão e Marques (2018), Duboc (2018), Jordão (2019) e Duboc e Siqueira (2020).

Interessa-nos aqui observar como o conceito de Inglês como Língua Franca está sendo apropriado e ressignificado no campo teórico brasileiro. Para isso, nos dedicamos à tentativa de identificar, a partir do lócus de enunciação de algumas dessas pesquisas, (i) como o conceito de ILF é definido, (ii) a concepção de língua que embasa o entendimento desse conceito e (iii) as implicações desses aspectos nas propostas de formação de professores de inglês, de produção de materiais e de ensino de língua inglesa.

Gimenez, Calvo e El Kadri (2015), Siqueira (2015), Jordão e Marques (2018), Duboc (2018) e Jordão (2019) partem de uma perspectiva crítica para analisar o fenômeno do ILF. Convergem em uma compreensão do conceito não enquanto uma variante, mas sim um uso do inglês como língua de contato por falantes que não compartilham o mesmo repertório linguístico e cultural.

Gimenez, Calvo e El Kadri (2015) referem-se a Seidlhofer (2011) para conceituar ILF, entendendo-o como "qualquer uso do inglês entre falantes de diferentes primeiras línguas, para 
quem o inglês é o meio comunicativo escolhido, e frequentemente a única opção"62 (SEIDLHOFER, 2011, p. 7 apud GIMENEZ; CALVO; EL KADRI, 2015, p. 225). Assim como Gimenez, Calvo e El Kadri (2015), Siqueira (2015) se apoia na mesma definição de Seidlhofer (2011) para definir o conceito de ILF, além de Jenkins (2007), entendendo-o como o uso do inglês como língua de contato por falantes que não compartilham o mesmo repertório linguístico e cultural. Duboc (2018) traz as definições de Jenkins (2006, 2009) e Seidlhofer (2001) para conceituar ILF, acrescentando que falantes nativos também são considerados pelas autoras, mas não são as suas normas linguísticas que prevalecem em contexto de língua franca.

Para além desse entendimento, Jordão e Marques (2018, p. 55) o definem como:

[...] um contexto específico de uso da língua que produz formas linguísticas e modos de interação e comunicação marcadamente diferentes daqueles esperados de contatos de interação tradicionais (aqueles que tomam o construto 'falante nativo' como uma referência absoluta). Conceituado como um contexto específico de uso da língua, ILF significa Inglês usado como uma língua franca, entre falantes multilíngues em práticas contextualizadas. ${ }^{63}$

Ao referir-se a um contexto de uso da língua por falantes multilíngues em práticas contextualizadas, tal definição demonstra não só uma compreensão da língua como prática social, mas também reconhece os outros repertórios linguísticos desses falantes ao tratá-los como multilíngues. Às definições anteriores de ILF, Jordão e Marques (2018) parecem adicionar mais uma dimensão a essa concepção, pois vão além do uso que se faz da língua, considerando também os recursos extra-linguísticos na interação e a dependência do contexto comunicativo, entendido por eles não apenas como o espaço físico e os graus de formalidade a serem empregados, mas também como "dimensões afetivas, históricas, cognitivas, espaciais, perceptivas, materiais, representacionais de nossas ontologias e epistemologias, de como os interlocutores entendem e portanto têm suas práticas interacionais construídas" ${ }^{64}$ (JORDÃO; MARQUES, 2018, p. 55).

Siqueira (2015) enfatiza o caráter desterritorializado desses usos, de seus múltiplos contextos e propósitos comunicativos. Dessa maneira, o foco recai sobre a comunicação, considerando a língua não como meio, mas sim como consequência, adaptando-se às necessidades daqueles que a utilizam (SIQUEIRA, 2018). Além disso, em oposição a um ensino

\footnotetext{
62 [...] any use of English among speakers of different first languages for whom English is the communicative medium of choice, and often the only option.

63 [...] a specific context of language use that produces language forms and ways of interacting and communicating markedly different from those expected from traditional interaction contacts (those taking the construct "nativespeaker" as an absolute reference). Conceptualized as a specific context of language use, ELF means English used as a lingua franca, among multilingual speakers in contextualized practices.

64 [...] affective, historical, cognitive, spatial, perceptual, material, representational dimensions of our ontologies and epistemologies, of how interlocutors understand and thus have their interactional practices constructed.
} 
pautado na visão de ILE, a perspectiva de ILF foca em estratégias de comunicação e "pode contribuir para uma maior atenção às necessidades locais e para a construção da identidade de um aprendiz mais crítico" (CALVO; EL KADRI, 2011, p. 34 apud SIQUEIRA, 2012, p. 141).

Assim como Siqueira (2015), Gimenez, Calvo e El Kadri (2015) também acreditam que um ensino pautado na perspectiva do ILF seria capaz de instigar o desenvolvimento de uma consciência crítica nos aprendizes, voltando-se para questões de interesse global que permitem ir "além da Madonna", fazendo alusão a lugares comuns no ensino de inglês embasado em uma abordagem de ILE.

Contrastando também as perspectivas de ILF e de ILE, Duboc (2018) lembra que ao primeiro acrônimo estão relacionadas noções como inteligibilidade, pluricentrismo, variação, localidade, hibridismo, acomodação e diferença, enquanto o segundo remete a noções como precisão, monocentrismo, erro, padronização, purismo, imitação e deficiência.

Os autores também partem de uma concepção mais aberta e dinâmica de língua. Siqueira (2018) se distancia da visão estruturalista tradicional de língua como um sistema fixo e uma entidade monolítica e passa a compreendê-la como prática social plural, híbrida e fluida. Desse modo, a língua se torna "muito mais que um objeto de ensino, mas a ponte, a dimensão mediadora entre sujeitos culturais e mundos, cujo foco recai em meio a relações dialógicas, em meio ao lugar de interação"65 (MENDES 2011, p. 140 apud SIQUEIRA, 2018, p. 100).

Em sua discussão sobre ILF, Jordão e Marques (2018) partem das teorias sobre Letramento Crítico e Pós-humanismo. A partir desse lócus, o ensino e a aprendizagem de línguas passam a promover espaços de negociação de sentidos, reconhecendo, assim como Siqueira (2017), contradições e conflitos como aspectos importantes desse processo. A língua é entendida como discurso, em que sentidos são negociados de forma aberta, situada e contingente. Nesse sentido, a norma é recriada em cada contexto de prática. Isso não significa que cada indivíduo estabelece a sua norma. Em vez disso, a norma é:

[...] constantemente traduzida, reinterpretada, reescrita, associada e ressignificada em
relação a outras histórias individuais e coletivas, regularidades esperadas e normas
culturais. Cada situação de uso da língua é constituída por múltiplos repertórios
(Pennycook 2014) ou recursos que cada participante traz para a cena. E mais: a
dimensão não-humana da interação também precisa ser levada em conta na interação
como uma dimensão ativa de comunicação ${ }^{66}$ (JORDÃO; MARQUES, 2018, p. 59,
grifos dos autores).

65 [...] much more than an object of teaching, but the bridge, the mediating dimension between cultural subjects/worlds [whose] focus lies within the dialogical relationships, within the place of interaction.

${ }^{66}$ [...] constantly translated (Bhabha 1994), reinterpreted, rewritten, associated and resignified in relation to other individual and collective histories, expected regularities and cultural norms. Each situation of language use is constituted by multiple repertoires (Pennycook 2014) or resources that each participant brings to the scene. 
Baseados na perspectiva pós-estruturalista de Foucault (1983, 2002), os autores entendem a língua em suas relações de poder, com mecanismos que legitimam determinados significados e excluem outros. Eles negam uma concepção que acredita na transmissão de significados, preferindo uma que os considera como contingentes, ou seja, relacionados às circunstâncias que os produziram. Diferente de um paradigma tradicional de ILE, que considera que a aprendizagem prévia de estruturas garantiria a transmissão de significados, uma perspectiva de Letramento Crítico considera que significados são atribuídos aos textos, e não extraídos deles.

A partir desse entendimento de língua, eles também mencionam a noção de recursos, que podem ser trazidos à situação de uso da língua. Tais recursos modificam-se de acordo com o contexto de uso e de quem os usa. Portanto, não podem ser formulados previamente e ativados em determinados contextos. Nessa perspectiva, a língua é vista como constituída de agência, definida como "qualquer coisa que modifica um estado de coisas fazendo alguma diferença" 67 (LATOUR, 2005, p. 71 apud JORDÃO; MARQUES, 2018, p. 61). Sendo assim, numa interação em ILF, os falantes trazem à tona recursos de seus diferentes repertórios linguísticoculturais, negociando e produzindo sentidos. As normas comunicacionais são ali construídas e permitem que a interação ocorra. Além disso, os autores lembram que, quando usamos a língua, trazemos nossas "personalidades, experiências, emoções, culturas, histórias e visões políticas"68 (JORDÃO; MARQUES, 2018, p. 65) que permitem que conexões sejam feitas e significados sejam produzidos. Compreender a interação de tal forma dialoga com o entendimento de Busch (2012, 2017) sobre repertório linguístico. Por isso, nos deteremos brevemente sobre esse conceito para então prosseguirmos.

Amplamente debatido nos estudos sobre translinguagem atualmente, o conceito de repertório linguístico, de acordo com Busch (2012, 2017), distancia-se da ideia de língua como estrutura, sistema e regularidade e aproxima-se às noções de fluidez e criatividade nas práticas linguísticas. Tal noção traz à tona a preocupação com os sentidos produzidos na interação e com os recursos nela utilizados, mais do que por quais e quantas línguas são faladas e o nível de proficiência em cada uma delas. Considera que a trajetória dos indivíduos constroem os seus repertórios, refletindo o tempo presente e passado, suas vidas vividas local e globalmente.

\footnotetext{
And more: the non-human dimension of the interaction also needs to be taken into account as an active dimension of communication.

${ }^{67}$ [...] anything that does modify a state of affairs by making a difference.

68 [...] personalities, experiences, emotions, cultures, histories, political views [...].
} 
Preocupa-se também em compreender como o sentimento de pertencimento, diferença, exclusão e inclusão são construídos a partir e por conta da língua.

Segundo a autora, esse conceito, elaborado inicialmente por Gumperz (1964 apud BUSCH, 2012, 2017) a partir de uma perspectiva externa dos falantes e de seus comportamentos linguísticos, parte da ideia de comunidades relativamente estáveis de fala, nas quais o indivíduo faz suas escolhas linguísticas a partir das convenções sociais de sua comunidade e seus modos aceitáveis de produzir sentido, compondo seu repertório linguístico. Com o fenômeno da super diversidade, em que as relações sociais e as práticas linguísticas se tornam mais complexas devido à grande mobilidade global, a ideia de comunidades estáveis de fala, na qual Gumperz (1964 apud BUSCH, 2012, 2017) se baseou, é alterada, pois elas se tornam temporárias e os falantes fazem parte de várias delas, trazendo mudanças no conceito.

Busch (2012, 2017) revisita e expande a noção de repertório, baseando-se nas contribuições do pós-estruturalismo e explorando o que ela chama de experiência vivida de língua, assumindo uma perspectiva subjetiva que leva em consideração o corpo, o sentimento, a percepção, a experiência e o desejo, além da dimensão histórica e biográfica dos sujeitos. Importa enfatizar que o repertório linguístico não é algo estático, ele se desenvolve e muda ao longo das interações e experiências vividas, sejam elas positivas ou negativas. A recorrência de experiências, vividas emocional e corporalmente, torna-se parte do repertório do sujeito, influenciando suas atitudes nas práticas linguísticas, assim como mencionam Jordão; Marques (2018).

Articulado ao conceito de ILF, Gimenez, Calvo e El Kadri (2015) e Siqueira (2015, 2018) discutem o conceito de interculturalidade. Para as primeiras autoras, uma consciência intercultural se faz necessária como forma de lidar com diferentes formas de produzir sentidos e com possíveis desentendimentos culturais, em vez de promover uma visão monolítica de cultura ao associar o uso da língua apenas a determinadas culturas e países.

Siqueira $(2015,2018)$ também defende uma abordagem intercultural no ensino de ILF, a fim de deslocar os usos e os usuários de variantes não-hegemônicas da língua do lugar periférico, ou mesmo invisível, que ocupam. Segundo o autor, a interculturalidade abarca aspectos como a interação efetiva entre pessoas de culturas diferentes; as relações entre culturas com o objetivo de enriquecer umas às outras e o estabelecimento de pontes entre culturas a fim de alcançar modos mais respeitosos e democráticos de vida (SIQUEIRA, 2018). Embora concorde com o caráter positivo e solidário de respeito às diferenças nesses diálogos interculturais, ele lembra que tais trocas não se dão de forma pacífica e sem conflitos, uma vez que são inerentes a qualquer interação entre diferentes. 
Partindo de uma visão crítica da pós-modernidade, Duboc (2018) propõe que algumas noções sejam revisitadas a partir da perspectiva de ILF, tais como a ideia de comunicação, de falante nativo e a visão romântica nas interações entre falantes nativos e não-nativos.

Para a autora, entender a comunicação do mesmo modo como foi concebida na modernidade através da Linguística, em seu caráter instrumental de expressão da realidade, não é mais suficiente. Tampouco a visão sociológica é capaz de contemplar a complexidade da sociedade global contemporânea. Embora conceba língua como discurso, tal visão ainda se prende a uma visão normativa das funções comunicativas. Sendo assim, ela propõe uma revisão nos conceitos de comunicação e de língua, nos quais a noção de agência se mostra fundamental para o mundo global e digital contemporâneo, no qual novos modos de produção de sentido são criados. Duboc (2018) sugere que a noção tradicional de língua como meio de comunicar informações e ideias deve ser expandida para uma noção de língua como meio de agenciamento crítico e de mobilização, de acordo com o interesse do sujeito.

Ao rever os tradicionais conceitos de comunicação e língua, a autora lança também um novo olhar sobre o conceito de ILF, quando afirma que para além da usual definição de ILF como uma língua que serve como meio de comunicação entre falantes de diferentes primeiras línguas, os estudos em ILF devem também questionar os motivos pelos quais os sujeitos se comunicam.

No que se refere ao construto do falante nativo, Duboc (2018, p. 169) alerta para o risco de generalizações nas discussões de ILF, trazendo as seguintes problematizações:

[...] se os estudos em ILF estão realmente preocupados com os usos criativos, locais e híbridos do inglês em práticas comunicativas em curso entre pessoas de todo o mundo, ainda importa mencionar o falante nativo nos estudos em ILF? Se a agenda linguística deve ser estabelecida em cada prática comunicativa entre falantes de ILF em uma base democrática e inclusiva, não poderia o falante nativo também definir a agenda dependendo de quem ele é e qual atitude ele traz para o encontro com o outro? ${ }^{69}$

A autora esclarece que ainda é preciso resistir à centralidade do falante nativo nas definições das normas linguísticas. Entretanto, ela insiste que não é possível universalizar a noção de falante nativo como se todos eles agissem da mesma maneira na interação. Ela recupera a ideia do falante nativo como um mito (PENNYCOOK, 2010 apud DUBOC, 2018), construído com base em uma visão estereotipada, estática e pronta. Como forma de evitar que o falante não-nativo se torne o centro às custas da marginalização do nativo, o que acarretaria

69 [...] if ELF studies are truly concerned with the creative, local and hybrid uses of English in current communicative practices among people from all over the world, would it still matter to mention the native speaker in ELF studies? If the linguistic agenda is to be set in the very communicative practices among ELF speakers on a democratic, inclusive basis, couldn't the native speaker be also an agenda setter depending on who they are and what attitude they bring in their encounters with the other? 
uma contradição da abordagem pós-moderna do descentramento, Duboc (2018) propõe uma perspectiva dialógica no que se refere às interações entre eles em vez de considerá-los como conceitos estáveis.

Por fim, a autora questiona a visão romântica de interação no debate sobre ILF, propondo uma agenda crítica que englobe questões ideológicas e as relações de poder entre os usuários de inglês nas situações discursivas, através de questionamentos (DUBOC, 2018, p. 172) que ultrapassam a clássica dicotomia no campo entre nativos e não-nativos:

Em que medida os participantes de ILF estão conscientes de sua própria agenda sobre ILF? Em que medida eles estariam dispostos a conceber ILF como uma língua e um fenômeno cultural legítimo (Rajagopalan 2011) como forma de ir além da (auto)marginalização? De quem é o veredito que conta na hora de interpretar uma certa escolha linguística (seja ela de natureza fonológica, lexical, gramatical ou pragmática) como erro ou variação? Quem se ajusta a quem? Quem se acomoda a quem? ${ }^{70}$

Em estudos mais recentes, autores brasileiros como Jordão (2019) e Duboc e Siqueira (2020) têm se alinhado ao pensamento decolonial para refletir sobre ILF. Jordão (2019), por exemplo, ressignifica o conceito de proficiência à luz dessas teorias. Trazendo as ideias de pensamento de fronteira e delinking para o campo da linguística aplicada e do ensino de línguas, a autora defende um afastamento de perspectivas monolíngues nas teorias de aquisição e uma aproximação a uma visão bakhtiniana de língua como prática social, na qual a língua é concebida como socialmente constituída em um processo inacabado de realização, criada em cada ato enunciativo. A língua é vista como uma atividade, e não como um sistema. Além disso, Jordão (2019, p. 40) adota uma perspectiva translíngue segundo a qual:

[...] as línguas são percebidas como interdependentes, mutuamente influenciando umas às outras, em permanente processo de mudança; a fronteira entre duas línguas quaisquer, portanto, são sempre dispersas e nunca rígidas. [...] $\mathrm{Na}$ translinguagem, o sentido é construído através do repertório do sujeito. Um repertório, nesse contexto, não se refere apenas, nem mesmo "principalmente", a elementos linguísticos, mas relaciona-se com todo meio disponível para construir sentido, seja ele visual, gestual, oral, escrito e assim por diante. ${ }^{71}$

Jordão (2019) evidencia a influência moderna/colonial dos nossos métodos e estratégias de ensino de línguas, resultando na noção epistemologicamente violenta de proficiência,

\footnotetext{
${ }^{70}$ To what extent are ELF participants aware of their own ELF agendas? To what extent would they be willing to conceive of ELF as a legitimate language and cultural phenomenon (Rajagopalan 2011) as a way to truly go beyond (self) marginalization? Whose verdict would count towards interpreting a certain linguistic choice (be it of phonological, lexical, grammatical or pragmatic nature) as an error or a variation? Who adjusts to whom? Who accommodates to whom?

71 [...] languages are perceived as interdependent, mutually influencing one another constantly, in permanent process of change; the border between any two languages, therefore, are always blurred and never rigid. [...] In translingualism, meaning is made by making use of one's repertoire. A repertoire, in this context, does not refer only, not even "mostly", to discrete language items, but it relates to every means available for meaning-making, be they visual, gestural, voiced, written and so on.
} 
focando na fala e na fluência e tomando como ideal o construto de falante nativo, perpetuando a violência epistêmica sobre os chamados falantes não-nativos. Para superar essa violência, ela propõe uma descolonização da mente, desconectando o conceito de proficiência de um paradigma monolíngue e inserindo-o em uma perspectiva translíngue, aberta às noções de negociação de sentidos em vez de precisão gramatical e articulada à ideia de inteligibilidade. Nesse sentido, proficiência e inteligibilidade devem ser entendidas como práticas situadas, ressignificadas em cada situação de interação.

Partindo das noções decoloniais de pluralismo epistêmico e co-presença de epistemologias, Duboc e Siqueira (2020) questionam a predominância europeia nos estudos de ILF para que as pesquisas produzidas no Sul Global também se tornem visíveis, lembrando o conceito de pensamento abissal de Sousa Santos (2007), da invisibilidade dos conhecimentos produzidos do outro lado da linha. Com esse objetivo, Duboc e Siqueira (2020) evidenciam a produção nacional sobre o tema enquanto ato político e de resistência, o que Duboc (2019) chama de ILF feito no Brasil. Baseados nos estudos de Letramento Crítico, da Linguística Aplicada Crítica, da Pedagogia Crítica freireana e da Decolonialidade, os autores articulam ao conceito de ILF a natureza crítica e política da língua; as relações de poder e as relações entre sujeito, identidade, cultura, colonialidade e translinguagem.

Esses diversos autores também se debruçam sobre as mudanças que uma perspectiva de ILF deve trazer para o ensino de língua inglesa, especialmente no que diz respeito à produção de materiais didáticos e à formação docente.

Em relação às mudanças na produção de materiais didáticos, Gimenez, Calvo e El Kadri (2015) defendem que recursos didáticos baseados no ILF devem incluir "exemplos de diferentes tipos de interação entre falantes não-nativos, respeitar variantes locais do inglês, desenvolver tolerância às diferenças e promover a diversidade cultural"72 (GIMENEZ; CALVO; EL KADRI, 2015, p. 226).

Elas também dão especial atenção à importância da formação de professores para que se tente diminuir uma lacuna conceitual no campo do ensino de inglês. Ao mesmo tempo em que o uso do idioma é majoritariamente reconhecido em contextos em que assume o papel de língua franca e os estudos no campo do ILF avançam, ainda perduram práticas tradicionais no ensino do idioma nas salas de aula em todo o mundo, pautadas no paradigma do ILE. Nas palavras de Gimenez, Calvo e El Kadri (2018, p. 211-212):

\footnotetext{
72 [...] examples of many different types of interaction between non-native speakers, respect local varieties of English, develop tolerance for differences and promote cultural diversity.
} 
Se, por um lado, temos pesquisadores de linguística aplicada interessados em desenvolver novas ferramentas conceituais para explicar a re-locação do inglês em uma perspectiva pós-colonial, isto é, separando-o de seus falantes nativos históricos, por outro lado temos professores influenciados por um crescente mercado que reforça a ideologia do falante nativo e políticas governamentais que fazem pouco para "mudar o status quo"73.

Segundo elas, o maior desafio em promover uma formação em ILF é lidar com a reconceituação de alguns aspectos no ensino de inglês trazidos por esses estudos, tais como a descentração do modelo do falante nativo, a conscientização intercultural e mudanças no que diz respeito ao modo como pensamos o ensino e a língua, metodologias e materiais, além de crenças e atitudes.

Pautadas nessa necessidade e a fim de desafiar a visão de língua baseada nas normas de falantes nativos predominante no campo do ensino de inglês, Gimenez, Calvo e El Kadri (2015, p. 227) desenvolveram em 2010 uma disciplina de 60 horas para graduandos, cujos objetivos foram:
a) introduzir referências básicas sobre o inglês e sua expansão global,
b) discutir sobre ILF e as implicações do descentramento do falantes nativo como norma,
c) familiarizar os alunos com algumas características gramaticais e discursivas em comunicações transculturais através da análise de corpora de ILF,
d) analisar materiais de ensino de acordo com as discussões acima. ${ }^{74}$

Além disso, incluíram na discussão tópicos como as diferenças entre as perspectivas de ILF e ILE, as implicações da perspectiva de ILF para o ensino e a aprendizagem, e a propriedade do inglês.

Um aspecto chama a atenção em relação a essa proposta. Embora as discussões apresentadas sejam de grande importância para compreender o paradigma do ILF, a elaboração do curso foi baseada no pressuposto de que era necessário optar por um modelo de língua, quando as autoras afirmam que uma das principais decisões sobre o currículo é sobre qual modelo adotar, o que resultou na escolha de expor os alunos a diferentes variantes do inglês, com menos ênfase em modelos dominantes dos Estados Unidos e do Reino Unido.

Esse pressuposto nos remete à crítica que Jordão e Marques (2018) promovem da equiparação feita por alguns estudiosos entre os paradigmas do ILF e do WE. Segundo os

\footnotetext{
${ }^{73}$ If, on the one hand, we have applied linguistics researchers interested in developing new conceptual tools to explain the re-location of English in a postcolonial perspective, i.e. detaching it from its historical native speakers, on the other hand we have teachers influenced by a growing market that reinforces the native speaker ideology and governmental policies that do little to "rock the boat".

74 a) introducing some basic references on English and its global spread, b) discussing ELF and the implications of the de-centering of the native speaker as a norm, c) familiarizing the students with some grammatical and discursive features in transcultural communication through the analysis of ELF corpora, d) analyzing teaching materials according to the discussions above.
} 
autores, embora esses dois campos se aproximem quando enfatizam contextos onde o inglês não é falado como primeira língua e em interações entre falantes não-nativos, em vez de valorizar a adequação a normas pré-estabelecidas, os estudos de WE se distanciam do paradigma do ILF ao priorizarem o estudo da língua com contornos definidos entre as variantes de inglês. Justamente esse foco nas variantes é que parece ter sido enfatizado na proposta de curso de Gimenez, Calvo e El Kadri (2015). Como consequência, a análise das unidades didáticas produzidas pelos alunos do curso mostrou que um de seus entendimentos sobre ILF é de que essa é uma perspectiva sobre as diferentes variantes e sotaques do inglês que devem ser trazidos para a sala de aula. As próprias autoras reconhecem essa aproximação quando consideram que:

Talvez nós possamos gradualmente caminhar de um estágio em que há o reconhecimento da diversidade linguística, como é normalmente associado com o paradigma de 'World Englishes', para um em que há o reconhecimento de que ILF é sobre a dinâmica de usar a língua para se engajar na produção de sentidos ${ }^{75}$ (GIMENEZ; CALVO; EL KADRI, 2015, p. 234).

Essa ponderação é válida também para alguns dos estudos apresentados na seção anterior, como de Cavalheiro (2020) e Guerra et al. (2020), que também se ancoram na noção de variantes e aproximam-se do paradigma de WE.

Além de discordarem da ideia de contornos definidos entre variantes, Jordão e Marques (2018) também criticam as tentativas de descrição linguística, que, segundo eles, consideram a língua como objetos, sistemas autônomos dotados de essência para expressão do pensamento. Eles lembram que a descrição pode vir a estabelecer uma nova norma, que determina o que é certo e errado no uso da língua e cria hierarquias entre as variadas formas linguísticas. Tais determinações e hierarquias são associadas por Jordão e Marques (2018, p. 56) às relações de colonialidade, entendida como:

[...] um sistema de relações desiguais de conhecimento, poder, recursos e autoridade (dentre outros), não restrito ao tempo histórico, mas "controlado e reproduzido em nome do desenvolvimento; [o sistema colonial] define quais conhecimentos são valorizados como conhecimento e estabelece quem é reconhecido como um cidadão pleno e quem não é (Souza 2012)"'. Tal colonialidade é penetrante e sempre presente na linguística aplicada e nas teorias de ensino e aprendizagem de língua, muitas das quais reproduzem perspectivas etnocêntricas de usuários de línguas, idealizados como aprendizes eficientes de língua (Pennycook 2010; Canagarajah 2005). ${ }^{76}$

\footnotetext{
75 Perhaps we can gradually move from a stage where there is the recognition of language diversity, as one would normally associate with the 'World Englishes' paradigm, to one where there is acknowledgment that ELF is about the dynamics of using language to engage in the production of meanings.

76 [...] system of unequal relations of knowledge, power, resources and authority (among others), is not restricted to historical time, but "controlled and reproduced in the name of development; it [the colonial system] defines which knowledges are valued as knowledge and it establishes who is recognized as a full citizen and who is not (Souza 2012)'”. Such coloniality is pervasive and ever-so present in applied linguistics and theories of language
} 
A crítica também se estende ao próprio campo do ILF, em seu objetivo inicial de mapear um núcleo comum de traços fonológicos nas interações em ILF (JENKINS, 2000), também mencionado por Gimenez, Calvo e El Kadri (2015), o que os autores veem como uma tarefa impossível, dadas as mudanças naturais na língua, e indesejável, pois tal núcleo poderia ser interpretado como universal, mas eles já reconhecem que, como afirmam Baker e Jenkins (2015), os esforços nesse sentido já foram deixados de lado (JORDÃO; MARQUES, 2015).

As concepções de língua e ILF, relacionadas às perspectivas de Letramento Crítico e Pós-humanismo, trazidas por Jordão e Marques (2018) implicam “se livrar” de antigos hábitos persistentes no campo do ensino de inglês e de formação de professores. Uma vez que passamos a entender que significados são produzidos, negociados e construídos durante o uso, o ensino que almeja a internalização de estruturas pré-formuladas ou situações comunicativas préestabelecidas perde o seu sentido. Os autores então defendem um ensino que privilegie encontros com situações de construção e negociação de sentidos em inglês, valorizando a inteligibilidade. Além disso, é necessário atentar para a produção de materiais cuja concepção de língua permita a prática de produção de significados e também analisar até que ponto essas concepções reforçam visões normativas do que é considerado como válido em inglês, principalmente através do que é omitido e excluído.

O professor, então, não é mais um mero transmissor, como se houvesse uma realidade pronta a ser transmitida de forma inalterada e neutra. De um papel intermediário na relação do aluno com o conhecimento, o professor passa a ser um mediador. Nesse sentido, afirmam os autores, é possível que os professores de inglês nunca tenham, de fato, ensinado a língua padrão, mas sim “ingleses transformados, traduzidos, distorcidos, modificados ou, como nos disse uma vez um professor, eles devem estar ensinando, na verdade, 'o inglês que eles podem",77 (JORDÃO; MARQUES, 2015, p. 65, ênfases no original).

Siqueira (2018) também reflete sobre as implicações que uma perspectiva de ILF teria para o ensino. Ele chama a atenção para a necessidade de mudanças profundas no ensino do idioma e na formação de professores, o que requer um rompimento com práticas há muito tempo cristalizadas na área. Ele defende a necessidade de uma quebra epistêmica (Kumaravadivelu, 2012) com tradições pedagógicas com visões ocidentais, provenientes do norte global, com seus métodos, materiais, avaliações, dentre outros aspectos.

teaching and learning, most of which reproduce ethnocentric perspectives of monolingual users, idealized as efficient language learners (Pennycook 2010; Canagarajah 2005).

77 [...] transformed, translated, distorted, modified Englishes or, as a teacher once told us, they may have been teaching, in fact, "the English they can". 
Sendo assim, Siqueira (2018) argumenta a favor da necessidade da formação intercultural de professores de línguas, que lidem com questões como identidade, poder, conflitos raciais, mudança social e mobilidade global. Ele vai além ao defender a formação intercultural crítica desses professores, que compreenda os diferentes tipos de inglês nas interações em ILF. Ele almeja um profissional disposto a implementar práticas pedagógicas empoderadoras e a agir e buscar soluções locais para seus desafios, que seu ensino seja orientado à promoção de uma justiça social, formando cidadãos que questionem criticamente as desigualdades existentes.

Para Siqueira (2018), essa formação intercultural só será alcançada através de uma mudança de atitude, que se afaste da visão utilitarista que permanece no campo há tanto tempo e se retire da posição subalterna de usuários não-nativos da língua, na qual fomos colocados por centros coloniais de poder hegemônico.

Essa mudança de atitude proporcionará um professor mais preparado e disposto para lidar com os desafios reais e atuais do ensino de inglês, que se engaje na produção de uma epistemologia autóctene e se liberte da dependência de sistemas hegemônicos de ensino de línguas.

No que diz respeito à produção de materiais didáticos, o autor percebe que há ainda poucas referências em questão de materiais cuja perspectiva seja pautada no ILF (JENKINS, 2012), prevalecendo referências ainda ancoradas nas normas dos falantes nativos, principalmente de estadunidenses e britânicos, e em representações culturais provenientes desses países, conforme análise de livros didáticos desenvolvida por ele (SIQUEIRA, 2015). Entretanto, para o autor, a falta de materiais que considerem o inglês em seu uso como língua franca não deve ser vista como um obstáculo para a adoção dessa perspectiva, pois como afirma Seidlhofer (2011, p. 201 apud SIQUEIRA, 2015, p. 252), “o que é crucial não é que materiais de ensino usamos, mas como os usamos"78, o que nos remete à noção de atitude.

Siqueira (2015) reafirma a legitimidade que falantes de ILF possuem de se apropriarem dessa língua global, remodelando-a conforme as suas necessidades e exigindo, inclusive, que sejam representados em materiais didáticos:

Precisamos nos sentir empoderados a fim de cuidar das invisibilidades, as ausências, as exclusões nas quais nós frequentemente criamos ou ignoramos em meio à nossa rotina de práticas de ensino de língua pelo mundo. Devemos lutar para retomar nossa

78 [...] what is crucial is not what teaching materials are used but how they are used. 
autoestima, nos vermos como donos legítimos da língua inglesa [... $]^{79}$ (SIQUEIRA, 2015, p. 253).

Além disso, ele critica a distância entre o mundo real e aquilo que é veiculado através de livros didáticos, o que ele denomina como "o mundo plástico" (SIQUEIRA, 2010), contribuindo para tornar a sala de aula de língua inglesa uma "ilha da fantasia" ou uma "Disneylândia pedagógica" (SIQUEIRA, 2015, p. 244).

Siqueira (2015) ressalta o caráter ideológico presente nos livros didáticos. Longe de estarem isentos de qualquer influência e pretenderem apenas transmitir estruturas linguísticas, tais materiais têm como objetivo promover a aculturação de seus aprendizes e a sua subjugação às ideologias que a língua carrega.

O autor então defende a necessidade de mudanças no campo do ensino de inglês a fim de se distanciar de práticas que reforçam essa herança colonialista e se aproximar das novas realidades locais no uso da língua, adotando uma visão mais pluralista e pluricêntrica, o que significa que tanto os programas de formação quanto os materiais promovam a consciência intercultural e dialoguem com questões do 'mundo real' dos aprendizes e suas necessidades.

Para pensar as implicações de um ensino baseado na perspectiva do ILF, Duboc (2018) recorre às contribuições de estudiosos da pós-modernidade, destacando as noções de pensamento fraco (VATTIMO, 1987, 2004 apud DUBOC, 2018), educação imperfeita (TODD, 2009 apud DUBOC, 2018) e pedagogia da interrupção (BIESTA, 2006, 2010 apud DUBOC, 2018).

Como comenta Duboc (2018), quando propõe a ideia de pensamento fraco, o filósofo italiano Gianni Vattimo (1987, 2004 apud DUBOC, 2018) rejeita a crença em uma verdade universal, cara ao pensamento moderno, para entendê-la como uma perspectiva situada em determinado contexto e passível de interpretação. Todd (2009 apud DUBOC, 2018), por sua vez, sugere uma educação baseada na perspectiva da imperfeição, que abarque a diferença, a pluralidade, os conflitos e as contradições característicos da complexa sociedade contemporânea. Por fim, no lugar de uma pedagogia normativa, estável e previsível, Biesta (2006, 2010 apud DUBOC, 2018) prefere uma que vá justamente romper com o normal e o esperado, interrompendo modos de pensar e agir.

Para um ensino baseado em ILF, tais contribuições implicam o enfraquecimento de construtos universalizantes como erro, imitação e deficiência para dar lugar a termos mais

\footnotetext{
${ }^{79}$ We need to feel empowered in order to take care of the invisibilities, the absences, the exclusions which we regularly foster or ignore throughout our daily ELT practices around the planet. We should struggle to bring back our self-esteem, see ourselves as legitimate owners of the English language [...]
} 
relativos como variação, acomodação e diferença. Além disso, permite discutir situações comunicativas em que os conflitos e as contradições presentes nas relações humanas se façam presentes, indo além de situações triviais propostas por materiais didáticos. Em consonância com uma pedagogia imprevisível como a de Biesta (2006, 2010 apud DUBOC, 2018), Duboc (2018) apresenta ainda sua ideia de atitude curricular, na qual o professor é capaz de agir entre as brechas a fim de intervir criticamente para promover transformação; ou seja, momentos férteis que identificamos em sala de aula para expandirmos perspectivas.

Quando comparamos diferentes perspectivas sobre ILF e colocamos diversos autores em diálogo como fizemos acima, percebemos que, através de seus loci de enunciação, o modo como cada um deles constrói seus sentidos sobre ILF influencia naquilo que os pesquisadores consideram que deve ser priorizado no ensino de inglês, na formação de professores e na produção de materiais didáticos.

Por fim, é possível afirmar que a apropriação local do conceito de ILF por esses autores brasileiros promove a sua ressignificação, o que Duboc (2019) tem chamado de ILF made in Brazil, uma vez que alguns pesquisadores o articulam a aspectos não considerados pelos seus precursores do norte global, principalmente na perspectiva crítica que adotam, na ênfase às noções de agência e atitude, e sua preocupação com as questões de poder no uso da língua, não só na relação entre nativos e não-nativos, que é inclusive desconstruída por alguns dos autores, mas sim em qualquer situação de uso da língua. É interessante notar que, se descolonizar o conhecimento é descer do ponto zero e evidenciar o lugar a partir do qual o conhecimento é produzido, como nos sugere Castro-Gómez (2007), a adoção da expressão made in Brazil nos estudos de ILF faz exatamente isso: demarca uma perspectiva, um ponto de vista, um ponto específico de observação, criando uma corpo-política do conhecimento, uma vez que produz um conhecimento localizado e incorporado.

Contrastando essa corpo-política do conhecimento, importa aqui recuperar e aprofundar algo que já chegamos a mencionar no capítulo sobre a produção científica de ILF, sua gênese europeia e a falta de uma demarcação de lócus de enunciação, apontando para aquilo que o pensamento decolonial chama de distribuição geopolítica do conhecimento. Isso inclui a falta de esclarecimento do lócus epistemológico, como criticam Canagarajah (2013) e O’Regan (2014), não se assumindo enquanto ponto de vista e pretendendo produzir um conhecimento universal, neutro e objetivo acerca do uso de inglês em contexto de língua franca, mas também geográfico, como discutimos a seguir. 


\subsection{Questões ontológicas nos estudos de ILF: que vozes falam mais alto?}

Recuperando a menção a Mignolo (2009) feita ao longo do capítulo, se quisermos desconstruir os pressupostos modernos/coloniais sobre os quais a noção de conhecimento é construída, devemos, para além das questões epistemológicas, voltar nossa atenção para as questões ontológicas, ou seja, é preciso observar quem produz conhecimentos legitimados e validados socialmente e de que parte do mundo eles vêm. Acerca do que pretendemos investigar neste trabalho, significa constatar a quem pertencem as vozes que estudam, produzem e difundem conhecimento sobre ILF e de qual lugar elas provêm.

Para isso, lançamos um breve olhar a um evento importante para a circulação da produção científica sobre ILF, o International Conference of English as a Lingua Franca. Tal evento ocorre anualmente em universidades de diferentes países e conta com a presença de pesquisadores da área também provenientes de diversas partes do mundo. Vejamos, portanto, em que lugares do mundo o evento aconteceu desde sua primeira edição e quem foram os participantes convidados a apresentar (keynote speakers) em algumas dessas edições ao longo dos anos. O site da $13^{\text {a }}$ edição do evento ${ }^{80}$, que ocorreria em 2020 na cidade de Tainan, em Taiwan - mas que foi adiado para 2021 por conta da pandemia do novo coronavírus -, oferece uma lista indicando em que cidade cada edição do evento teve lugar. À essa lista adicionamos o ano e o país onde foi realizada cada edição, conforme indicado a seguir em ordem cronológica:

ELF 1 - 2008 - Helsinque (Finlândia)

ELF 2 - 2009 - Southampton (Reino Unido)

ELF 3 - 2010 - Viena (Áustria)

ELF 4 - 2011 - Hong Kong (China)

ELF 5 - 2012 - Istambul (Turquia)

ELF 6 - 2013 - Roma (Itália)

ELF 7 - 2014 - Atenas (Grécia)

ELF 8 - 2015 - Pequim (China)

ELF 9 - 2016 - Lérida (Espanha)

ELF 10 - 2017 - Helsinque (Finlândia)

ELF 11 - 2018 - Londres (Reino Unido)

ELF 12 - 2019 - Medellín (Colômbia)

Para podermos constatar as informações acima visualmente, representamos esses dados através de um gráfico de mapa, como vemos na Figura 2.

${ }^{80}$ Disponível em <https://tahjou.com/ELF13/>. Acesso em: 19 de outubro de 2020. 
Figura 2 - Países que sediaram o evento International Conference of English as a Lingua

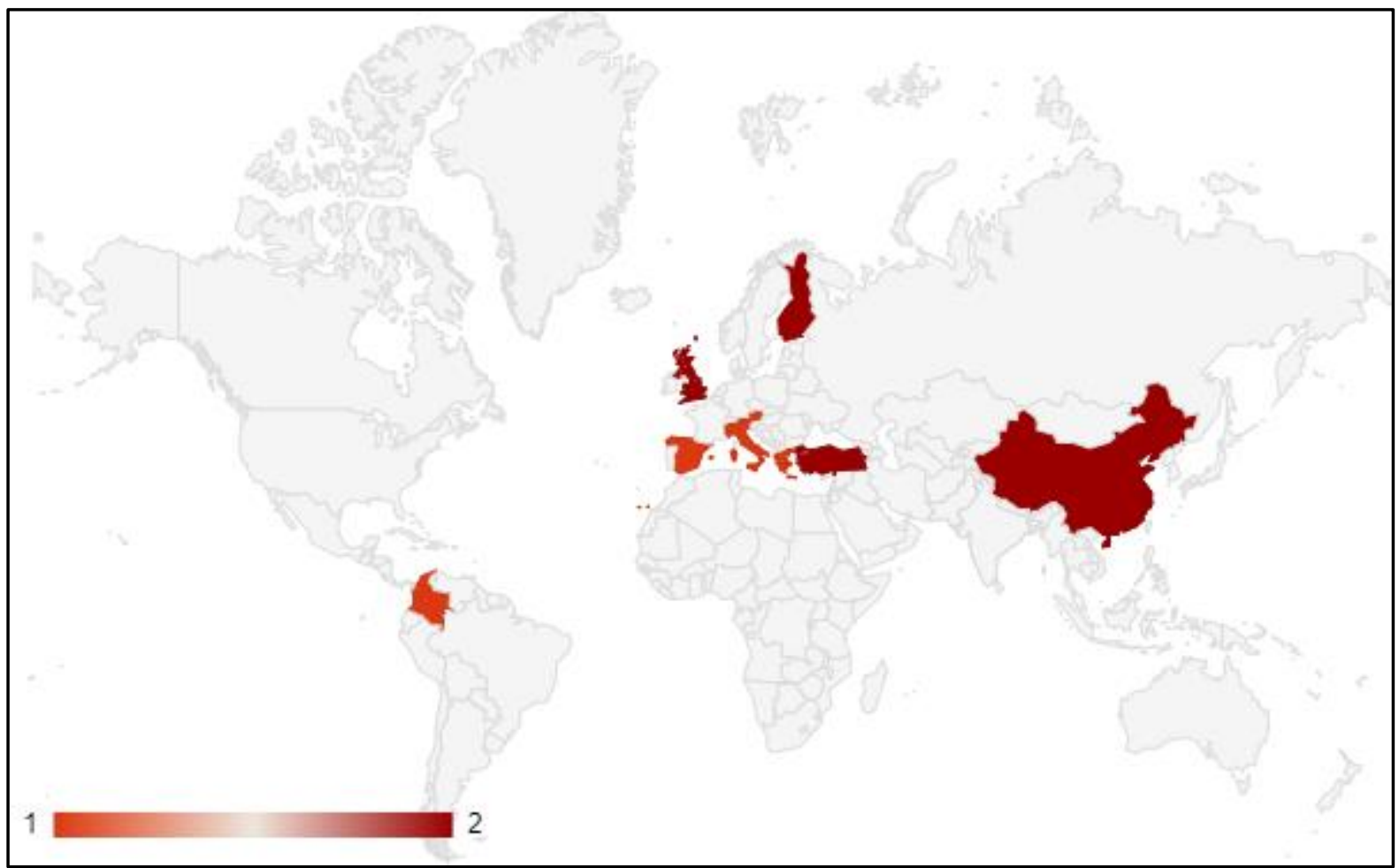

Fonte: elaboração própria a partir de dados obtidos de <https://tahjou.com/ELF13/>

O gráfico acima aponta para uma centralidade europeia na difusão de conhecimento acerca de ILF. Enquanto isso, a América do Sul recebeu o evento apenas uma vez. As considerações acerca dessa constatação serão tecidas a seguir, articuladas à constatação sobre os pesquisadores dessa área de estudos e de qual lugar do mundo eles partem. Para buscar esses dados, nos baseamos em sete das treze edições do evento, tanto as que já ocorreram quanto a prevista para o ano de 2021. Essa seleção se deu por conta das informações disponíveis online sobre o evento, dentre as quais só foram encontrados os sites com informações referentes às edições 7, 8, 9, 10, 11, 12 e 13 da conferência. As informações coletadas incluem os keynote speakers, os convidados para apresentação de colóquios e plenárias. Mais uma vez representamos os dados obtidos através de um mapa, Figura 3 a seguir, a fim de percebermos visualmente a localidade proveniente desses pesquisadores. 
Figura 3 - Local de trabalho dos convidados a keynote speakers e convidados para apresentação de colóquios e plenárias

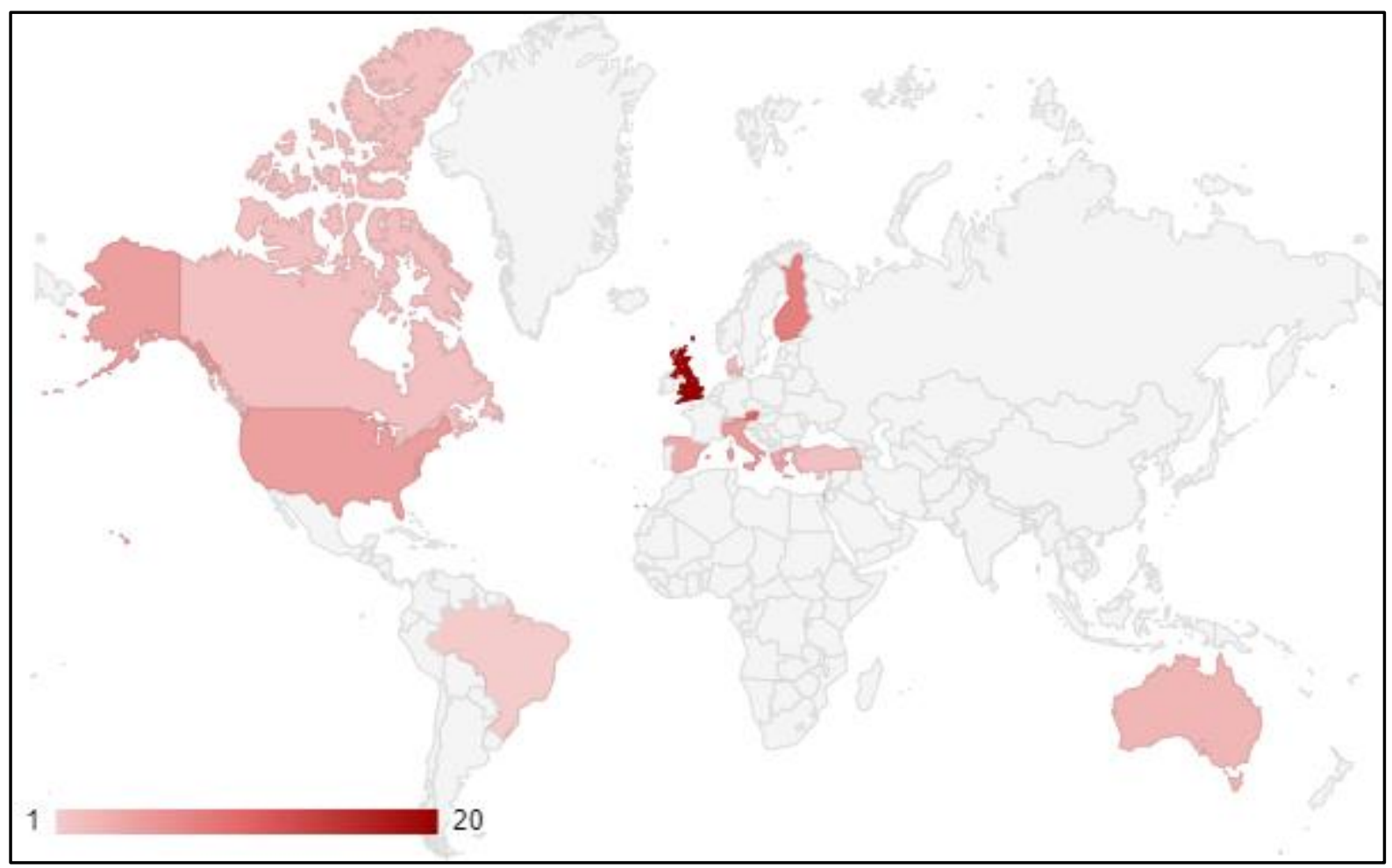

Fonte: elaboração própria

Mais uma vez é possível notar a predominância do Norte Global na produção e divulgação desse conhecimento, principalmente vindo de países europeus como Reino Unido e Áustria, onde surgiram os primeiros estudos de ILF. É interessante observar também que a maior parte dos estudiosos do tema encontra-se no Reino Unido, país que tem como língua oficial o inglês e cujos falantes são comumente vistos como referência no uso e no ensino da língua nos paradigmas tradicionais como ILE.

Através dos dados acima apresentados, inspirados no exercício decolonial de perguntar quem produz e onde é produzido o conhecimento, é possível perceber com mais clareza como a colonialidade está presente nesse campo de estudos, como já havíamos indicado no início do capítulo. As vozes predominantes na difusão do conhecimento produzido sobre ILF continuam a pertencer àqueles provenientes do Norte Global. Entretanto, é importante esclarecermos aqui o que entendemos como Norte Global. Para Sousa Santos (2016), Norte e Sul não são aqui entendidos como conceitos geográficos, mas sim como usos simbólicos dos termos que representam as desigualdades, exclusões e opressões provocadas pelo capitalismo e pelo colonialismo, mas também os movimentos de resistência a esse sistema. Nesse sentido, o Sul também está presente no Norte geográfico, com a existência daqueles que foram historicamente 
marginalizados, excluídos e silenciados. Nesse sentido, Sul e Norte devem ser compreendidos de forma relativa.

Quando falamos da centralidade europeia na produção e na difusão de conhecimento sobre ILF, devemos olhar para a própria Europa também de forma relativa. Sendo assim, enxergamos as Europas dentro da Europa, também com seu Norte e seu Sul, com países como Grécia, Itália, Turquia, Espanha e Portugal ocupando um lugar à margem de países como, por exemplo, Reino Unido. Ao mesmo tempo, ao considerarmos, por exemplo, o Brasil, o que se entende por Norte e Sul se modifica, uma vez que esse país e o conhecimento daqui proveniente são ainda mais marginalizados nessa relação. Com isso, podemos pensar se o conhecimento produzido nessas margens é tão válido quanto o que é produzido no centro, não pelo conhecimento em si, mas pelo valor que se atribui aos corpos que produzem tal conhecimento, no esteio da crítica de Mignolo $(2007,2009)$ quanto à ego-política do conhecimento, de base eurocêntrica, e da necessidade, segundo esse mesmo autor, de nos desprendermos epistemicamente (delinking) das amarras do eurocentrismo partindo de uma geo-corpo-política do conhecimento. Embora tenhamos representado os dados sobre a produção de ILF através de mapas, cabe aqui fazermos uma distinção entre lócus geográfico e lócus epistemológico dos sujeitos que produzem esse conhecimento, complexificando um pouco mais as questões debatidas. Nem sempre aqueles que localizados geograficamente ao Norte partem de um lócus epistemológico hegemônico. Da mesma forma, não necessariamente sujeitos localizados ao Sul assumem um lócus de resistência.

Ao fazermos essas constatações, ecoamos aqui os questionamentos propostos por Duboc; Siqueira (2020, p. 240):

i) O que se sabe sobre os estudos de ILF sendo feitos recentemente fora do cenário acadêmico europeu convencional? ii) Em que medida pesquisadores de ILF de diferentes partes do mundo leem uns aos outros? iii) Em que medida pesquisadores de ILF europeus se envolvem em pesquisas verdadeiramente colaborativas e horizontais como forma de enfrentar o problema da hubris do ponto zero? iv) O quanto da literatura de ILF circulante na academia é representativa das vozes múltiplas e dissidentes representando diferentes loci de enunciação? v) Acadêmicos de ILF do Sul Global têm consciência da matriz colonial de poder na produção do conhecimento? Se sim, em que medida desejam verdadeiramente desprender-se epistêmica e politicamente? vi) Quantos pesquisadores de ILF ainda nomeados como "falantes não-nativos de inglês" já tiveram seu inglês corrigido em processos de revisão por pares de acordo com o inglês padrão? vii) Pesquisadores de ILF do Sul Global reconhecem o valor das brechas e fissuras na tentativa de desmontar mecanismos de filtro e controle de conhecimento em centros acadêmicos convencionais e editoras? viii) Quantas vezes países de fora da Europa sediaram conferências sobre ILF? Quantos pesquisadores do Sul Global já foram convidados como keynote speakers nesses eventos? ix) Em que medida pesquisadores de ILF do Sul Global estão verdadeiramente comprometidos em acabar com sua histórica automarginalização em relação a seus próprios conhecimentos de inglês e produtos de suas 
pesquisas? x) Em que medida pesquisadores de ILF do Sul Global estão engajados em desobedecer, perturbar e transformar o status da pesquisa e da prática em ILF? ${ }^{81}$

Complementamos esses questionamentos com mais algumas perguntas: será que, embora considerado como idioma desterritorializado, os novos usos do inglês por falantes de diferentes partes do mundo só foram legitimados e validados porque tal validação partiu de territórios e vozes do Norte Global? Por que nesse campo de estudos continuam a prevalecer determinadas vozes, provenientes de determinadas localizações geográficas/geopolíticas? As vozes daqueles que fazem uso de ILF, como é o caso de nós brasileiros, estão sendo de fato ouvidas ou ainda são marginalizadas na produção de conhecimento nessa área? Será que a língua, apesar da fluidez e do hibridismo defendidos por essa perspectiva, ainda é um fator que controla e filtra a produção sobre essa própria perspectiva? Se determinadas vozes são mais ouvidas que outras, consequentemente determinados sentidos são mais difundidos que outros. Com isso, será que os modos de conceber ILF mais conhecidos e frequentemente citados por diversos pesquisadores são adequados a todos os contextos em que esse conceito é estudado, partindo até de outras bases epistemológicas? Não pretendemos aqui oferecer respostas a essas perguntas, mas sim provocarmos reflexões sobre como a colonialidade do poder, do saber e do ser se fazem presentes nessas questões.

O caminho percorrido no capítulo demonstra que qualquer tentativa de definir Inglês como Língua Franca deve vir acompanhada pelas ontologias e epistemologias nas quais o conceito se insere. A esse respeito, Duboc (2019, p. 19) afirma que:

Ao que tudo indica, o ILF, a exemplo do pharmakon (DERRIDA, 2005[1985]), é veneno e remédio, a depender de quem o concebe, como o concebe, como se relaciona com os demais agentes do campo e em que bases ontológicas e epistemológicas se ancora.

\footnotetext{
81 i) What is known in relation to ELF studies being recently made outside mainstream European academic sites? ii) To what extent do ELF scholars from different parts around the world read each other? iii) To what extent do mainstream European ELF researchers involve themselves in truly horizontal and collaborative research work as a way to tackle the problem of the zero point hubris? iv) How much of ELF's main literature circulating in the academic realm is representative of multiple and dissent voices ranging different loci of enunciation? $v$ ) Are global south ELF scholars aware of the colonial matrix of power in knowledge production? If so, to what extent do they truly wish to epistemically and politically de-link? vi) How many ELF scholars under the still-ingrained label "non-native speakers of English" have already had their English corrected in peer reviewing processes in accordance to standard English? vii) Do global south ELF researchers truly acknowledge the value of the cracks or fissures in attempting to dismantle gatekeeping mechanisms and knowledge control in mainstream academic centers and publishing houses? viii) How many times have ELF conferences been held in countries other than those located in Europe? How many global south ELF scholars have been invited to be keynote speakers in ELF conferences; ix) To what extent are global south ELF researchers truly committed to disposing of their historical self-marginalization with regards to their own command of English and research products? $x$ ) To what extent are global south ELF researchers engaged in disobeying, disrupting, and transforming the status of ELF research and practice?
} 
De fato, concordamos que o mesmo conceito pode refletir bases ontológicas e epistemológicas distintas. Notamos que os primeiros conceitos de ILF pautavam-se em categorias de uma visão de língua e conhecimento característicos da modernidade e com ecos colonialistas, levando também em conta o fato de esses estudos terem sido provenientes da Europa e desenvolvidos, inclusive, por falantes nativos da língua. Nesses estudos, a língua era vista como um sistema, passível de ser descrita e codificada com contornos claros entre as suas variantes, e era o trabalho empírico que daria legitimidade a esse uso da língua, no qual os critérios de validade de cada forma linguística dependiam não só da inteligibilidade, mas também da frequência e regularidade com que ocorriam. Apesar da diferença terminológica, o conceito de ILF aqui compartilha das mesmas concepções do ILI e do WE.

O mesmo conceito é transformado ao ser compreendido por uma perspectiva de língua que valoriza a produção de significado e considera as relações de poder no seu uso, sendo ainda articulado às ideias de interculturalidade e decolonialidade. A língua se torna uma prática social fluida, dinâmica e é o contexto comunicativo, compreendido de forma ampla, que legitima a validade das formas emergentes. Reafirmamos, portanto, que a base epistemológica de cada conceito é o que deve ser realmente levada em conta quando se defende algum deles, muito mais do que a terminologia escolhida. Para além da epistemologia, cabe também questionarmos as ontologias implicadas nessas discussões e as relações de poder que as permeiam, fazendo com que alguns sentidos sejam mais difundidos, validados e legitimados que outros por conta das vozes que os enunciam e da posição que ocupam nessa relação, fazendo com que a colonialidade do saber seja perpetuada.

A fim de representar esses diferentes sentidos no entorno de ILF, apresentamos na Figura 4 a seguir uma teia de palavras que ajude na visualização dessa complexidade conceitual.

Percebemos, com isso, como o conceito é cercado por uma complexa teia de sentidos, muitas vezes partindo de perspectivas distintas e conflitantes. Desse modo, embora os estudos atuais do campo, como anunciados por Jenkins (2015) na fase 3, apontem para uma visão de língua mais dinâmica, voltada para a produção de sentidos e articulada à noção de translinguagem, ainda encontramos pesquisas que se voltam para ideias de Lingua Franca Core, codificação e variantes, noções intensamente exploradas nas fases 1 e 2 de ILF. Para além desses entendimentos, vimos que há estudos aproximando o fenômeno de ILF a uma perspectiva crítica e decolonial, como é o caso de alguns estudiosos brasileiros, aproximação que vai além das fases descritas por Jenkins (2015). 
Figura 4 - Teia de sentidos no entorno do conceito de ILF

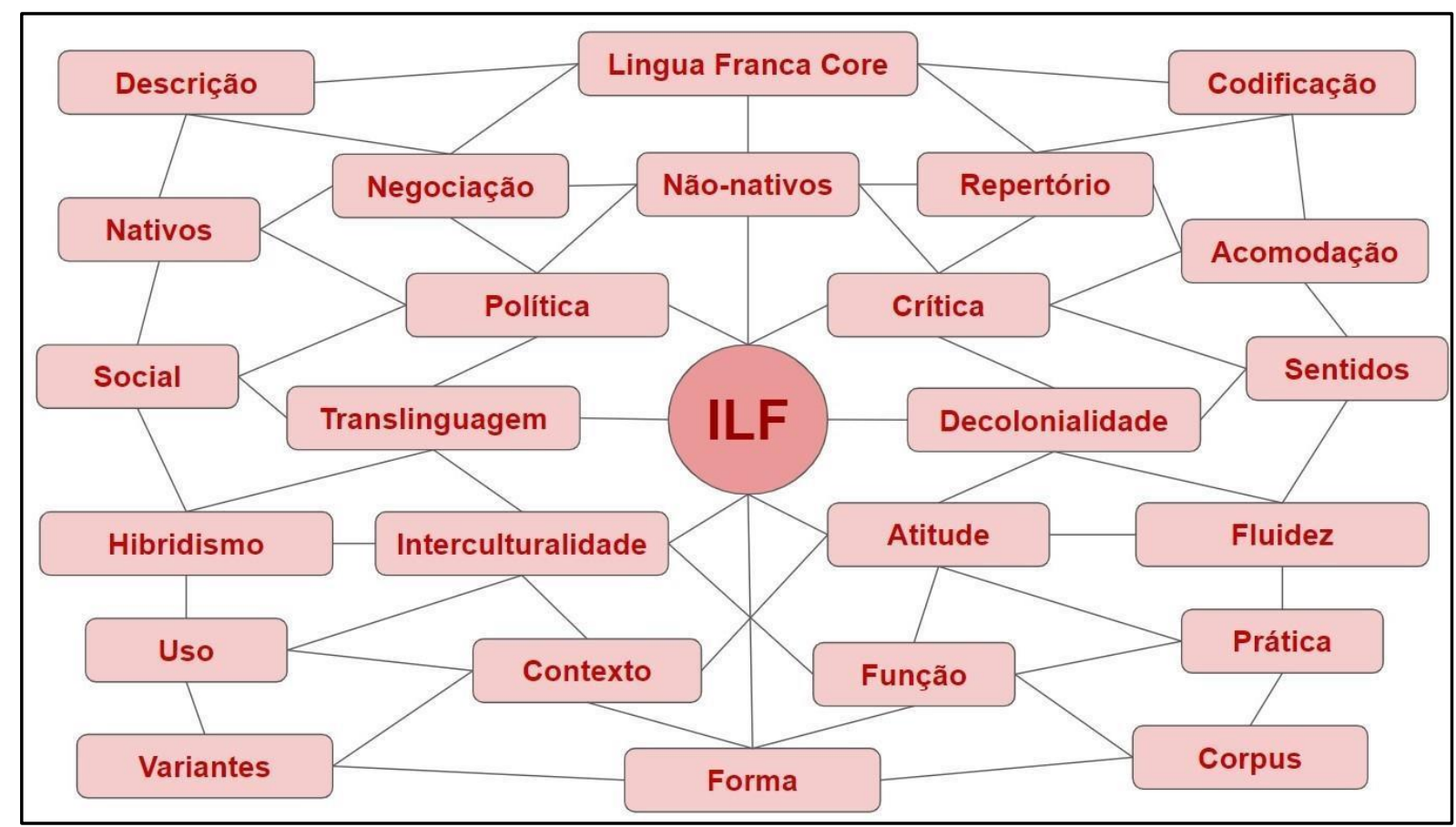

Fonte: elaboração própria

Dada essa complexidade de sentidos, entendemos que qualquer definição de ILF deve ser percebida a partir de quem o define e de que perspectivas de língua, sujeito e conhecimento embasam o conceito. Do mesmo modo, as críticas a ILF também devem ser situadas e necessitam de contextualização em relação a qual sentido de ILF se está criticando. Se não fizermos esse esclarecimento, corremos o risco de cair nas armadilhas da generalização e de descartarmos um conceito pela carga semântica historicamente acumulada que ele carrega. 


\section{CAPÍTULO 3 - ILF EM CAMPO: UM OLHAR ÀS PROPOSTAS CURRICULARES}

Ana Maria is now ten years old, she's learned enough English to translate for her parents but says that her thick accent is still a problem she tries to fix by leaving in her locker when the teacher calls on her to read, she tries to speak "proper" like "proper" has a sound she pushes her tongue down so she doesn't roll her r's but she trips on the flatness of the

syllables that bounce with too much salsa she tries to rattle out the kinks in her speech but her tongue is a stubborn dancer

Denice Frohman

Nos dedicamos agora à análise de três diferentes políticas educacionais brasileiras nas quais o conceito de Inglês como Língua Franca é adotado, a saber, no âmbito nacional, a Base Nacional Comum Curricular - Ensino Fundamental, publicada pelo Ministério da Educação em 2017, e, em esfera municipal, o Direitos de aprendizagem dos ciclos interdisciplinar e autoral, publicado em 2016 pela Secretaria Municipal de Educação de São Paulo, bem como o Currículo da Cidade, publicado em 2017 pela mesma Secretaria.

Partimos de um entendimento de currículo alinhado ao de Silva (2019), que além da questão do conhecimento, considera também a formação das subjetividades. Para o autor, responder qual conhecimento deve ser ensinado é a base de qualquer teoria sobre currículo. Para isso, "as diferentes teorias podem recorrer a discussões sobre a natureza humana, sobre a natureza da aprendizagem ou sobre a natureza do conhecimento, da cultura e da sociedade" (SILVA, 2019, p. 14). Isso implica um processo de seleção, pois cada teoria desenvolve critérios para decidir quais saberes devem fazer parte do currículo, lembrando que essa seleção não ocorre de forma neutra, e sim permeada por relações de poder. Mas o que deve ser ensinado depende da resposta que se dá à pergunta 'que sujeito se pretende formar?', isso porque para determinado tipo de sujeito será necessário um conhecimento específico. O tipo de sujeito a se formar, por sua vez, depende de qual sociedade se espera construir. É possível afirmar, portanto, que aos currículos não basta apenas considerar a dimensão do conhecimento, mas também a das subjetividades formadas através dele. Por isso nossa análise se pauta na compreensão das bases epistemológicas e ontológicas das diferentes propostas curriculares. 
Considerando os múltiplos sentidos carregados pelo acrônimo ILF explorados no capítulo anterior, temos agora como objetivo investigar o sentido desse conceito em cada um dos documentos aqui analisados. Além disso, articulamos esse conceito às práticas pedagógicas sugeridas por essas políticas, a fim de identificar quais os entendimentos de língua, cultura, conhecimento, sujeito e sociedade nelas presentes.

Sustentamos nossa análise com base na noção de campo apresentada por Bourdieu (2004). O autor identifica duas posturas diante das produções culturais, uma internalista e outra externalista. Para a primeira, é suficiente se apropriar dos textos para compreender tais produções. Já para a segunda, o texto deve ser relacionado ao contexto para ser interpretado, inserindo-o no mundo social e econômico. Para o sociólogo francês, nenhuma dessas posturas se mostra suficiente, levando-o a propor a noção de campo como uma alternativa:

Minha hipótese consiste em supor que, entre esses dois pólos, muito distanciados,
entre os quais se supõe, um pouco imprudentemente, que a ligação possa se fazer,
existe um universo intermediário que chamo o campo literário, artístico, jurídico ou
científico, isto é, o universo no qual estão inseridos os agentes e as instituições que
produzem, reproduzem ou difundem a arte, a literatura ou a ciência. Esse universo é
um mundo social como os outros, mas que obedece a leis sociais mais ou menos
específicas (BOURDIEU, 2004, p. 20).

Segundo o sociólogo, embora submetido às leis sociais, o campo usufrui de determinada autonomia em relação a elas, sendo esse grau de autonomia variável, a depender da:

[...] natureza das pressões externas, a forma sob a qual elas se exercem, créditos, ordens, instruções, contratos, e sob quais formas se manifestam as resistências que caracterizam a autonomia, isto é, quais são os mecanismos que o microcosmo aciona para se libertar dessas imposições externas e ter condições de reconhecer apenas suas próprias determinações internas (BOURDIEU, 2004, p. 21).

Atestando essa relativa autonomia do campo, Bourdieu (2004) chama a atenção para a sua capacidade de refração, retraduzindo as pressões externas. Ao mesmo tempo, os problemas exteriores, principalmente políticos, quando refletidos no campo, revelam sua heteronomia.

Dessa forma, entendemos os documentos curriculares como "um campo de forças e um campo de lutas para conservar ou transformar esse campo de forças" (BOURDIEU, 2004, p. 22-23), capaz de refletir e refratar os debates externos a eles. Buscaremos demonstrar, na análise que segue, se as bases epistemológicas e ontológicas de cada documento refletem o sentido de Inglês como Língua Franca neles presente, demonstrando uma coerência, ou se refratam esse sentido, atestando uma contradição interna. Buscamos também identificar as forças, os agentes e as instituições envolvidas no campo curricular que fizeram com que o conceito de ILF orientasse a proposta de ensino da língua inglesa. 


\subsection{Um olhar externalista às propostas curriculares}

Embora uma postura externalista, como afirma Bourdieu (2004), não seja suficiente para compreender uma produção cultural, acreditamos que um olhar ao contexto de produção de cada proposta curricular seja importante para melhor compreendê-las e atingirmos os objetivos de investigação aqui propostos, tentando identificar os agentes envolvidos nesse processo e como o conceito de ILF foi inserido em cada proposta. Embora este trabalho parta da mesma perspectiva teórica que embasa o Direitos de aprendizagem dos ciclos interdisciplinar e autoral, não pretendemos, com essas comparações, indicar uma proposta curricular como a ideal, mas sim evidenciar as diferentes bases epistemológicas e ontológicas em que elas se inserem, problematizando determinados aspectos em cada uma.

Os documentos supracitados foram publicados por diferentes esferas da organização pública e possuem objetivos diferentes. Na esfera municipal, por exemplo, o Direitos de Aprendizagem dos ciclos interdisciplinar e autoral, o primeiro a propor a perspectiva do ILF para o ensino de língua inglesa, foi elaborado localmente a fim de orientar o trabalho desenvolvido na Rede Municipal de São Paulo. Suas primeiras páginas mencionam sua construção a várias mãos, através de reuniões, seminários, grupos de trabalho, debates nas escolas e encontros de formação, resultando no texto publicado em 2016, ainda sob a gestão do prefeito Fernando Haddad e da secretária de educação Nádia Campeão.

Segundo Duboc, Garcia e Rodrigues (2018), em 2014, o Departamento Pedagógico da Secretaria Municipal de Educação de São Paulo (SMESP) buscou reunir professores da rede e consultores externos, que no caso do componente língua inglesa foram as mesmas autoras supracitadas, para desenvolverem um novo programa curricular pautado nas perspectivas de direitos de aprendizagem e descolonização. O envolvimento de professores da própria rede, junto com a assessoria externa, trilhou um caminho diferente do que a elaboração de políticas públicas educacionais costuma seguir, normalmente partindo de órgãos e instituições superiores para então chegar aos contextos locais e aos docentes das instituições escolares, num percurso top-down. Além disso, o processo foi pautado num trabalho colaborativo de escrita que se deu através de reuniões, formações, grupos de estudo, grupos de escrita, conversas em grupos de WhatsApp, reflexões individuais e coletivas e seminários com os assessores externos, professores-autores, outros professores da rede e profissionais escolares, estendendo-se por mais de um ano.

Todo esse processo foi conduzido com o objetivo de captar crenças e práticas sobre o ensino de inglês já existentes na rede que convergissem com uma concepção de língua, ensino e aprendizagem coerente com a intenção de construir um currículo descolonizador e voltado 
para a ideia de direitos de aprendizagem. O conceito de ILF foi então adotado de modo a dialogar com essa perspectiva de currículo, desvencilhando-se de visões eurocêntricas acerca da língua inglesa e compreendendo-a como um direito cultural ao qual todos podem ter acesso. Diante das visões heterogêneas e conflitantes acerca dessas questões, já esperadas em meio a um coletivo tão grande e diverso, buscou-se negociar, discutir e problematizar os sentidos do grupo de modo que se chegasse a uma visão que representasse a identidade dos docentes e o modo de ensinar inglês praticado na rede.

Já no âmbito nacional, adotando também o conceito de ILF para o Componente Curricular Língua Inglesa, a terceira e última versão da Base Nacional Comum Curricular Ensino Fundamental (BNCC) foi apresentada em abril de 2017, sendo instituída pela Resolução $\mathrm{CNE} / \mathrm{CP} \mathrm{n}^{\mathrm{o}} 2$ a partir de dezembro do mesmo ano. Seu texto a apresenta como:

[...] um documento de caráter normativo que define o conjunto orgânico e progressivo de aprendizagens essenciais que todos os alunos devem desenvolver ao longo das etapas e modalidades da Educação Básica, de modo a que tenham assegurados seus direitos de aprendizagem e desenvolvimento (BRASIL, 2017, p. 7, grifo no original).

Seu objetivo, ainda de acordo com o documento, é servir de referência para a formulação de currículos em nível estadual, federal e municipal e nas instituições escolares.

Embora as discussões voltadas para a redação da BNCC e a publicação de sua primeira versão tenham ocorrido apenas em 2015, a ideia de uma base nacional comum para a educação já estava prevista no Artigo 210 da Constituição Federal de 1988 e regulamentada pelo Artigo 26 da Lei de Diretrizes e Bases da Educação Nacional em 1996. Desde então, uma série de documentos reguladores para as diferentes etapas da educação básica foram publicados, incluindo Parâmetros Curriculares Nacionais e Diretrizes Curriculares Nacionais.

Conforme descrito no site do Ministério da Educação, entre 17 e 19 de junho de 2015 ocorreu o I Seminário Interinstitucional para elaboração da BNCC, reunindo assessores e especialistas envolvidos na elaboração da Base. Em 16 de setembro de 2015, a $1^{\text {a }}$ versão do documento é disponibilizada e aberta a debates entre diversos agentes da sociedade.

É importante destacar que o conceito de ILF ainda não está presente nesta versão inicial da BNCC, uma vez que não há um componente voltado exclusivamente para o ensino de língua inglesa, mas sim o Componente Curricular Língua Estrangeira Moderna. Adotando uma perspectiva plurilíngue, o documento não estabelece a obrigatoriedade de ensino de uma língua específica, cabendo a cada comunidade escolar, orientada pelas secretarias de educação locais, escolherem as línguas a serem ofertadas para os alunos a depender de seu contexto.

Para embasar o trabalho com línguas estrangeiras, o componente estabelece que se priorize uma perspectiva discursiva com ênfase na produção de sentidos e no uso da língua por 
meio de gêneros discursivos, em oposição a uma visão tecnicista de língua, na qual prevalece o ensino da gramática e a repetição de frases descontextualizadas.

Os objetivos de aprendizagem do componente são listados e divididos pelos anos escolares do $6^{\circ}$ ano do Ensino Fundamental ao $3^{\circ}$ ano do Ensino Médio, organizados no interior de seis diferentes campos: práticas da vida cotidiana, práticas interculturais, práticas políticocidadãs, práticas investigativas, práticas mediadas pelas tecnologias de informação e comunicação, e práticas do trabalho.

Levando em conta debates, sugestões e pareceres enviados aos organizadores responsáveis, a $2^{\mathrm{a}}$ versão da BNCC é redigida e disponibilizada em 3 de maio de 2016. Assim como a versão inicial, o componente é pautado em uma perspectiva plurilíngue e nomeado como Língua Estrangeira Moderna. Novamente a perspectiva discursiva de uso da língua em práticas sociais é proposta para orientar o ensino, em oposição a uma ideia de língua como sistema. Essa versão acrescenta alguns termos que não estavam presentes na versão anterior, que são educação linguística, interculturalidade, letramentos e práticas sociais, termos estes recuperados de outros documentos reguladores precedentes, como os Parâmetros Curriculares Nacionais (PCN) para Língua Estrangeira Moderna (PCN-LE - terceiro e quarto ciclos do ensino fundamental, 1998; PCNEM, 2000; PCN+, 2002) e as Orientações Curriculares para o Ensino Médio - Linguagens, Códigos e suas Tecnologias (OCEM, 2005). Esses conceitos não são analisados com maior profundidade pelo texto, que apenas esclarece que tais perspectivas implicam:

[...] que a interação por meio de textos nessa língua promova oportunidades de (res)significar a si e ao seu entorno, de refletir sobre modos de atribuir sentidos nas diversas práticas sociais e de desenvolver a percepção e a compreensão sobre a construção de sistemas linguísticos, de discursos e de valores atribuídos aos modos de ser e de dizer (BRASIL, 2016, p. 122).

Em agosto do mesmo ano, a $3^{\mathrm{a}}$ versão da base começa a ser redigida. Importa destacarmos aqui um acontecimento político que consideramos relevante para a análise que segue. O início da redação do que seria a última versão do documento se deu em meio à mudança na ocupação do governo federal. Em 31 de agosto de 2016, Michel Temer, pertencente ao partido Movimento Democrático Brasileiro, assume o cargo de Presidente da República, após o golpe sofrido por Dilma Rousseff, do Partido dos Trabalhadores. Embora pertencentes à mesma chapa eleitoral, os dois governantes e seus partidos possuíam agendas políticas diferentes, o que certamente influenciou nas políticas públicas desenvolvidas no exercício do cargo de cada um deles. 
É apenas na $3^{\text {a }}$ versão do documento, entregue em abril de 2017 ao Conselho Nacional de Educação, homologada e instituída em dezembro do mesmo ano, que vemos o conceito de ILF aparecer no interior do Componente Curricular Língua Inglesa, que passou a ocupar o lugar do Componente Curricular Língua Estrangeira Moderna, instaurando a obrigatoriedade do ensino de inglês a partir do $6^{\circ}$ ano do Ensino Fundamental.

Após essa breve contextualização sobre o processo que culminou na versão final da BNCC, podemos ter a impressão de que, como afirma Duboc $(2019$, p. 16), “o conceito de ILF caiu praticamente de paraquedas no Componente Curricular Língua inglesa da BNCC (BRASIL, 2017)". A ideia de cair de paraquedas, no sentido da expressão, nos remete a algo repentino e inesperado. Mas lembramos que o paraquedas em si é um dispositivo que permite o abrandamento da queda, utilizado de forma planejada e intencional, levando ao sentido oposto da expressão citada. Como vimos, o conceito não estava presente nas duas primeiras versões do documento e, dentre as políticas educacionais nacionais que precederam a Base, nenhuma delas adotava essa perspectiva. Além disso, como afirma a mesma autora, a discussão sobre o tema tanto na formação inicial quanto continuada dos profissionais da língua se mostra ainda incipiente. Levando isso em conta, parece que, de fato, o conceito de ILF caiu de paraquedas no documento, no primeiro sentido da expressão. Quando, porém, rastreamos os agentes, as forças e as lutas que operaram no campo curricular (BOURDIEU, 2004) e que levaram o conceito de ILF a cair no documento, percebemos que essa queda se deu no segundo sentido mencionado, de forma intencional e planejada, para refratar e transformar o caráter normatizador da política em que o conceito se insere, como ficará mais claro na análise que segue. Para recuperar esses rastros, articulamos também à análise sobre a BNCC os pareceres enviados ao Ministério da Educação elaborados por leitores críticos do componente curricular a respeito da $3^{\text {a }}$ versão do documento, antes de sua publicação, além de evidenciar também quem foram os redatores responsáveis pelo componente.

A $3^{\text {a }}$ versão da BNCC em que consta o Componente Curricular Língua Inglesa foi redigida por Adriana Ranelli Weigel, pesquisadora e educadora na área de língua inglesa no CEPEL (Centro de Estudos e Pesquisas no Ensino de Línguas) da Faculdade de Educação da Universidade de São Paulo, e Glaucia d'Olim Marote Ferro, docente aposentada da mesma Instituição. Os leitores críticos, cujos pareceres encontram-se disponíveis no site do Ministério da Educação, são Nina Coutinho e Telma Gimenez (2017) ${ }^{82}$, em nome do British Council; Ana

\footnotetext{
$82 \quad$ Disponível em: < $\quad$ http://basenacionalcomum.mec.gov.br/images/relatoriosanaliticos/Parecer_6_LI_Nina_Coutinho_Telma_Gimenez.pdf $>$. Acesso em: 03 de agosto de 2020.
} 
Paula Martinez Duboc (2016) ${ }^{83}$ e Sandra Tatiana Baumel Durazzo (2017) ${ }^{84}$. Uma busca online também identificou o parecer elaborado por Eduardo Francini $(2017)^{85}$, em nome da embaixada do Reino Unido. Diante de diferentes pareceres elaborados por diferentes agentes do campo educacional brasileiro, cumpre destacar que este trabalho legitima a polissemia e os múltiplos sentidos possíveis nos processos interpretativos do sujeito e julga positivo e saudável a manifestação de diferentes pontos de vista. Assim é que a análise que se segue não visa desmerecer as posições epistemológicas presentes nos pareceres, mas apenas convidar o leitor ao importante exercício genealógico da compreensão do desenho de nossas políticas curriculares.

É interessante observar as impressões que esses pareceristas tiveram sobre a instituição obrigatória do ensino de inglês nos anos finais do Ensino Fundamental trazida pela última versão da base através da substituição do Componente Curricular Língua Estrangeira Moderna pelo Componente Curricular Língua Inglesa. Francini (2017) e Durazzo (2017) não problematizam essa questão, sendo até avaliada positivamente pela segunda parecerista, uma vez que a escolha é justificada pelo status do inglês como língua franca de comunicação internacional. Já Duboc (2016) critica essa substituição, uma vez que a legislação vigente no momento da escrita do parecer garantia a liberdade de escolha da língua estrangeira pela instituição escolar e contradiz a orientação plurilíngue e intercultural que o próprio documento afirma querer promover. Essas diferentes opiniões já nos dão indícios das perspectivas distintas envolvidas na elaboração da proposta curricular e que, de alguma forma, são refletidas no texto final do componente.

No mesmo ano da publicação do documento federal, outro documento é lançado pela SMESP, agora sob gestão do secretário Alexandre Alves Schneider e do prefeito João Dória, para orientar o trabalho na Rede Municipal de São Paulo, o Currículo da Cidade, reelaborado à luz das orientações da BNCC. Assim como o documento anterior, o novo currículo também foi construído de forma coletiva, com a participação de diretores, coordenadores, professores, gestores e técnicos. Além disso, estudantes também foram ouvidos a partir de uma consulta virtual sobre o que e como aprender. O documento foi elaborado por Grupos de Trabalho e contou com revisões de diferentes equipes, até ser finalizado.

\footnotetext{
$83 \quad$ Disponível em: < $\quad$ http://basenacionalcomum.mec.gov.br/images/relatoriosanaliticos/Parecer_6_LI_Ana_Paula_Martinez_Duboc.pdf>. Acesso em: 03 de agosto de 2020.

$84 \quad$ Disponível em: <http://basenacionalcomum.mec.gov.br/images/relatoriosanaliticos/Parecer_6_LI_Sandra_Tatiana_Baumel_Durazzo.pdf>. Acesso em: 03 de agosto de 2020.

85 Disponível em: <https://docplayer.com.br/131375697-Parecer-sobre-o-componente-lingua-inglesa-dodocumento-base-nacional-comum-curricular-bncc-3a-versao.html >. Acesso em: 03 de agosto de 2020.
} 
É interessante mencionar que a assessoria para o componente língua inglesa foi feita pelas mesmas redatoras da BNCC, Adriana Ranelli Weigel e Glaucia d'Olim Marote Ferro, provavelmente em função de suas vastas trajetórias profissionais no campo do ensino de línguas, da notoriedade como autoras da BNCC e do provável desejo por parte da SMESP - à época alinhada politicamente ao governo federal - em desenhar um currículo alinhado aos pressupostos da referida Base.

Apesar de ser uma reconstrução a partir da BNCC, o texto expõe a intenção de dar continuidade aos trabalhos na rede de gestões anteriores. De fato, notamos que muitos aspectos do documento de 2016 são aqui recuperados e, além disso, muitos dos profissionais da rede municipal envolvidos na construção do documento da gestão anterior permaneceram na construção desse novo documento, embora a forma de organização da prática pedagógica e as orientações da BNCC tenham trazido modificações e implicações significativas, conforme sugere a análise a seguir.

\subsection{Mas de qual ILF falamos?}

Uma vez que exploramos a multiplicidade de sentidos presentes no acrônimo ILF no capítulo anterior, cabe aqui definir qual sentido do conceito é adotado pelos documentos curriculares sob análise.

Para o Direitos de Aprendizagem, na esfera municipal, ILF é entendido como "a língua comum usada em situações de interação entre falantes advindos de diferentes comunidades discursivas e portadores de repertórios linguístico-culturais variados” (SÃO PAULO, 2016, p. 23). Além de ser uma língua de contato, conceber o inglês em sua função de língua franca implica, para o documento, considerar o aspecto político e cultural do idioma na sociedade globalizada, uma vez que se trata de uma língua vinculada historicamente à dominação por meio do imperialismo britânico e estadunidense. Diante dos novos usos globais do idioma por falantes não-nativos, o inglês se desvincula das culturas e padrões linguísticos estadunidenses ou britânicos para ser apropriado e modificado por aqueles que dele fazem uso. Nesse sentido, torna-se:

[...] uma língua que possibilita a produção, colaboração e distribuição do conhecimento entre sujeitos pertencentes a comunidades linguístico-culturais distintas, e que serve para o agenciamento crítico nas novas mobilizações sociais que vem ocorrendo em todo o globo. Assim é que, para além de estudos estritamente estruturais ou funcionais, o ensino de inglês como língua estrangeira na contemporaneidade expande seu escopo, assumindo um importante desafio: o ensino de suas especificidades no que tange a aspectos linguístico-discursivos concomitantemente a formação ética e responsável dos educandos e educandas para 
que estes possam melhor responder as demandas de uma sociedade plurilíngue e transcultural (SÃO PAULO, 2016, p. 11, ênfase no original).

O conceito é apresentado de forma semelhante no documento federal da BNCC, afirmando a função social e política assumida por essa perspectiva. O texto afirma que "a língua inglesa não é mais aquela do 'estrangeiro', oriundo de países tidos como hegemônicos, cujos falantes servem de modelo a ser seguido, nem tampouco trata-se de uma variante da língua inglesa” (BRASIL, 2017, p. 239). Já nesse trecho, é possível identificar uma oposição ao paradigma do ILE, mas também um entendimento de ILF que rejeita a ideia de uma única variante construída a partir dos usos criativos dos falantes, como se pretendia no início dos estudos nessa área. Em seguida, esclarece-se qual o sentido impresso ao termo:

Nessa perspectiva, são acolhidos e legitimados os usos que dela fazem falantes
espalhados no mundo inteiro, com diferentes repertórios linguísticos e culturais, o que
possibilita, por exemplo, questionar a visão de que o único inglês "correto" - e a ser
ensinado - é aquele falado por estadunidenses ou britânicos. Mais ainda, o tratamento
do inglês como língua franca o desvincula da noção de pertencimento a um
determinado território e, consequentemente, a culturas típicas de comunidades
específicas, legitimando os usos da língua inglesa em seus contextos locais (BRASIL,
2017, p. 239,240 ).

Esse entendimento dialoga com aquele apresentado no Direitos de Aprendizagem, uma vez que o compreende enquanto um uso da língua feito por falantes de repertórios linguísticoculturais variados e como um idioma desterritorializado. Tal perspectiva é também definida pelos seus "usos híbridos, marcada pela fluidez e que se abre para a invenção de novas formas de dizer, impulsionada por falantes pluri/multilíngues e suas características multiculturais" (BRASIL, 2017, p. 240). Adotar esse entendimento implica uma educação linguística que priorize a inteligibilidade a despeito de aspectos como “"correção', 'precisão' e 'proficiência' linguística” (BRASIL, 2017, p. 240), voltando-se para a interculturalidade, para o reconhecimento e o respeito às diferenças, e para como elas são produzidas, exigindo do professor uma atitude de acolhimento e legitimação dessas diferenças (BRASIL, 2017).

Ainda segundo o documento, a concepção de língua que embasa o entendimento de ILF é como construção social, cabendo ao sujeito interpretar, reinventar e criar sentidos de modo situado.

Cabe aqui salientar uma diferença entre o texto dos dois documentos. O currículo municipal é marcado pelas referências bibliográficas que embasam seus conceitos norteadores, tais como Jenkins (2006a, 2009, 2015), Siqueira (2011, 2013), Jordão (2009, 2010, 2014), Rajagopalan (2010, 2011), Duboc (2014, 2015), Pennycook (1994, 2001, 2013), Canagarajah (1999, 2007, 2011), Canagarajah e Wurr (2011) Bakhtin e Volochinov (2004 [1929]), dentre outros. Já o documento nacional, em contrapartida, é escrito sem apresentar referências 
bibliográficas. Por ser algo que não se restringe apenas ao Componente Curricular Língua Inglesa, mas a todos da BNCC, presumimos que essa tenha sido uma orientação dada aos redatores para a formulação do texto. A diferença constatada entre os dois documentos produz efeitos de sentido que interpretamos novamente à luz do pensamento decolonial. $\mathrm{O}$ fato de o primeiro documento marcar suas referências ajuda a esclarecer quais pontos de vista o documento assume, o que Castro-Gómez e Grosfoguel (2007) exemplificam como ponto 1, ponto 2, ponto $\mathrm{n}$, etc., e, consequentemente, assume-se enquanto ponto de vista. $\mathrm{O}$ segundo documento, por sua vez, por não esclarecer seu ponto de vista, parece querer partir do ponto zero (GROSFOGUEL, 2007), de um ponto de vista acima de todos os outros, pretendendo-se neutro, objetivo e universal. Tal interpretação parece coerente com a própria natureza da BNCC, cujo objetivo é ser justamente o ponto de partida, o ponto zero para toda a educação nacional.

Embora esse apagamento ocorra, ainda assim é possível identificar, no texto apresentado no Componente, as vozes provenientes de autores do campo de estudos de ILF. Ao mencionar a desvinculação do inglês de um determinado território, ouvimos a voz de Siqueira (2011) falando sobre um idioma desterritorializado. Ao negar um entendimento de ILF como uma variante, Jordão e Marques (2018), Gimenez, Calvo e El Kadri (2015) e Siqueira (2015) são recuperados. Ao articular ILF ao conceito de interculturalidade, ouvimos Gimenez, Calvo e El Kadri (2015) Siqueira (2015, 2018). Ao trazer a noção de atitude de acolher e legitimar esses usos, lembramos da noção de atitude curricular de Duboc (2017).

Além disso, ao compararmos o texto apresentado na BNCC com os pareceres enviados ao Ministério da Educação sobre o componente em questão, é possível notar qual perspectiva entre os leitores críticos prevaleceu na redação final. Francini (2017) propõe a adoção da perspectiva do Inglês como Língua Adicional, de modo a valorizar outras línguas que os alunos possam conhecer, através de uma perspectiva plurilíngue e intercultural, considerando o inglês como uma língua aditiva. O termo língua franca, para o parecerista, aparece enquanto status da língua inglesa em meio aos processos globalizantes, e não enquanto perspectiva para o ensino da língua. Durazzo (2017) não explicita uma sugestão nesse sentido, apenas afirma que o caráter internacional da língua deve ser aprofundado, uma vez que a ideia de determinadas variantes terem mais prestígio que outras ainda persiste no ensino de língua inglesa, o que sugere que a parecerista concorda com a proposta de ILF já adotada pelo documento. Sugere, para isso, o uso de materiais autênticos provenientes de origens variadas, incluindo produções em inglês com falantes de diversas primeiras línguas, sugerindo um entendimento que considera que a exposição a diferentes variantes equivale a ensinar inglês na perspetiva de ILF. Coutinho e Gimenez (2017) concordam com a adoção de ILF, mas criticam a indefinição do conceito 
apresentado no texto, uma vez que primeiro se apresenta uma visão do idioma como desterritorializado por seu caráter de comunicação internacional, mas os objetivos de aprendizagem apontam para um entendimento que o vincula a territórios onde ele é nativo ou nativizado, contradizendo a proposta inicial, e destacam o papel do ensino do idioma como forma de refletir sobre língua, poder, identidade e interculturalidade. Duboc (2016) também sugere que se esclareça a escolha terminológica, contextualizando os diversos acrônimos que circulam nos estudos do inglês e ressalta a importância de se considerar a função social e política no aprendizado da língua. Notamos, com isso, diferentes compreensões sobre ILF e sobre as implicações que a sua adoção traz para o currículo.

Novamente na esfera municipal, o Currículo da Cidade, por sua vez, recorre tanto ao Direitos de Aprendizagem como à BNCC para apresentar essas concepções. ILF é definido através da mesma citação do Direitos de Aprendizagem destacada anteriormente (SÃO PAULO, 2016, p. 11), com o acréscimo de alguns elementos do texto introdutório da BNCC referente a esse componente curricular, conforme segue (SÃO PAULO, 2017, p. 69):

Essa perspectiva permite questionar a visão de que o único inglês correto - e a ser
ensinado - é aquele falado por estadunidenses ou britânicos, por exemplo. Em função
disso, o tratamento do inglês como língua franca o desvincula da noção de
pertencimento a um determinado território e, consequentemente, a culturas típicas de
comunidades específicas. Esse entendimento favorece uma educação linguística
voltada para a interculturalidade, isto é, para o reconhecimento das (e o respeito às)
diferenças e para a compreensão de como elas são produzidas (BRASIL, 2017).

A concepção de língua como prática e construção social também é recuperada do documento de 2016 (SÃO PAULO, 2016, p. 22), segundo a qual os sentidos são construídos no contexto discursivo, por isso possibilita que sejam múltiplos. “'Sob essa perspectiva, o sujeito não mais 'codifica' ou 'identifica' o que lhe foi comunicado com base em modelos previamente definidos, mas 'significa', 'interpreta', 'reinventa' os sentidos de modo situado'” (SÃO PAULO, 2017, p. 68).

Consideramos que os três documentos partem, teoricamente, de uma concepção de língua como prática e construção social e parecem convergir no sentido que imprimem ao conceito de ILF, sentido que, por sua vez, dialoga com os entendimentos mais recentes e locais do termo, principalmente aqueles produzidos por pesquisadores nacionais e explorados no segundo capítulo deste trabalho, como Jordão e Marques (2018), Duboc (2018) e Siqueira (2015, 2018), destacando aspectos como a desterritorialização do idioma, a produção de sentidos no uso da língua, o papel político e social da língua inglesa no currículo e o ensino crítico do idioma. 


\title{
3.3 E de qual interculturalidade falamos?
}

Ao proporem o conceito de ILF, os três documentos o articulam à noção de interculturalidade, que, como vimos no capítulo anterior, é defendida por autores como Gimenez, Calvo e El Kadri (2015) e Siqueira (2018). Prosseguiremos nossa análise nos detendo a esse aspecto. Para isso, vejamos primeiramente como o conceito é compreendido por alguns teóricos.

Walsh (2012) afirma que esse conceito hoje está presente em políticas públicas educacionais e constitucionais na América Latina, mas alerta que, embora possa parecer que essa inserção seja fruto das demandas por reconhecimento, direitos e transformação social, pode também estar a serviço das exigências globais do mercado e do capital. Dessa forma, a interculturalidade pode simplesmente servir ao sistema dominante ou pode ser concebida como projeto de transformação e decolonialidade. Sendo assim, não é o uso do conceito que garante o seu sentido, mas sim a apropriação que é feita dele.

A autora então distingue três perspectivas diante da interculturalidade. A primeira delas é a interculturalidade relacional, que diz respeito à relação, ao contato e ao intercâmbio entre culturas, correndo o risco de minimizar os conflitos decorrentes do contato entre as diferenças e as relações de poder que acarretam a desigualdade. As estruturas sociais, políticas, econômicas e epistêmicas que promovem essa desigualdade permanecem inalteradas. Já a interculturalidade funcional pretende incluir a diversidade e a diferença na estrutura social já estabelecida. Nesse caso, o conceito é apropriado por políticas estatais neoliberais para servir a lógica mercadológica, baseando-se nos pressupostos da superioridade cultural e da hospitalidade condescendente, buscando promover o diálogo, a tolerância e a convivência, sem questionar as assimetrias e as desigualdades. Segundo Walsh (MIGNOLO; WALSH, 2018, p. $58)$ :

\begin{abstract}
Através da inclusão individual, a fachada do diálogo e o discurso da cidadania, a interculturalidade funcional constitui um modo mais complexo de dominação que captura, coopta, pacifica, desmobiliza e divide movimentos, coletivos e líderes, impele o individualismo, a complacência e a indiferença; e reforça a convolução estrutural e crescentemente composta do capitalismo e da colonialidade. ${ }^{86}$
\end{abstract}

A inclusão aqui serve para gerir a diversidade de modo que ela não se torne uma fonte de ameaça à ordem estabelecida. A interculturalidade funcional parte das mesmas bases do multiculturalismo, entendido como "o reconhecimento da diversidade cultural por governantes,

\footnotetext{
${ }^{86}$ Through individual inclusion, the facade of dialogue, and the discourse of citizenship, functional interculturality constitutes a more complex mode of domination that captures, co-opts, pacifies, demobilizes and divides movements, collectives, and leaders; impels individualism, complacency, and indifference; and shrouds the structural and increasingly compound convolution of capitalism and coloniality.
} 
estados, instituições multilaterais e organizações internacionais não-governamentais, efetuadas através de políticas de inclusão que, mais do que frequentemente, está ligada aos interesses da ordem dominante" ${ }^{87}$ (MIGNOLO; WALSH, 2018, p. 57). Para integrar a lógica neoliberal dominante, o projeto multicultural acaba servindo para amenizar os conflitos decorrentes das diferenças culturais a fim de inserir as minorias marginalizadas na ordem global capitalista, reproduzindo as relações coloniais.

No interior dos currículos, essa perspectiva reflete o que Silva (2019) chama de multiculturalismo liberal ou humanista, que parte da premissa de que apesar das diferenças superficiais expressas pela diversidade cultural, todos pertencemos a uma mesma humanidade, como se fôssemos dotados de uma essência. Segundo o autor, "esse tipo de multiculturalismo apela para o respeito, a tolerância e a convivência pacífica entre as diferentes culturas. Deve-se tolerar e respeitar a diferença porque sob a aparente diferença há uma mesma humanidade" (SILVA, 2019, p. 86). Segundo essa perspectiva, o currículo se baseia "nas ideias de tolerância, respeito e convivência harmoniosa entre as culturas" (SILVA, 2019, p. 88). Ele ainda ressalta as implicações presentes nas noções de tolerância e respeito: tolerar implica uma certa superioridade por parte de quem tolera; respeitar, por sua vez, acarreta "um certo essencialismo cultural, pelo qual as diferenças culturais são vistas como fixas, como já definitivamente estabelecidas, restando apenas 'respeitá-las"” (SILVA, 2019, p. 88). Candau (2008) menciona uma perspectiva semelhante, o que chama de multiculturalismo assimilacionista, cujo objetivo é fazer com que os grupos marginalizados e discriminados se integrem na sociedade e assimilem os valores e saberes da cultura hegemônica. O caráter monocultural da educação, no que se refere aos conteúdos do currículo e sua dinâmica, não é questionado. Em nome de um projeto de construção de uma cultura comum, “dialetos, saberes, línguas, crenças, valores 'diferentes', pertencentes aos grupos subordinados, considerados inferiores explícita ou implicitamente" (CANDAU, 2008, p. 50), são excluídos e deslegitimados.

Por fim, Walsh (2012) defende o que ela chama de interculturalidade crítica, que vai além de uma inter-relação ou diálogo entre culturas, questionando a estrutura colonial e racial herdada que serve ao capitalismo. Nesse sentido, é vista como uma ferramenta para a práxis da decolonialidade, cujo objetivo é a construção de uma sociedade radicalmente diferente através da transformação das estruturas econômicas, sociais, políticas e culturais, abalando um projeto fundado em uma base capitalista, moderna e colonial. Pretende tornar visível o legado apagado

87 [...] the recognition of cultural diversity by governments, states, multilateral institutions, and international nongovernmental organizations, effectuated through a politics of inclusion that, more often than not, is tied to the interests of the dominant order. 
pela diferença colonial. Citando uma ativista equatoriana, ela define o conceito como "simplesmente a possibilidade da vida, de um projeto alternativo de vida, que questiona profundamente a lógica irracional instrumental do capitalismo nestes tempos"88 (MIGNOLO; WALSH, 2018, p. 57).

Nesse sentido, interculturalidade não é um projeto pronto e estável, mas sim um processo de constante transformação e reconceituação de estruturas e instituições, colocando em diálogo, ainda de forma conflituosa, diversas formas de saber, pensar, ser e viver. As diferenças, portanto, não são apagadas, mas permanente e ativamente negociadas (MIGNOLO; WALSH, 2018).

No que diz respeito ao campo curricular, tal entendimento de interculturalidade dialoga com o que Silva (2019) chama de uma perspectiva multicultural crítica e política, segundo a qual "as diferenças culturais não podem ser concebidas separadamente de relações de poder" (SILVA, 2019, p. 86). Um currículo multicultural crítico se preocupa com "os processos pelos quais as diferenças são produzidas através de relações de assimetria e desigualdade. [Nessa perspectiva], a diferença, mais do que tolerada ou respeitada, é colocada permanentemente em questão" (SILVA, 2019, p. 88), pois é constantemente produzida e reproduzida através das relações de poder. Segundo o autor, entende-se que a diferença não é natural, mas sim produzida linguística e discursivamente, e é relacional, pois só se pode ser diferente em relação ao que é não-diferente. Se cada termo dessa relação adquire uma conotação positiva ou negativa é porque há também relações de poder.

Para Silva (2019), há uma diferença entre um currículo folclórico, que apenas adiciona informações superficiais sobre outras culturas, celebrando a diferença e a diversidade, e um currículo que lida com essas questões de forma crítica, histórica e política, questionando a diferença e a diversidade, trazendo as seguintes problematizações:

Quais são os mecanismos de construção das identidades nacionais, raciais, étnicas?
Como a construção da identidade e da diferença está vinculada a relações de poder?
Como a identidade dominante tornou-se a referência invisível através da qual se
constroem as outras identidades como subordinadas? Quais são os mecanismos
institucionais responsáveis pela manutenção da posiçãa subordinada de certos grupos
étnicos e raciais? (SILVA, 2019, p. 102).

Com essas concepções em mente, vejamos agora como cada proposta curricular define o conceito de interculturalidade.

\footnotetext{
88 [...] simply the possibility of life, of an alternative life-project that profoundly questions the instrumental irrational logic of capitalism in these times'.
} 
No nível municipal, o Direitos de Aprendizagem optou na verdade pelo uso de inter/transculturalidade, como forma de abarcar os sentidos que ambos os prefixos trazem. Segundo o documento (SÃO PAULO, 2016, p. 25):

O uso desses novos prefixos marca a fluidez e o hibridismo da pós-modernidade: do prefixo inter-, destacam-se as relações de troca entre sujeitos, povos e culturas (Candau, 2008); quanto ao prefixo trans-, procura-se destacar a ideia da mobilidade, da transitoriedade, do estar em trânsito constantemente quando significamos o outro em uma perspectiva que prevê o "plural entre si" e também o "plural em nós mesmos" (WELSCH, 1999).

A escolha se dá como alternativa ao termo multiculturalismo, uma vez que este parece não abarcar a complexidade da noção de cultura, dando "margem para a mera constatação da existência de múltiplas culturas, como se fossem unidades homogêneas e autossuficientes (Bhabha, 1998), apenas 'plurais entre si'” (SÃO PAULO, 2016, p. 25).

Na esfera nacional, a BNCC, ao articular a perspectiva do ILF com a interculturalidade, entende esta noção como "o reconhecimento das (e o respeito às) diferenças, e para a compreensão de como elas são produzidas nas diversas práticas sociais de linguagem, o que favorece a reflexão crítica sobre diferentes modos de ver e de analisar o mundo, o(s) outro(s) e a si mesmo" (BRASIL, 2017, p. 240).

Novamente no âmbito municipal, o Currículo da Cidade apenas recorre aos documentos anteriores para explicar essa noção, citando o mesmo excerto da BNCC (BRASIL, 2017, p. 240) e trazendo o Direitos de Aprendizagem no que se refere à "presença cada vez mais notória dos processos de inter/trans/culturalidade devido a fluxos migratórios cada vez mais intensos, conferindo à Rede uma nova faceta multicultural e plurilíngue" (SÃO PAULO, 2017, p. 6970).

Como mencionado anteriormente, não é o uso de um conceito e o modo como ele é definido que garante o seu sentido, mas sim a apropriação que é feita dele. Com essa afirmação em mente e à luz dos sentidos atribuídos ao conceito de interculturalidade, cabe a nós entender, para além do modo como cada currículo a define, de que maneira esse conceito é por eles apropriado e em quais bases epistemológicas e ontológicas ele é inserido. Para isso, ao nos debruçarmos sobre o conceito de currículo, sobre a organização de cada documento e como eles propõem a prática pedagógica, buscaremos indícios que nos permitam entrever se a interculturalidade é tratada em sua potencialidade crítica e transformadora ou apenas como interculturalidade funcional, aproximando-a da perspectiva do multiculturalismo liberal. Um desses indícios é como os currículos tratam a questão da diferença e da diversidade e, no caso da BNCC e do Currículo da Cidade, o que se sugere no Eixo Dimensão Intercultural, uma vez 
que nesses documentos o trabalho com a língua é proposto de forma fragmentada, como veremos a seguir.

\subsection{Uma leitura between the lines}

Como um dos aspectos que observaremos nos documentos é a questão da diferença, cabe aqui trazermos a relação comentada por Candau (2008) entre a igualdade e a diferença. Segundo ela, a modernidade enfatizou a igualdade entre os seres humanos, em detrimento das diferenças raciais, nacionais, sexuais, dentre outras, enquanto hoje a ênfase recai sobre a diferença e as questões identitárias. Para a autora, não se trata de afirmar ou negar completamente um dos pólos, mas sim de articulá-los, trabalhando a igualdade na diferença. Para isso, ela menciona Sousa Santos (2006, p. 462 apud CANDAU, 2006, p. 49), para quem “"temos o direito a ser iguais, sempre que a diferença nos inferioriza; temos o direito de ser diferentes sempre que a igualdade nos descaracteriza"'. Com isso em mente, voltamo-nos agora à análise de qual concepção de currículo cada documento adota e de como eles se estruturam, como se articulam ao conceito de ILF e de interculturalidade neles presente, observando o modo como entendem essa relação entre igualdade e diferença.

O comprometimento com um currículo descolonizador é mencionado inúmeras vezes ao longo do texto do Direitos de Aprendizagem, como forma de romper com o viés eurocêntrico predominante no ensino de línguas estrangeiras, com visões de mundo hegemônicas e verdades únicas e universais. Articulado ao trabalho com a língua inglesa, o currículo é concebido como um:

'conjunto de experiências educativas as quais educandos e educandas estão expostos
no ambiente escolar' (SÃO PAULO, 2015, p. 37. Diálogos Interdisciplinares a
Caminho da Autoria). Essas experiências educativas são situadas em determinado
momento histórico, social e econômico que também as reflete - reproduzindo valores
e comportamentos vigentes nas relações construídas dentro e fora da escola - e as
refrata - deslocando tais valores e comportamentos e apontando para novas
potencialidades de sentido. O inglês está no currículo, está na escola, está na
comunidade. Portanto, é direito dos estudantes se perceberem cidadãos de um mundo
plurilíngue e inter/transcultural que se constitui na diferença, e ter suas vivências e
experiências linguísticas e culturais valorizadas ao longo de seu percurso de
aprendizagem de inglês (SÃO PAULO, 2016, p. 32).

Esse entendimento, associado à intenção de um currículo descolonizador, aponta para uma valorização da diferença no interior do currículo e da escola, aproximando-se da perspectiva multicultural crítica comentada por Silva (2019) e da orientação sociológica/intercultural mencionada por Libâneo (2016, p. 42), que defende "a formação por meio de experiências socioculturais vividas em situações educativas (por exemplo, práticas de compartilhamento de diferentes valores e de solidariedade com base em experiências cotidianas 
e na aceitação da diversidade social e cultural)". O documento prossegue com a exposição daquilo que seria oferecido através dessas experiências educativas em inglês, que seria o "direito de acessar, conhecer e refletir sobre o conjunto de patrimônios culturais, materiais e imateriais, produzidos e difundidos em língua inglesa por comunidades discursivas de repertórios linguístico-culturais variados” (SÃO PAULO, 2016, p. 32-33). Tal direito se alinha à concepção de cultura que Forquin (1993, p. 12) reconhece como sendo responsabilidade da escola transmitir, definida como "um patrimônio de conhecimentos e de competências, de instituições, de valores e de símbolos, constituído ao longo de gerações e característico de uma comunidade humana particular". A ideia de patrimônios construídos por comunidades se repete, embora o autor se refira a uma "comunidade humana particular" e o documento enfatize a variedade de comunidades linguístico-culturais.

Quanto às orientações metodológicas, o documento não tem a pretensão de prescrever um método único de trabalho, como muito se buscou no campo do ensino de línguas estrangeiras, dada a complexidade das relações no mundo contemporâneo e as especificidades de cada contexto de ensino. Em consonância com o direito à diferença no qual se baseia o projeto educativo nacional e municipal, em vez de um método ideal universalizante, propõe-se pedagogias situadas, que considerem todos os envolvidos na experiência educativa tecendo relações entre o global e o local, o externo e o interno.

A intenção de produzir um currículo descolonizador, articulada à defesa de pedagogias situadas, considera essencial que se vá além de materiais que rompam com visões eurocêntricas usualmente disseminadas por livros didáticos elaborados por editoras de países centrais. Para isso, o professor se torna produtor de seus próprios materiais, buscando recursos "nas mídias impressas que porventura tenha acesso e, principalmente, nas inúmeras mídias digitais hoje disponíveis (websites, blogs, jornais e revistas online, ebooks ou livros digitais, comunidades de prática online, redes sociais, dentre outros)" (SÃO PAULO, 2016, p. 45-46).

No que diz respeito ao que deve ser ensinado, não é apresentada uma lista de conteúdos que devem ser trabalhados em determinado período de tempo. Em vez disso, vivências e experiências em língua inglesa são propostas através da representação visual de uma árvore, como ilustrado na Figura 5 a seguir, na qual se encontram, em posição central, as ações de brincar, investigar e intervir, relacionadas aos três ciclos que organizam os 9 anos do Ensino Fundamental (Alfabetização, Interdisciplinar e Autoral) e a ênfase em uma ação que cada ciclo pretender dar. 


\section{Figura 5 - Eixos estruturantes do Currículo de Língua Inglesa}

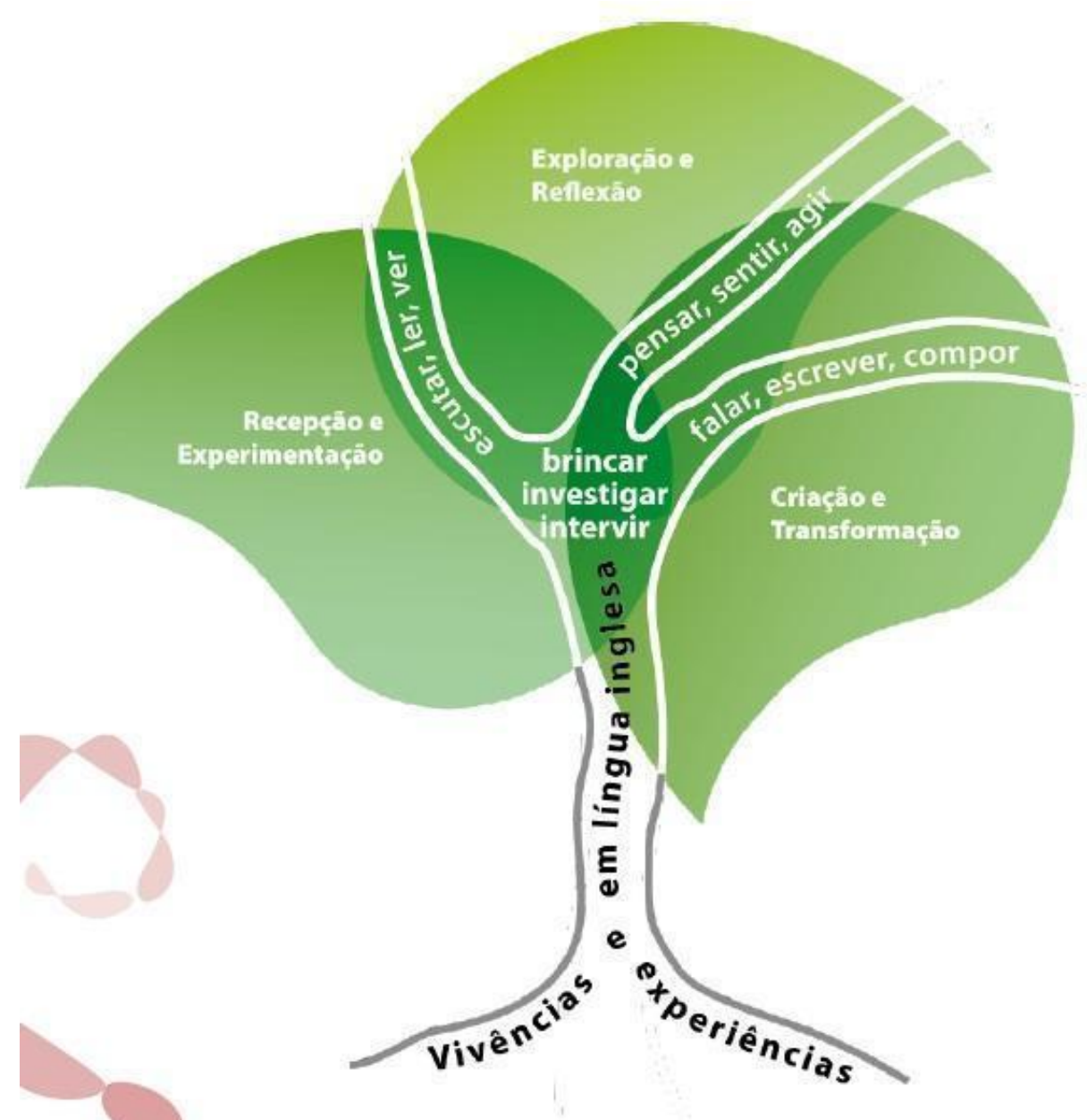

Fonte: São Paulo (2016, p. 34)

A integração dos eixos Recepção e Experimentação, Exploração e Reflexão, e Criação e Transformação pretende dar "materialidade ao nosso compromisso com a problematização, a crítica e o agenciamento, ideias preciosas ao conceito de Inglês como Língua Franca (ILF), possibilitando, assim, criar condições que garantam, a nossos educandos e educandas, os direitos de aprendizagem de Língua Inglesa" (SÃO PAULO, 2016, p. 38). Tais direitos são, também, representados visualmente no documento, conforme vemos na Figura 6 a seguir.

Articulado ao conceito de Inglês como Língua Franca e aos eixos estruturantes que embasam os direitos de aprendizagem em língua inglesa, o documento ressalta seu compromisso com a diferença e a diversidade presente na cidade e na própria sala de aula, lembrando que nela habitam "brasileiros, nortistas, sulistas, nordestinos, nigerianos, bolivianos, coreanos, chineses, entre outros" (SÃO PAULO, 2016, p. 38), a fim de acolher e promover o diálogo entre as diversas culturas. 
Figura 6 - Direitos de Aprendizagem de Língua Inglesa

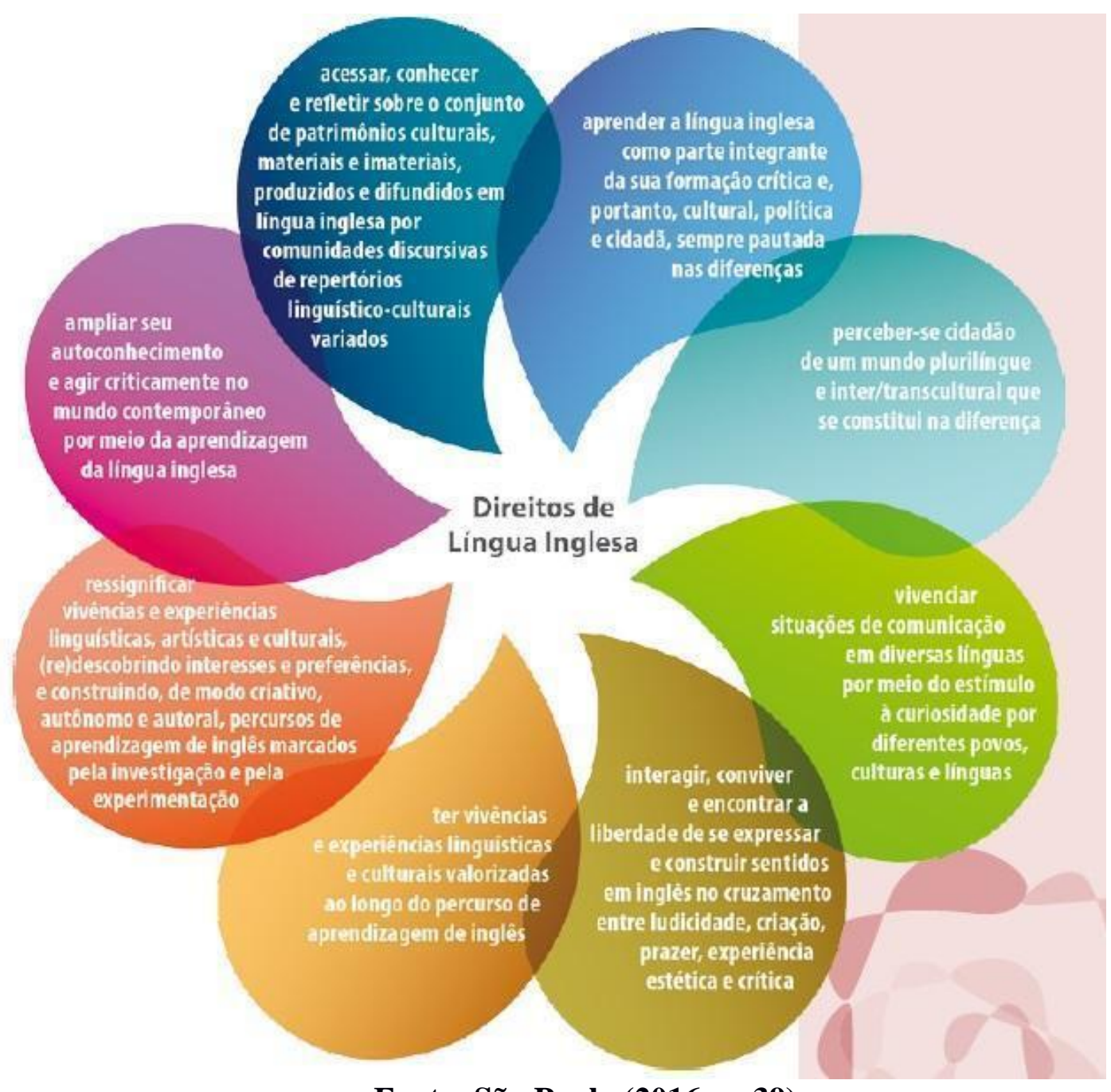

Fonte: São Paulo (2016, p. 39)

O documento explica que a intenção de desenvolver um currículo descolonizador não pretende "romper ou substituir conteúdos outrora presentes em nossas aulas, mas, sim, expandir ou ressignificar esses mesmos conteúdos possibilitando que nossos educandos e educandas tenham acesso a perspectivas outras, com vistas a ampliação de suas visões de mundo" (SÃO PAULO, 2016, p. 47), o que lembra o primeiro critério para a transmissão cultural apresentado por Dussel (2009, p. 359), segundo o qual a escola “deve ser o lugar capaz de nos por [sic] em contato com um mundo-outro, $[\ldots]$ que nos confronta com o desconhecido, o que nos permite entender e desafiar nossos limites e nos faz mais abertos aos outros e a nós mesmos". A ressignificação dos conteúdos proposta no documento também recupera o que Dussel (2009) defende como o papel da escola, de nos inserir em uma tradição e ao mesmo tempo permitir a sua reescrita e renovação.

O documento (SÃO PAULO, 2016, p. 47) prossegue sugerindo que: 
[...] ao invés de jogar fora os recursos didáticos de que já dispomos, propomos explorar suas potencialidades, trabalhando nas "brechas" desse material didático (DUBOC, 2014), ou seja, aproveitando aqueles momentos frutíferos em que percebemos uma possibilidade de provocar, de instigar, de problematizar aquilo que usualmente é posto como verdade universal. Um possível ponto de partida para um trabalho docente baseado na criatividade e na agência com recursos didáticos consiste em uma primeira sondagem sobre nossas próprias percepções do material e a maneira como podemos expandir seu uso.

Relacionamos essa afirmação ao que Sacristán (1995) entende como uma escola que realmente se preocupa em acolher a diversidade. Mais do que listar conteúdos que incluam as diferentes perspectivas culturais, ele acredita que mudanças concretas só serão alcançadas quando esse acolhimento se refletir nas atitudes daqueles envolvidos com a prática educativa, através da linguagem e exemplos utilizados, na desconstrução de estereótipos, dentre outros aspectos, o que dialoga com o que o próprio documento defende ao propor pedagogias situadas:

São pedagogias situadas porque nelas consideramos as experiências línguas - e especificamente em língua inglesa - das quais participamos os professores e os estudantes, buscamos compreendê-las, problematizá-las e analisá-las, a fim de desconstruir estereótipos e visões homogeneizantes da sociedade, das línguas e das relações entre as pessoas (SÃO PAULO, 2016, p. 44-45).

Com isso, a partir da nossa análise, podemos afirmar que tais problematizações e desconstruções só terão lugar através da atitude do professor na sua relação com os recursos didáticos, e não na simples presença da diversidade no currículo ou no livro didático.

É nesse contexto que o documento propõe percursos de planejamento em vez de, como já mencionamos, uma lista de objetos de conhecimento. O documento elege algumas práticas já desenvolvidas por docentes em serviço na rede, que partiram de algum tema, livro ou poema para desenvolver seu planejamento, criando, assim, fluxogramas, mapas conceituais ou mesmo perguntas problematizadoras, como no exemplo de um possível planejamento com base no livro Halloween, de Dirce Guedes e Ayrton Gomes, no qual as seguintes perguntas são propostas:

De qual perspectiva este livro fala? De qual nação este livro trata? Nosso país é incluído nessa representação? Nossa cidade ou bairro são incluídos nessa representação? Como estudantes interpretam essa festividade? Será algo comum ou estranho para eles? Por que certas festividades nos são comuns e outras nos parecem tão estranhas? Como será que essa festividade é vista por outros povos e culturas? (SÃO PAULO, 2016, p. 47).

A partir dessas perguntas, já é possível notar uma atitude problematizadora no percurso de planejamento. Diferentemente da perspectiva multicultural liberal mencionada por Silva (2019), em que a diversidade é constatada e celebrada, ou mesmo a interculturalidade funcional criticada por Walsh (MIGNOLO; WALSH, 2019), tais perguntas promovem o questionamento da própria diferença e de como elas são produzidas, o que fica ainda mais claro na continuação desse percurso, quando o professor: 
Descobre, por exemplo, em vários textos disponíveis online, que há diferentes formas de celebrar o Halloween. Descobre, ainda, que em determinados países africanos, por exemplo, a celebração é proibida por sua natureza eurocêntrica e a suposta ameaça a valores locais. Ao entrar em contato com essas novas perspectivas, o professorpesquisador não abandona o trabalho com o livro disponível em seu acervo, mas o reinterpreta, levando à possibilidade de ampliação de perspectivas de seus educandos e educandas ao perguntar-lhes, em uma atividade de pós-leitura: Vocês acham que todas as pessoas celebram o Halloween da forma como o livro nos conta? Será que há outras formas de celebrar essa festividade? Nós celebramos o Halloween em nosso país, nossa cidade, nosso bairro? Se sim, o que costumamos fazer? Que nome damos a essa celebração? Como será que o Halloween é celebrado em diferentes culturas? (SÃO PAULO, 2016, p. 47, 48, grifo no original).

A diferença aqui não é meramente aceita de forma condescendente, mas constantemente colocada em negociação a partir de diversas perspectivas.

Por tratar-se de um currículo que se propõe descolonizador, ou seja, que visa acarretar também práticas descolonizadoras, é possível, a partir de nossa análise, encontrar intersecções entre o que destacamos acima e o pensamento decolonial. A própria ideia de um currículo que não se pretende como universalizante, mas que seja na prática construído e desenvolvido localmente por meio de pedagogias situadas, já rompe com o pressuposto da modernidade/colonialidade de um único conhecimento verdadeiro e universal, aplicável a todos os contextos. Além disso, o documento não parte de uma teoria descolada e precedente à prática. A construção do currículo a várias mãos através de grupos de trabalho e a escolha de práticas contextualizadas demonstra o entrelaçamento dessas duas noções, que se refere ao que Walsh fala sobre o "pensar com" ou o "pensar junto" (MIGNOLO; WALSH, 2018, p. 19), além de sua intenção de:

[...] desestabilizar a noção de que estruturas teóricas e conceituais devem necessariamente proceder a práxis, assim como a ideia de que sentidos são derivados apenas conceitualmente. Começar com a práxis e com a atividade praxística de pensar-fazer, é virar a academia e o pensamento moderno ocidental de cabeça para baixo. ${ }^{89}$

Por fim, enfatizar a importância da atitude do professor nas práticas educativas ecoa a atitude decolonial proposta por Maldonado-Torres (2008 apud MIGNOLO; WALSH, 2018), que implica a adoção de diferentes perspectivas para além da ocidental, tal como no exemplo acima comentado, potencializando o que Walsh chama de interculturalidade crítica (MIGNOLO; WALSH, 2018) ou mesmo um multiculturalismo crítico, conforme Silva (2019).

Com isso, interpretamos que a proposta de um currículo descolonizador, o trabalho através de pedagogias situadas e um entendimento crítico do conceito de interculturalidade refletem o conceito de ILF presente no documento Direitos de Aprendizagem. Uma vez que tal

${ }^{89}$ [...] disturb the notion that theoretical and conceptual frameworks must necessarily precede praxis, as well as the idea that meaning is only conceptually derived. To begin with praxis and the praxistical activity of thinkingdoing, is to turn academia and Western modern thought upside down. 
conceito se assenta justamente na legitimação da diversidade e se pauta em um entendimento fluido e contextual da língua, uma política que se propõe a romper com a ideia de um conhecimento universal, valorizando a agência local e o trabalho com a interculturalidade crítica se mostra coerente com a perspectiva linguística que adota.

É importante fazer algumas ponderações a respeito de uma proposta curricular dessa natureza, evidenciando os possíveis desafios para a sua concretização. Por tratar-se de um documento que valoriza a agência local do professor e não determina previamente conteúdos, objetos do conhecimento ou objetivos de aprendizagem, é possível que muitos professores se sintam inseguros em elaborar um percurso de planejamento de modo a implementar em suas práticas uma proposta desse tipo. Para além das discussões envolvendo os profissionais da rede na elaboração do currículo, um acompanhamento formativo para todos os professores seria necessário para que as potencialidades de tal proposta fossem alcançadas. Além das formações sobre como implementar, é mais do que necessário que as condições de trabalho dos professores permitam tal implementação, envolvendo carga horária e infraestrutura suficientes para planejar e acessar materiais pertinentes às aulas.

Já na esfera nacional, a BNCC estabelece como foco principal o desenvolvimento de competências, definidas pelo próprio documento (BRASIL, 2017, p. 8) como:

[...] a mobilização de conhecimentos (conceitos e procedimentos), habilidades (práticas, cognitivas e socioemocionais), atitudes e valores para resolver demandas complexas da vida cotidiana, do pleno exercício da cidadania e do mundo do trabalho.

Elenca, para isso, dez competências gerais que devem embasar o trabalho dos diferentes componentes curriculares. A adoção do enfoque em competências alinha-se com o que é praticado pela Organização para a Cooperação e Desenvolvimento Econômico (OCDE), responsável pelo Programa Internacional de Avaliação de Alunos (Pisa), e pela Organização das Nações Unidas para a Educação, a Ciência e a Cultura (UNESCO). O diálogo com tais organismos demonstra uma preocupação com uma agenda internacional para a educação, reafirmado pelo seu alinhamento com a Agenda 2030 da ONU, principalmente no que se refere às avaliações internacionais, o que implica a necessidade de uma "indicação clara do que os alunos devem 'saber' [...] e, sobretudo, do que devem 'saber fazer'” (BRASIL, 2017, p. 13), para que, assim, seja possível também uma avaliação "clara". Tamanha clareza se manifesta através de códigos alfanuméricos que especificam cada uma das habilidades a serem desenvolvidas, relacionadas a determinados objetos de conhecimento, organizados através de tabelas para cada componente curricular e também para cada ano escolar, como vemos na Figura 7 abaixo. 
Figura 7 - Tabelas do Componente Curricular Língua Inglesa na BNCC

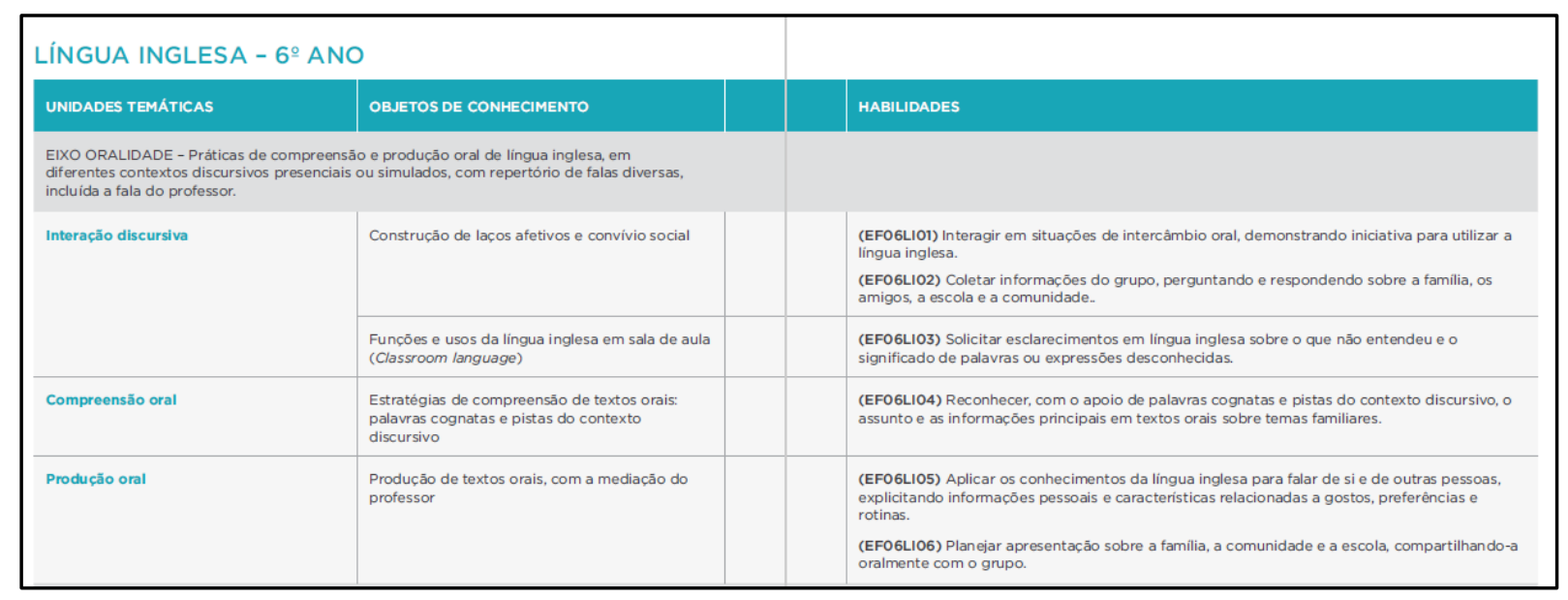

Fontes: Brasil (2017, p. 248, 249)

Libâneo (2016) problematiza a questão da internacionalização da educação, que se resume à modelação das instituições educacionais de acordo com expectativas supranacionais definidas por organismos internacionais, tais como a UNESCO, por meio de uma agenda global para a educação, tal como a Agenda 2030. Embora o autor tematize principalmente acordos e documentos dos anos 1990, muitos dos aspectos por ele levantados parecem se aplicar aqui. Estudos mencionados por Libâneo (2016) sobre esse processo apontam que essas interferências sempre objetivaram "cooperação técnica e financeira a países com dificuldades, por meio de empréstimos para realização de programas relacionados a saúde, educação, saneamento, etc." (LIBÂNEO, 2016, p. 43), como forma de diminuir as desigualdades e intensificar a globalização econômica e social, servindo à lógica do mercado e do capital internacional, já que a pobreza não colabora com o desenvolvimento da globalização. A educação, através de currículos instrumentais de resultados imediatos, busca satisfazer exigências mínimas de aprendizagem com conhecimentos úteis, a fim de alcançar resultados que garantam a rápida empregabilidade. Segundo Libâneo (2016, p. 49):

Dentro da grande armação que são as políticas de alívio da pobreza, está o currículo instrumental ou de resultados imediatos, que se caracteriza como um conjunto de conteúdos mínimos necessários ao trabalho e emprego, associado ao currículo de convívio e acolhimento social, com forte apelo à inclusão social e ao atendimento da diversidade social, visando a formar para um tipo de cidadania baseado na solidariedade e na contenção de conflitos sociais.

$\mathrm{O}$ acolhimento à diversidade torna-se uma estratégia para promover certos valores e comportamentos que previnem e apaziguam conflitos que certamente surgem no contato com o diferente, facilitando a integração social e econômica dessa população e estimulando a competitividade global. 
Prosseguindo com a organização do documento, o trabalho com a língua inglesa é dividido, no interior das tabelas, entre cinco eixos: Oralidade, Leitura, Escrita, Conhecimentos Linguísticos e Dimensão Intercultural. Para cada eixo, algumas unidades temáticas são trazidas e relacionadas a determinados objetos de conhecimento que, por sua vez, relacionam-se a determinadas habilidades. Espera-se que, entre o $6^{\circ}$ e o $9^{\circ}$ anos do Ensino Fundamental, o aluno desenvolva o total de 88 habilidades no uso da língua inglesa. O documento afirma que a numeração das habilidades "não representa uma ordem ou hierarquia esperada das aprendizagens" (BRASIL, 2017, p. 31). Entretanto, o próprio texto afirma que os verbos que expressam as habilidades tornam-se, com a passagem dos anos escolares, mais ativos e exigentes, e os objetos de conhecimento apresentam uma complexidade cada vez maior (BRASIL, 2017). No Componente Curricular Língua Inglesa, por exemplo, alguns dos verbos presentes no quadro do $6^{\circ}$ ano são, dentre outros, "localizar", "aplicar", "descrever" e “reconhecer”. Já no 9ªno, os verbos utilizados são “debater", “discutir”, “propor” e "expor”. A complexificação dos verbos utilizados ao longo dos anos expressa um entendimento dos processos de aprendizagem que pressupõe a existência de habilidades mais simples e outras mais complexas, indicando uma gradação e linearidade na construção do conhecimento. O uso de tabelas dividindo os anos escolares por si só já indica esse pressuposto de sequenciação. Além disso, tal forma de organização dos objetos de conhecimento manifesta o caráter normatizador e padronizador do documento, que pretende garantir aprendizagens comuns, consideradas essenciais para todos os educandos, independente de questões contextuais e locais.

A respeito dessa divisão por eixos e da progressão dos conteúdos, percebemos também diferentes perspectivas por parte dos leitores críticos do documento. Para Francini (2017), a organização dos objetivos de aprendizagem através de eixos é vista como inovadora, enquanto Durazzo (2017) e Coutinho e Gimenez (2017) problematizam esse aspecto. Para a primeira parecerista que questiona tal orientação, essa fragmentação pode levar a uma fragmentação também no planejamento das situações de aprendizagem. Para as outras duas pareceristas, tal divisão não é coerente com a abordagem de língua proposta, que considera a língua como um todo e como prática social. A separação de um eixo para conhecimentos linguísticos pode levar a uma priorização desse aspecto por parte do professor, não contribuindo para superação de uma visão estrutural de língua. Duboc (2016) também critica a hiperfragmentação no documento, pois não condiz com a multimodalidade e a interdisciplinaridade requerida pela sociedade contemporânea.

Partindo da perspectiva da neurociência, a progressão é analisada por Francini (2017) através dos verbos operatórios empregados nas habilidades, muitos dos quais ele considera 
indicar habilidades de pensamento de ordem mais inferior. Embora ele concorde que deva haver uma progressão de objetos de conhecimento, ele critica o fato de alguns conteúdos serem propostos antes de outros. Ou seja, é apontada uma falta de linearidade. Já Durazzo (2017) elogia a progressão das habilidades dentro de cada eixo, iniciado com o que ela considera ser um repertório de língua básico até chegar em uma competência oral mais sofisticada. Seguindo essa mesma lógica, ela sugere que o presente perfeito seja ensinado no $9^{\circ}$ ano, e não no $7^{\circ}$ ano como posto na versão em questão, pela Língua Portuguesa não ter um tempo verbal correspondente, o que inferimos tratar-se, portanto, de um conhecimento mais sofisticado ou complexo. Coutinho e Gimenez (2017), por sua vez, consideram que há repetição nas unidades temáticas e nos objetivos de aprendizagem distribuídos ao longo dos anos e que alguns objetivos do $8^{\circ}$ ano, por exemplo, oferecem menor complexidade que os do $6^{\circ}$ ano. Com base nisso, as últimas pareceristas propõem uma reformulação na progressão das habilidades referentes a cada eixo, iniciando com propostas relacionadas ao próprio educando e seu entorno para, posteriormente, abranger experiências de outros e de temas mais gerais. Para Duboc (2016), o sequenciamento proposto segue uma convencional lógica de gradação, e sugere uma gradação de natureza dialógica e espiralada. Para ela, os conhecimentos linguísticos deveriam surgir das práticas de letramento locais e não serem previamente determinados pelo documento. A respeito dessa linearidade, gradação e progresso na aprendizagem, recuperamos algumas problematizações já feitas no capítulo anterior. Com base em Canagarajah e Wurr (2011) e Canagarajah (2017) afirmamos que essas noções têm como pressuposto que na aprendizagem de línguas há um objetivo final a ser alcançado, ancorado nas regras gramaticais da língua e na valoração de certas estruturas como simples ou complexas. Como vimos, em oposição a essa perspectiva, há um entendimento situacional da aprendizagem e das interações na língua, ancorado nos contextos de uso da língua e não no seu sistema.

Quando contrastamos essa proposta de trabalho organizada em quadros com o texto introdutório do componente Língua Inglesa no qual o conceito de ILF é proposto, atestamos a presença de uma contradição no interior do documento. A organização em tabelas, com seu caráter enrijecedor e padronizador, se mostra claramente contraditória em relação à natureza fluida, híbrida e contextual de ILF tal como o conceito é definido no próprio texto.

Tal contradição é notada não só na questão estrutural do documento, mas também na própria descrição das habilidades. Primeiramente, se partimos de uma visão de língua que considera as formas linguísticas emergentes do contexto de uso, como é o caso do conceito de ILF aqui proposto, estabelecer previamente os objetos do conhecimento a serem aprendidos, tais como adjetivos possessivos, verbo modal can (passado e futuro), quantificadores e 
pronúncia, da maneira como é feito no documento, contraria essa mesma visão de língua adotada. A descrição de algumas das habilidades relacionadas a esses objetos de conhecimento também reafirma essa incongruência. Os verbos normalmente usados para expressar as habilidades no uso da gramática são "utilizar" e "empregar", seguidos das expressões "de modo inteligível" ou "de forma inteligível" e o conteúdo gramatical em questão, como na seguinte descrição: “(EF09LI16) Empregar, de modo inteligível, os verbos should, must, have to, may e might para indicar recomendação, necessidade ou obrigação e probabilidade" (BRASIL, 2017, p. 261). De fato, pautar-se na perspectiva de ILF implica a valorização da inteligibilidade em detrimento da correção e da precisão linguística. Entretanto, o próprio fato de estabelecer previamente determinadas formas gramaticais já é incoerente com essa mesma perspectiva, uma vez que as formas linguísticas são entendidas como emergentes da interação, e não préestabelecidas. Desse modo, o que é ou não inteligível depende da situação comunicativa e dos sujeitos nela envolvidos. Além disso, ao indicar as situações de uso dessas formas, os sentidos tornam-se fixos, contrariando mais uma vez uma perspectiva que considera os sentidos produzidos na situação discursiva.

Apesar de enfatizar, como dissemos, a inteligibilidade em detrimento da correção, nos deparamos com a seguinte descrição em uma das habilidades a serem desenvolvidas: “(EF08LI16) Utilizar, de modo inteligível, corretamente, some, any, many, much" (BRASIL, 2017, p. 257, grifo nosso). Embora o uso das expressões “de modo inteligível” e "corretamente" apareça apenas essa vez, como se fosse um rastro deixado no documento, não podemos deixar de notar essa ocorrência, que demonstra, mais uma vez, uma contradição interna no documento, uma vez que cada uma dessas expressões representa uma perspectiva de ensino diferente, ILF em oposição a ILE.

A respeito dos aspectos didático-metodológicos, a BNCC não estabelece uma abordagem única a ser seguida. Essa falta de prescrição é avaliada de diferentes formas pelos pareceristas envolvidos, indicando visões distintas a respeito da função de um documento regulador. Francini (2017) sugere que se adote a abordagem do CLIL (Content and Language Integrated Learning) ${ }^{90}$, enquanto Durazzo (2017) recomenda o trabalho com projetos. Para Coutinho e Gimenez (2017), por tratar-se de um documento de natureza mais abrangente, elas não recomendam que os aspectos metodológicos sejam detalhados, mas sugerem que se adote uma perspectiva sociocultural de aprendizagem. Duboc (2016) não comenta especificamente a

\footnotetext{
90 Termo criado em 1994 por David Marsh e promovida pela Comissão Europeia em que se integra a aprendizagem de uma língua adicional através de conteúdos.
} 
respeito dessa questão, mas critica o caráter prescritivo e universalizante do documento, temendo pela perda da agência dos professores em seus contextos locais. Enquanto Duboc (2016) valoriza o espaço de agência e interpretação do professor, Francini (2017) parte de uma perspectiva que parece querer limitar essa possibilidade, uma vez que critica o uso do verbo "avaliar" em uma das habilidades uma vez que "deixa espaço para que a ação ocorra de modos diferentes, dependendo da interpretação dos professores e dos autores de materiais didáticos" (FRANCINI, 2017, p. 6), valorizando, ao contrário de Duboc (2016), uma maior prescrição por parte da BNCC.

Um outro ponto de discordância entre os pareceristas diz respeito à função de avaliação ou medição do nível de proficiência linguística dos alunos. Francini (2017), Durazzo (2017) e Coutinho e Gimenez (2017) defendem que o componente Língua Inglesa se alinhe a padrões internacionais, como o Quadro Europeu Comum de Referência para Línguas (CEFR). Para Durazzo (2017, n. p.), tal documento "dialoga harmonicamente com a BNCC"; para Coutinho e Gimenez (2017), os dois documentos possuem uma similaridade estrutural que facilitaria o trabalho de avaliar o atingimento das metas. Duboc (2016) não faz menção ao documento europeu e, no que diz respeito à noção de proficiência, a parecerista problematiza a menção ao termo, assim como de "aquisição" e "domínio", uma vez que tais noções, caras às teorias tradicionais de aquisição de língua, não dialogam com a perspectiva de ILF adotada no próprio documento.

Uma vez que compreendemos o conflito epistemológico instaurado no documento, é possível entender essas duas perspectivas como viáveis, a depender do aspecto da BNCC que for enfatizado. Enquanto documento normatizador e prescritivo de conhecimentos fixos e estáveis, ele se mostra, de fato, alinhado ao Quadro Europeu Comum de Referência para Línguas, como sugerem os três primeiros pareceres mencionados, embora a BNCC não faça referência explícita a esse documento. Porém, se considerarmos a perspectiva fluida, emergente e contextual trazida pela presença de ILF no componente curricular, além do objetivo declarado de romper com o eurocentrismo no ensino de inglês, tal alinhamento se faz incoerente, como defende a última parecerista.

Voltamo-nos agora à questão da interculturalidade e a como a BNCC sugere o seu trabalho. Como já mencionamos, a competência intercultural que o documento almeja desenvolver é proposta na tabela através do Eixo Dimensão Intercultural, que propõe a "reflexão sobre aspectos relativos à interação entre culturas (dos alunos e aquelas relacionadas a demais falantes de língua inglesa), de modo a favorecer o convívio, o respeito, a superação de conflitos e a valorização da diversidade entre os povos" (BRASIL, 2017, p. 248). Tal 
descrição parece ecoar a perspectiva multiculturalista de currículo mencionada por Silva (2019), em que a diferença é tratada como motivo de celebração, restando apenas respeitá-la. De uma perspectiva decolonial, a relação com a diferença é sempre conflituosa, o que não necessariamente significa que tais conflitos devam ser superados, como descrito no objetivo desse eixo. Segundo Walsh, a interculturalidade coloca em diálogo, ainda de forma conflituosa, diversas formas de saber, pensar, ser e viver. As diferenças, portanto, não são apagadas, mas permanente e ativamente negociadas (MIGNOLO; WALSH, 2018).

Embora no texto introdutório seja declarada a intenção de promover "a compreensão de como elas [as diferenças] são produzidas nas diversas práticas sociais de linguagem” (BRASIL, 2017, p. 240), o que o documento propõe como trabalho no eixo intercultural parece manifestar, na verdade, a interculturalidade funcional descrita por Walsh (MIGNOLO; WALSH, 2018), ainda mais quando associada a políticas de internacionalização da educação conforme nos alerta Libâneo (2016), nos colocando diante do que parece ser um currículo instrumental de resultados imediatos.

Com base na discussão acima, entendemos que o sentido de ILF pretendido no texto introdutório do componente curricular é refratado quando inserido em um documento normatizador como a BNCC, gerando o que acreditamos tratar-se, conforme Duboc (2019, p. 17), de um conflito epistemológico, pois:

[...] como pode um documento acolher os usos criativos, híbridos e locais do inglês em seu status de língua franca se o próprio documento organiza, linear e hierarquicamente, temas, objetos de conhecimento e habilidades, com exemplos de conteúdos linguísticos fixos e estáveis?

Além disso, ao ser articulado a um entendimento funcional de interculturalidade, a potencialidade crítica e política do conceito de ILF, ecoando as teorizações do ILF feito no Brasil (DUBOC, 2019), é deslocada.

Vejamos agora como o Currículo da Cidade, de volta ao nível municipal, lida com essas mesmas questões. Para conceber o currículo, o documento elenca algumas de suas características, afirmando que currículos são plurais, orientadores, não lineares e sempre em transformação (SÃO PAULO, 2017).

O documento apresenta também o conceito de equidade sob o qual ele se assenta, em que as diferenças são compreendidas e reconhecidas como inerentes à humanidade, e pressupõe a igualdade de oportunidades para que todos aprendam. Com base nisso, o documento (SÃO PAULO, 2017, p. 23) afirma contemplar:

[...] o respeito à diversidade humana, considerando que os sujeitos devem ser valorizados pela sua heterogeneidade quanto ao gênero, etnia, cultura, deficiência, religião, entre outras particularidades. O não reconhecimento da diversidade na escola 
pode ser gerador de discriminação e exclusão do estudante e, assim, contribuir para aprofundar as desigualdades educacionais ao invés de combatê-las.

Vemos, até então, que o pressuposto da diferença como constitutiva dos sujeitos parece sugerir um currículo pautado na orientação sociológica/intercultural como no documento que o precede. Entretanto, é preciso atentar para como o documento entende essa diversidade, como ele se estrutura e como isso é articulado com outros aspectos nele presentes.

Para entendermos a noção de diversidade no Currículo da Cidade, vale observar brevemente dois aspectos relevantes que o documento defende quando apresenta sua concepção de currículo. O texto afirma que os "professores são protagonistas do currículo" (SÃO PAULO, 2017, p. 18), pois cabe a eles implementar o currículo, contextualizando o aprendizado na sua relação com os estudantes. Logo depois, considera-se que "currículos devem ser centrados nos estudantes" (SÃO PAULO, 2017, p. 19), a fim de assegurar sua aprendizagem e desenvolvimento, "precisam dialogar com a realidade das crianças e adolescentes, de forma a conectarem-se com seus interesses, necessidades e expectativas" (SÃO PAULO, 2017, p. 19).

Embora os trechos do documento acima destacados afirmem a centralidade dos alunos no currículo, o texto também permite compreender que é do professor a responsabilidade em estabelecer essa relação entre o conhecimento e os estudantes, o que é reforçado quando se apresenta o que é entendido como diversidade. O documento (SÃO PAULO, 2017, p. 23) afirma que:

[...] o currículo deve ser concebido como um campo aberto à diversidade, a qual não diz respeito ao que cada estudante poderia aprender em relação a conteúdos, mas sim às distintas formas de aprender de cada estudante na relação com seus contextos de vida. Defende-se, portanto, a apresentação de conteúdos comuns a partir de práticas e recursos pedagógicos que garantam a todos o direito ao aprendizado e ao desenvolvimento integral. Para efetivar esse processo de mediação pedagógica, ao planejar, o professor precisa considerar as diferentes formas de aprender, criando, assim, estratégias e oportunidades para todos os estudantes. Tal consideração aos diferentes estilos cognitivos faz do professor um pesquisador contínuo sobre os processos de aprendizagem.

Essa compreensão de diversidade, portanto, não visa representar a diferença cultural no currículo, mas sim garantir que as diferentes formas de aprender sejam acolhidas. Como explicita o trecho acima, porém, essa responsabilidade é do professor; é ele que precisa criar as oportunidades de aprendizagem levando em conta as diferenças. Além disso, o documento também defende que se apresentem conteúdos comuns a todos os alunos que garantam seu aprendizado, ecoando, na nossa visão, o multiculturalismo assimilacionista de Candau (2008), em que o caráter monocultural da educação, no que se refere aos conteúdos do currículo e sua dinâmica, não é questionado. Além disso, novamente o conceito de interculturalidade funcional 
de Walsh (2012) emerge, uma vez que se trata aqui de garantir que a diferença seja incluída na monocultura.

De forma semelhante à BNCC, o Currículo da Cidade propõe, para cada ano do Ensino Fundamental, um quadro (Figura 8) que organiza o trabalho na disciplina, no qual se estabelecem, distribuídos em quatro eixos (Práticas de Linguagem oral - produção e escuta; Práticas de leitura de textos; Práticas de análise linguística; e Dimensão intercultural), os Objetos de conhecimento e os Objetivos de aprendizagem e desenvolvimento, que serão explorados adiante na nossa análise.

Figura 8 - Quadro de objetivos de aprendizagem e desenvolvimento

\begin{tabular}{|c|c|c|c|}
\hline Eixos & $\begin{array}{l}\text { Objetos } \\
\text { de Conhecimento }\end{array}$ & Objetivos de Aprendizagem e Desenvolvimento & $\begin{array}{l}\text { Objetivos de } \\
\text { Desenvolvimento } \\
\text { Sustentável }\end{array}$ \\
\hline \multirow{6}{*}{$\begin{array}{l}\text { PRÁTICASDE } \\
\text { LINGUAGEM } \\
\text { ORAL- } \\
\text { PRODUÇÃOE } \\
\text { ESCUTA }\end{array}$} & \multirow[t]{2}{*}{ Convívio social } & EFEJAECLI01) Conhecer e utilizar saudações e cumprimentos. & \\
\hline & & $\begin{array}{l}\text { (EFEJAECLIO2) Interagir com o professor e colegas de forma respeitosa, } \\
\text { utilizando expressões, tais como: Excuse me, Please, } \\
\text { Thank you. }\end{array}$ & \\
\hline & $\begin{array}{l}\text { Contextos de uso: } \\
\text { sala de aula } \\
\text { (Classroom language) }\end{array}$ & $\begin{array}{l}\text { (EFEJAECLIO3) Utilizar expressões para solicitar a ajuda do professor a } \\
\text { fim de esclarecer dúvidas sobre a Língua Inglesa. }\end{array}$ & \\
\hline & \multirow[t]{3}{*}{ Interação discursiva } & $\begin{array}{l}\text { (EFEJAECLIO4) Conhecer os colegas, perguntando e respondendo sobre } \\
\text { informações pessoais (nome, idade, origem, profissão, estado civil, data } \\
\text { e local de nascimento, a familia, dentre outras). }\end{array}$ & [1]| \\
\hline & & $\begin{array}{l}\text { (EFEJAECLI05) Investigar as preferências e gostos dos colegas relativos } \\
\text { a hobbies, lazer, alimentação e cultura (por exemplo, na música, } \\
\text { esportes, cinema). }\end{array}$ & 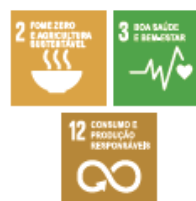 \\
\hline & & (EFEJAECLI06) Conversar sobre rotinas diárias. & 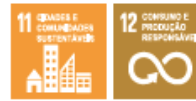 \\
\hline
\end{tabular}

\section{Fonte: São Paulo (2017, p. 83)}

A listagem de tais objetos de conhecimento, desmembrados em objetivos de aprendizagem e até mesmo o estabelecimento de determinadas estruturas linguísticas para cada função comunicativa, pode nos levar a entender essa proposta com base na orientação dialéticocrítica na formulação de currículos apresentada e defendida por Libâneo (2016), a qual visa garantir a apropriação dos saberes socialmente construídos.

Entretanto, a última coluna do quadro relaciona alguns desses objetivos de aprendizagem aos Objetivos de Desenvolvimento Sustentável (ODS), estabelecidos na Agenda 2030 pelos países que compõem a Organização das Nações Unidas e articulados à proposta da UNESCO de uma Educação para o Desenvolvimento Sustentável (EDS), fazendo-nos refletir 
sobre a influência de organismos internacionais no âmbito local de educação. Segundo o documento (SÃO PAULO, 2017, p. 37):

Esses objetivos estão compreendidos em 169 metas ambiciosas para cumprimento pelos países-membros da Organização das Nações Unidas (ONU). A integração do Currículo da Cidade com os Objetivos de Desenvolvimento Sustentável se dá tanto por escolhas temáticas de assuntos que podem ser trabalhados em sala de aula nos diversos componentes curriculares, quanto na escolha das metodologias de ensino que priorizem uma educação integral, em consonância com a proposta de Educação para o Desenvolvimento Sustentável (EDS) da UNESCO. A EDS traz uma abordagem cognitiva, socioemocional e comportamental e busca fomentar competências-chave para atuação responsável dos cidadãos a fim de lidar com os desafios do século XXI.

O texto apresenta então as oito competências-chave mencionadas, que referem-se à competência de pensamento sistêmico, antecipatória, normativa, estratégica, de colaboração, de pensamento crítico, de autoconhecimento e de resolução integrada de problemas. Elas articulam-se aos 17 ODS, que visam, por exemplo, diminuir as desigualdades, erradicar a pobreza, oferecer educação, saúde e condições básicas de sobrevivência, e preservar o meio ambiente.

Cabe aqui a mesma crítica que fizemos anteriormente à BNCC com base em Libâneo (2016) sobre a influência de organismos internacionais na educação, acarretando currículos instrumentais de resultados imediatos. Ainda segundo esse autor, ressaltamos a preocupação do documento em atender as diversas formas e ritmos de aprendizagem, o que associamos à atitude de benevolência com as dificuldades por parte dos professores que Libâneo (2016, p. 56-57) comenta:

\footnotetext{
"Vamos ter paciência, as crianças pobres são diferentes, elas têm sua cultura, suas características sociais e raciais, seus ritmos, elas precisam de um ensino diferenciado". Nesse raciocínio, para atender às diferenças é preciso um ensino mais facilitado, mais tolerância na avaliação, etc., o que pode levar à estigmatização das diferenças, privando os alunos pobres do direito à igualdade entre os seres humanos. Isso acaba sendo uma atitude de discriminação dos pobres.
}

Desse modo, um ensino mais tolerante nesse sentido apenas contribuiria com o aumento da desigualdade que o próprio currículo e os programas a ele associados afirmam querer combater.

À luz desse entendimento, voltamos agora à forma de organização do trabalho com a língua inglesa proposta pelo currículo e a sua relação com o conceito de Inglês como Língua Franca. Como mencionado, ao propor, em seu texto introdutório, o estudo do inglês em seu status de língua franca, o documento enfatiza a possibilidade de agenciamento crítico, do estudo da língua além de questões estruturais e funcionais, da desterritorialização do idioma, e da problemática de um único inglês "correto" trazidos por esse paradigma (SÃO PAULO, 2017). Entretanto, grande parte do que é proposto como forma de desenvolvimento do trabalho com a 
Língua Inglesa aproxima-se de uma abordagem semelhante à do Inglês como Língua Estrangeira, conforme argumentamos a seguir.

Como mencionado anteriormente, embora recupere elementos importantes do Direitos de Aprendizagem, é notável a influência das orientações da BNCC na construção desse currículo, mesmo que o documento federal afirme que "os agrupamentos propostos não devem ser tomados como modelo obrigatório para o desenho dos currículos" (BRASIL, 2017, p. 31). Além da organização estruturada em tabelas, tal influência se manifesta na semelhança entre os Eixos, os Objetos de conhecimento e os Objetivos de Aprendizagem e Desenvolvimento no Currículo da Cidade e os Eixos, Objetos de conhecimento e Habilidades presentes na BNCC. Mesmo que não seja em sua totalidade, muitos dos Objetivos de Aprendizagem e Desenvolvimento coincidem com as Habilidades propostas na BNCC, por vezes trazendo até o mesmo texto.

Enquanto se assemelha à organização do documento federal, o Currículo da Cidade se distancia do documento municipal que o precede. Tais diferenças são acentuadas até mesmo visualmente. Se no documento de 2016 os direitos de aprendizagem são dispostos circularmente por meio de uma figura que lembra uma flor, como mostramos na Figura 6, implicando uma não-hierarquização e não-linearidade, o currículo de 2017 privilegia, através dessas tabelas, seus conteúdos e habilidades de forma hierárquica e linear.

A mesma problematização que fizemos à BNCC referente ao seu caráter normatizador e restritivo vale para o documento municipal aqui analisado, mas isso se torna ainda mais evidente no caso do Currículo da Cidade, pois ao estabelecer os Objetivos de Aprendizagem e Desenvolvimento, são também determinadas as estruturas gramaticais correspondentes a funções comunicativas específicas. Destacamos algumas delas para fins de exemplificação: "Perguntar e responder a origem (Where are you from? Guaianases. / Where is this story from? Canada)" (SÃO PAULO, 2017, p. 77); "Reconhecer a pronúncia de verbos regulares no passado (-ed)" (SÃO PAULO, 2017, p. 86); “Utilizar formas verbais do futuro (going to e will) para descrever planos e expectativas e fazer previsões" (SÃO PAULO, 2017, p. 89); e "Utilizar, adequadamente, os quantificadores some, any, many, much" (SÃO PAULO, 2017, p. 89).

Tal proposta contradiz aquilo que o próprio documento apresenta na sua concepção de língua, segundo a qual “o sujeito não mais 'codifica' ou 'identifica' o que lhe foi comunicado com base em modelos previamente definidos, mas 'significa', 'interpreta', 'reinventa' os sentidos de modo situado" (SÃO PAULO, 2017, p. 68), mesma concepção apresentada na proposta curricular da gestão anterior (SÃO PAULO, 2016). 
Como enfatizamos anteriormente, a noção de diferença entendida pelo currículo como as diversas formas de acessar o conhecimento e o pré-estabelecimento de determinados conteúdos mínimos de aprendizado nos faz perceber que estamos, de fato, diante de um currículo instrumental de resultados imediatos como mencionado por Libâneo (2016). Seu objetivo é apenas garantir o acesso dos sujeitos a tais conteúdos, que devem ser os mesmos a todos, considerando suas diferentes formas de aprender, para que desenvolvam determinadas habilidades e competências que os ajudarão a se ajustar à sociedade, promovendo a empregabilidade e o desenvolvimento econômico.

Desse modo, é possível concluir que o conceito de ILF, que compreende a língua como híbrida, fluida, com uma função política, social e cultural, é refratado e a intenção declarada no próprio documento de uma ressignificação no papel do inglês é deslocada por uma abordagem que reflete os "bons velhos hábitos" no ensino de línguas estrangeiras (JORDÃO; MARQUES, 2018), através de estruturas prévias e descontextualizadas e com significados prontos, atribuindo uma função estritamente instrumental e/ou mercadológica para o inglês, gerando, assim como na BNCC, um conflito epistemológico (DUBOC, 2019).

Para analisar a presença do conceito de ILF nessas propostas, recuperamos a noção de campo de Bourdieu (2004) trazida no início do capítulo. Como mencionado, o campo é considerado pelo autor como um mundo social que responde às pressões externas, mas dotado também de certa autonomia. Dessa forma, entendemos as políticas educacionais como "um campo de forças e um campo de lutas para conservar ou transformar esse campo de forças" (BOURDIEU, 2004, p. 22-23), capaz de refletir e refratar os debates externos a elas.

Nas propostas curriculares aqui analisadas, a reflexão ou refração se dá pelas bases epistemológicas dos documentos e do conceito de ILF neles inserido. No caso do Currículo da Cidade e da BNCC, em que identificamos um conflito epistemológico no componente língua inglesa, é possível entender esse conflito como característico do campo e suas lutas. Nesse sentido, embora haja uma contradição interna nessas propostas, atestada pela presença de um entendimento fluido e dinâmico de língua em documentos com características padronizadoras e estáticas, podemos avaliá-la de forma positiva, como reflexo das lutas epistemológicas entre os agentes e instituições envolvidas na produção de políticas educacionais. Como observamos nos pareceres recebidos pelo Ministério da Educação, mesmo entre os envolvidos no processo de produção há divergências epistemológicas que, de certa forma, são transparecidas no documento final. E como acreditamos que as políticas educacionais também refletem o contex to histórico, social e político que as produzem, a construção de currículos sob a gestão de governos com políticas alinhadas a uma agenda neoliberal se constitui também como uma das forças que 
influenciam esse campo, favorecendo uma concepção instrumental de currículo e, no caso da língua inglesa, uma função instrumental para a aprendizagem do idioma com vistas a uma possível inserção social através do mercado.

Para concluir, apresentamos o Quadro 1 a seguir, que sintetiza os argumentos desenvolvidos ao longo do capítulo, como forma de representar visualmente as comparações estabelecidas.

Quadro 1 - Comparação entre os três documentos reguladores analisados

\begin{tabular}{|c|c|c|c|}
\hline & $\begin{array}{l}\text { Direitos de } \\
\text { aprendizagem } \\
\text { dos ciclos } \\
\text { interdisciplinar e } \\
\text { autoral (2016) }\end{array}$ & $\begin{array}{c}\text { Base Nacional } \\
\text { Comum Curricular } \\
\text { (2017) }\end{array}$ & $\begin{array}{l}\text { Currículo da } \\
\text { Cidade } \\
\text { (2017) }\end{array}$ \\
\hline LÍNGUA & Prática social & "Prática social" & "Prática social" \\
\hline LETRAMENTO & $\begin{array}{l}\text { Pedagogia crítica; } \\
\text { letramento crítico; } \\
\text { Multiletramentos. }\end{array}$ & Multiletramentos. & $\begin{array}{l}\text { Multiletramento, } \\
\text { multimodalidade. }\end{array}$ \\
\hline $\begin{array}{l}\text { PRODUÇÃO } \\
\text { SENTIDOS }\end{array}$ & $\begin{array}{l}\text { Produção de } \\
\text { sentidos situados, } \\
\text { interpretação, } \\
\text { multiplicidade de } \\
\text { sentidos. }\end{array}$ & $\begin{array}{l}\text { "Produção de } \\
\text { sentidos de modo } \\
\text { situado, } \\
\text { interpretados e } \\
\text { reinventados pelo } \\
\text { sujeito". }\end{array}$ & $\begin{array}{l}\text { "Produção de } \\
\text { sentidos situados em } \\
\text { vez de codificação } \\
\text { de modelos pré- } \\
\text { determinados". }\end{array}$ \\
\hline APRENDIZAGEM & $\begin{array}{l}\text { Baseado na noção } \\
\text { de direitos, } \\
\text { pedagogias } \\
\text { situadas. }\end{array}$ & $\begin{array}{l}\text { Baseado na noção } \\
\text { de competências; } \\
\text { Agenda } 2030 \\
\text { UNESCO para o } \\
\text { desenvolvimento } \\
\text { sustentável. }\end{array}$ & $\begin{array}{c}\text { Baseado na noção } \\
\text { de competências; } \\
\text { Agenda } 2030 \\
\text { UNESCO para o } \\
\text { desenvolvimento } \\
\text { sustentável. }\end{array}$ \\
\hline CURRÍCULO & $\begin{array}{l}\text { Currículo bottom- } \\
\text { up, ênfase na } \\
\text { experiência. }\end{array}$ & $\begin{array}{l}\text { Currículo }{ }^{91} \text { top- } \\
\text { down, ênfase no } \\
\text { conteúdo. }\end{array}$ & $\begin{array}{l}\text { Currículo top-down, } \\
\text { ênfase no conteúdo. }\end{array}$ \\
\hline $\begin{array}{l}\text { DIFERENÇA/ } \\
\text { DIVERSIDADE }\end{array}$ & $\begin{array}{l}\text { Vozes, povos, } \\
\text { culturas, } \\
\text { contextos. }\end{array}$ & Culturas, povos. & $\begin{array}{c}\text { Estilos de } \\
\text { aprendizagem. }\end{array}$ \\
\hline $\begin{array}{l}\text { INTER- } \\
\text { CULTURALIDADE }\end{array}$ & $\begin{array}{l}\text { Interculturalidade } \\
\text { crítica. }\end{array}$ & $\begin{array}{l}\text { Interculturalidade } \\
\text { funcional. }\end{array}$ & $\begin{array}{l}\text { Interculturalidade } \\
\text { funcional. }\end{array}$ \\
\hline
\end{tabular}

\footnotetext{
${ }^{91}$ Embora a BNCC não seja oficialmente considerada como um currículo, mas sim um documento norteador para a elaboração de currículos locais, o fato de determinar previamente os objetos de conhecimento em quadros faz com que eles se tornem fixos e estáveis e, na prática, o documento pode se tornar um currículo, limitando a agência local de cada contexto escolar.
} 


\begin{tabular}{|l|c|c|c|}
\hline SOCIEDADE & Sociedade pós- \\
moderna. & $\begin{array}{c}\text { Sociedade a ser } \\
\text { transformada pelo } \\
\text { desenvolvimento } \\
\text { econômico. }\end{array}$ & $\begin{array}{c}\text { Sociedade da } \\
\text { informação: acesso a } \\
\text { novas tecnologias de } \\
\text { comunicação e } \\
\text { informação; } \\
\text { desenvolvimento } \\
\text { econômico. }\end{array}$ \\
\hline CONHECIMENTO & $\begin{array}{c}\text { Conhecimento } \\
\text { como uma } \\
\text { construção social } \\
\text { instável. }\end{array}$ & $\begin{array}{c}\text { Conhecimentos } \\
\text { prontos, fixos e } \\
\text { estáveis. }\end{array}$ & $\begin{array}{c}\text { Conhecimentos } \\
\text { prontos, fixos e } \\
\text { estáveis. }\end{array}$ \\
\hline SUJEITO & $\begin{array}{c}\text { Professor / autor / } \\
\text { pesquisador. } \\
\text { Aluno formado } \\
\text { para problematizar } \\
\text { a sociedade. }\end{array}$ & $\begin{array}{c}\text { Pluno formado para } \\
\text { Alunclusão na } \\
\text { sociedade produtiva. }\end{array}$ & $\begin{array}{c}\text { Aluno formado para } \\
\text { a inclusão na } \\
\text { sociedade produtiva. }\end{array}$ \\
\hline
\end{tabular}

Fonte: elaboração própria 


\section{CONSIDERAÇÕES FINAIS}

O objetivo desta pesquisa foi compreender as diferentes bases epistemológicas e ontológicas nas quais o conceito de ILF se insere, na própria literatura sobre o tema e em diferentes propostas curriculares, através de duas perguntas norteadoras: a primeira buscou compreender esses aspectos na própria produção científica de ILF, desde sua gênese através de duas pesquisadoras da área no contexto europeu, passando por pesquisas desenvolvidas em outros contextos, até a sua ressignificação por pesquisadores brasileiros. A segunda investigou como o conceito foi apropriado por diferentes documentos reguladores da Educação Básica brasileira, nas esferas municipal e federal. Para responder essas perguntas, com inspiração no paradigma indiciário, lançamos um olhar detetivesco à produção bibliográfica sobre ILF, à programação do evento International Conference of ELF, aos documentos reguladores brasileiros e a alguns pareceres críticos referentes a esses documentos a fim de identificar as concepções que os sustentam, a partir da perspectiva teórica do pensamento decolonial e da Linguística Aplicada Crítica.

Ao nos voltarmos para as questões epistemológicas do conceito de ILF, identificamos, através de determinados indícios, os diferentes sentidos circulantes de ILF que refletem diferentes modos de conceber a língua e o conhecimento. Em algumas definições, é possível depreender uma noção de conhecimento objetivo, descolado do sujeito e com intenções universalizantes característica da produção moderna/colonial de conhecimento, e de uma ideia de língua enquanto sistema capaz de ser descrito e codificado, enrijecendo seus sentidos. Outras teorizações partem de um conhecimento local, situado e contextualizado, e de um entendimento de língua enquanto produção e negociação de sentidos, que emergem na particularidade de cada interação discursiva. Mais do que aparentes mudanças na forma de definir o conceito ou mesmo a adoção de um novo conceito, entendemos que são esses diferentes pressupostos que alteram profundamente o que se entende por ILF. E apesar do campo científico sobre o tema ter passado por diferentes fases com reformulações de seus objetivos, é possível identificar que os diferentes sentidos atribuídos a ILF coexistem em diferentes trabalhos e até em um mesmo estudo, revelando uma complexa teia de significações em seu entorno.

No que diz respeito às questões ontológicas, percebemos como a colonialidade opera na própria produção de conhecimento sobre ILF, com uma forte predominância de pesquisadores provenientes do Norte Global, majoritariamente do Reino Unido. Por isso, não basta olharmos para o conceito sem também nos voltarmos para os sujeitos que os enunciam. Sem esse olhar, não percebemos como a matriz colonial de poder e do saber é perpetuada, com a legitimação 
de determinados conhecimentos em detrimento de outros. Não percebemos que vozes não estão sendo ouvidas e quais sentidos estão sendo excluídos do debate no entorno de ILF.

Quando nos dedicamos à análise da apropriação de ILF por diferentes propostas curriculares no âmbito das políticas educacionais brasileiras, constatamos novamente que seu sentido varia a depender das bases epistemológicas e ontológicas em que se insere. A pesquisa documental, também articulada ao paradigma indiciário, nos mostrou como o conceito pode ser apropriado discursivamente e servir a agendas educacionais distintas. Retomando as noções de conhecimento, sujeito e sociedade consideradas por Silva (2019) como a base de qualquer currículo, identificamos que, no caso do Direitos de Aprendizagem dos ciclos interdisciplinar e autoral, estamos diante de um documento que questiona a ideia de um conhecimento objetivo e universal, privilegiando saberes locais e práticas contextualizadas, alinhado ao pressuposto de um currículo descolonizador. Sobre os sujeitos envolvidos na trajetória curricular, temos um professor que pesquisa, produz e reflete sobre suas próprias práticas a fim de formar educandos que possam também problematizar e questionar seu lugar na sociedade através do uso e da reflexão sobre a língua, dialogando com um entendimento de ILF enquanto prática situada, política e crítica. Já na Base Nacional Comum Curricular e no Currículo da Cidade, o fato de esses documentos pré-determinarem objetos do conhecimento através de tabelas normatizadoras os aproxima de uma noção universalizante e estática de conhecimento, cabendo aos sujeitos apenas a sua apropriação, a aplicação por parte do professor e a aquisição por parte do aluno, a fim de que sejam incluídos em uma sociedade e uma realidade também pronta e estável. Além disso, uma vez que alguns conhecimentos são estabelecidos, automaticamente outros são excluídos. O conceito de ILF nesses dois últimos documentos parece servir a uma lógica neoliberal de inserção do indivíduo na sociedade produtiva através da apropriação de conhecimentos prontos para fins instrumentais e mercadológicos, promovendo uma contradição no interior do documento, decorrente da presença de um conceito fluido e dinâmico de língua em documentos de caráter padronizador.

Por fim, não pretendemos, com esta pesquisa, eleger um significado único para ILF, mas sim contribuir para esclarecer os diversos entendimentos sobre o conceito de modo que essa perspectiva seja localmente ressignificada e faça sentido em cada contexto de salas de aula brasileiras, como forma de promover práticas de ensino de língua inglesa mais acolhedoras, e principalmente problematizadoras, lembrando das complexas relações de poder envolvidas no uso desse idioma, para que, em nossas práticas, não adotemos uma visão ingênua e romantizada de ILF. 


\section{REFERÊNCIAS BIBLIOGRÁFICAS}

ALPTEKIN, Cem. Understanding English as a Lingua Franca Review. ELT Journal, April, 2012, p. 247-251.

BAKER, Will; JENKINS, Jennifer. Criticising ELF. Journal of English as a Lingua Franca, 4(1), 2015, p. 191-198.

BAKHTIN, Mikhail; VOLOCHINOV, Valentin. Marxismo e filosofia da linguagem. Trad. M. Lahud; Y. F. Vieira. 11. ed. São Paulo: Hucitec, 2004 [1929].

BORDINI, Marcella; GIMENEZ, Telma. Estudos sobre inglês como língua franca no Brasil (2005-2012): uma metassíntese qualitativa. SIGNUM: Estud. Ling., Londrina, n. 17/1, jun. 2014, p. 10-43.

BOURDIEU, Pierre. Os usos sociais da ciência: por uma sociologia clínica do campo científico. São Paulo: Editora UNESP, 2004.

BRASIL. Ministério da Educação. Base Nacional Comum Curricular. Brasília: MEC, 2017. Disponível em: 〈http://basenacionalcomum.mec.gov.br/>. Acesso em: 18 julho 2019.

BROSCH, Cyril. On the conceptual history of the term Lingua Franca. Apples: Journal of applied language studies, v. 9, n.1, 2015, p. 71-85.

BUSCH, Brigitta. The Linguistic Repertoire Revisited. Applied Linguistics, 33 (5), 2012, p. 503-523.

BUSCH, Brigitta. Expanding the Notion of the Linguistic Repertoire: On the Concept of Spracherleben-The Lived Experience of Language. Applied Linguistics, 38 (3), 2017, p. 340-358.

CANAGARAJAH, Suresh. On EFL teachers, awareness, and agency. ELT Journal, v. 53/3, july 1999, p. 207-214.

CANAGARAJAH, Suresh. Lingua Franca English, Multilingual Communities and Language Acquisition. The Modern Language Journal, 91, Focus Issue, 2007, p. 923-939.

CANAGARAJAH, A. S. Translanguaging in the classroom: Emerging issues for research and pedagogy. Applied Linguistics Review, v. 2, 2011, p. 1-28.

CANAGARAJAH, Suresh. English as Translingual. In: Translingual Practice - Global Englishes and Cosmopolitan Relations. London \& New York: Routldege, 2013.

CANAGARAJAH, Suresh. Translingual Practice as Spatial Repertoires: Expanding the Paradigm Beyond Structuralist Orientations. Applied Linguistics, 39:1(1), 2017.

CANAGARAJAH, Suresh; WURR, Adrian J. Multilingual Communication and Language Acquisition: New Research Directions. The Reading Matrix, v. 11, n. 1, January 2011. 
CANDAU, Vera Maria. Direitos humanos, educação e interculturalidade: as tensões entre igualdade e diferença. Revista Brasileira de Educação, v. 13, n. 37 jan./abr., 2008.

CASTRO-GÓMEZ, Santiago. Decolonizar la Universidad: La hybris del punto cero y el diálogo de saberes. In: CASTRO-GÓMEZ, Santiago; GROSFOGUEL, Rámon. El giro decolonial: Reflexiones para una diversidad epistémica más allá del capitalismo global. Bogotá: Siglo del Hombre Editores; Universidad Central, Instituto de Estudios Sociales Contemporáneos y Pontificia Universidad Javeriana, Instituto Pensar, 2007, p. 79-91.

CASTRO-GÓMEZ, Santiago; GROSFOGUEL, Rámon. PRÓLOGO: Giro decolonial, teoría crítica y pensamiento heterárquico. In: CASTRO-GÓMEZ, Santiago; GROSFOGUEL, Rámon. El giro decolonial: Reflexiones para una diversidad epistémica más allá del capitalismo global. Bogotá: Siglo del Hombre Editores; Universidad Central, Instituto de Estudios Sociales Contemporáneos y Pontificia Universidad Javeriana, Instituto Pensar, 2007, p. 9-23.

CAVALHEIRO, Lili. Developing intercultural communication and intercultural awareness in the EFL classroom. Estudos Linguísticos e Literários. n. 65, Salvador: 2020, p. 30-48.

COUTINHO, Nina; GIMENEZ, Telma. Leitura Crítica - Componente Língua Inglesa. 2017. Disponível $\quad \mathrm{em}: \quad<$ http://basenacionalcomum.mec.gov.br/images/relatoriosanaliticos/Parecer_6_LI_Nina_Coutinho_Telma_Gimenez.pdf $>$. Acesso em: 03 de agosto de 2020.

CRYSTAL, David. English as a Global Language. Cambridge: Cambridge University Press, $2003,2^{a}$ ed.

DELL'OLIO, Francesca. Encontros interculturais entre fronteiras: corpos e afetos migrantes. Tese (Doutorado em Estudos Linguísticos e Literários em Inglês). Faculdade de Filosofia, Letras e Ciências Humanas da Universidade de São Paulo, 2018.

DUBOC, Ana Paula Martinez. Letramento crítico nas brechas da sala de aula de línguas estrangeiras. In: TAKAKI, N.; MACIEL, R. F. (Org.). Novos letramentos em terra de Paulo Freire. São Paulo: Pontes, 2014. p. 209-229.

DUBOC, Ana Paula Martinez. Atitude curricular: letramentos críticos nas brechas da sala de aula de línguas estrangeiras. Jundiaí: Paco Editorial, 2015.

DUBOC, Ana Paula Martinez. The ELF teacher education: Contributions from postmodern studies. In: GIMENEZ et al (Eds). English as a Lingua Franca in Teacher Education: A Brazilian Perspective. Berlin/ Boston: Walter de Gruyter, 2018, p. 159-187.

DUBOC, Ana Paula Martinez. Uma leitura Bakhtiniana do conceito de "Inglês como Língua Franca" no componente curricular Língua Inglesa na BNCC. Revista da Anpoll, Florianópolis, v. 1, n. 48, Jan./Jun. 2019, p. 10-22.

DUBOC, Ana Paula Martinez. Parecer crítico da $3^{\mathbf{a}}$ Versão Base Nacional Comum Curricular para a área de Língua Estrangeira Moderna. 2016. Disponível em: 
$<$ http://basenacionalcomum.mec.gov.br/images/relatoriosanaliticos/Parecer_6_LI_Ana_Paula_Martinez_Duboc.pdf $>$. Acesso em: 03 de agosto de 2020.

DUBOC, Ana Paula Martinez; GARCIA, Bianca; RODRIGUES, Lívia. Collaborative Curriculum Design under an ELF Perspective: An Innovative Experience in Southern Brazil Municipal Schools. In: XAVIER MARTIN-RUBIÓ. (Org.). Contextualising English as a Lingua Franca: From Data to Insights. 1ed. Newcastle: Cambridge Scholars Publishing, 2018, v. 1, p. 229-250.

DUBOC, Ana Paula; SIQUEIRA, Sávio. ELF feito no Brasil: expanding theoretical notions, reframing educational policies. Status Quaestionis. n. 19, 2020, p. 297-331.

DURAZZO, Sandra Tatiana Baumel. Parecer crítico - Língua Inglesa no Ensino Fundamental - Base Nacional Curricular Comum, 2017. Disponível em:

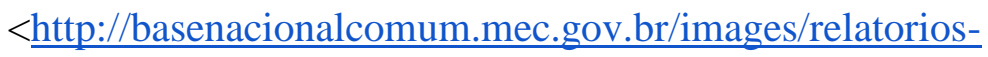
analiticos/Parecer_6_LI_Sandra_Tatiana_Baumel_Durazzo.pdf $>$. Acesso em: 03 de agosto de 2020.

DUSSEL, Inés. A transmissão cultural assediada: metamorfoses da cultura comum na escola. Cadernos de Pesquisa, v. 39, n.137, maio/ago. 2009.

FIRTH, Alan; WAGNER, Johannes. On Discourse, Communication, and (Some) Fundamental Concepts in SLA Research. The Modern Language Journal, v. 81, n. 3 (Autumn, 1997), p. 285-300.

FORQUIN, Jean-Claude. Introdução: Currículo e Cultura. In: Escola e Cultura: as bases sociais e epistemológicas do conhecimento escolar. Porto Alegre: Artmed, 1993.

FRANCINI, Eduardo. Parecer Sobre O Componente Língua Inglesa - Base Nacional Comum Curricular (Bncc), $\mathbf{3}^{\text {a }}$ Versão. 2017. Disponível em: $<$ https://docplayer.com.br/131375697-Parecer-sobre-o-componente-lingua-inglesa-dodocumento-base-nacional-comum-curricular-bncc-3a-versao.html>. Acesso em: 03 de agosto de 2020 .

FREITAS, Marco Túlio de Urzêda; PESSOA, Rosane Rocha. Rupturas e continuidades na Linguística Aplicada Crítica: uma abordagem historiográfica. Calidoscópio, v. 10, n. 02, mai/ ago, 2012.

GARCÉS, Fernando. Las políticas del conocimiento y la colonialidad lingüística y epistémica. In: CASTRO-GÓMEZ, Santiago; GROSFOGUEL, Rámon. El giro decolonial: Reflexiones para una diversidad epistémica más allá del capitalismo global. Bogotá: Siglo del Hombre Editores; Universidad Central, Instituto de Estudios Sociales Contemporáneos y Pontificia Universidad Javeriana, Instituto Pensar, 2007, p. 217-242.

GIMENEZ, Telma; CALVO, Luciana Cabrini Simões; EL KADRI, Michele Salles. Beyond Madonna: Teaching materials as windows into pre-service teachers' understandings of ELF. In: BAYYURT, Yasemin; AKCAN, Sumru. (eds) Current Perspectives on Pedagogy for English as a Lingua Franca. Berlin: De Gruyter, 2015, p. 225-237. 
GIMENEZ, Telma; EL KADRI, Michele Salles; CALVO, Luciana Cabrini Simões. Awareness raising about English as a lingua franca in two Brazilian teacher education programs. In: GIMENEZ et al (Eds). English as a Lingua Franca in Teacher Education: A Brazilian Perspective. Berlin/ Boston: Walter de Gruyter, 2018, p. 209-230.

GINZBURG, Carlo. Mitos, emblemas e sinais. São Paulo: Companhia das Letras, 1989.

GROSFOGUEL, Ramón. Descolonizando los Universalismos Occidentales: El Pluriversalismo Transmoderno Decolonial Desde Aimé Césaire Hasta Los Zapatistas. In: CASTROGÓMEZ, Santiago; GROSFOGUEL, Rámon. El giro decolonial: Reflexiones para una diversidad epistémica más allá del capitalismo global. Bogotá: Siglo del Hombre Editores; Universidad Central, Instituto de Estudios Sociales Contemporáneos y Pontificia Universidad Javeriana, Instituto Pensar, 2007, p. 63-77.

GUERRA, Luis; CAVALHEIRO, Lili; PEREIRA, Ricardo; KURT, Yavuz; OZTEKIN, Elifcan; SONMEZ-CANDAN, Ecehan; BAYYURT, Yasemin. Representations of the English as a Lingua Franca framework: identifying ELF-aware activities in Portuguese and Turkish coursebooks. RELC Journal, 2020.

HALL, Stuart. Representation: Cultural Representation and Signifying Practices. London/Thousand Oaks/New Delhi: Sage/ The Open University, 1997.

HALL, Stuart. A identidade cultural na pós-modernidade. 10. ed. Rio de Janeiro: DP\&A, 2005 .

HELLER, Monica; McELHINNY, Bonnie. Language, Capitalism, Colonialism: toward a critical history. Toronto, Ontario: University of Toronto Press, 2017.

JENKINS, Jennifer. The Phonology of English as an International Language. Oxford University Press, 2000.

JENKINS, Jennifer. Implementing an International approach to English Pronunciation: the role of teacher attitudes and identity. TESOL QUARTERLY, v. 39, n. 3, September, 2005, p. 535543.

JENKINS, Jennifer. Current Perspectives on Teaching World Englishes and English as a Lingua Franca. TESOL QUARTERLY. v. 40, n. 1, March 2006a, p. 157-181.

JENKINS, Jennifer. Points of view and blind spots: ELF and SLA. International Journal of Applied Linguistics, v. 16, n. 2, 2006b, p. 137-162.

JENKINS, Jennifer. English as a Lingua Franca: interpretations and attitudes. World Englishes, v. 28, n. 2, 2009, p. 200-207.

JENKINS, Jennifer. Repositioning English and multilingualism in English as a lingua franca. Englishes in Practice, 2(3), 2015, p. 49-85.

JENKINS, Jennifer. An ELF perspective on English in the post-Brexit EU. World Englishes, 36., 2017, p. 343-346. 
JENKINS, Jennifer; COGO, Alessia; DEWEY, Martin. Review of developments in research into English as a lingua franca. Language Teaching, 44, (3), 2011, p. 281-315.

JORDÃO, Clarissa Menezes. English as a foreign language, globalisation and conceptual questioning. Globalisation, Societies and Education, v. 7, n. 1, March 2009, p. 95-107.

JORDÃO, Clarissa Menezes. A posição do professor de inglês no Brasil: hibridismo, identidade e agência. Rev. Letras \& Letras, v.26, n. 2, jul./dez. 2010, p. 427-442.

JORDÃO, Clarissa Menezes. ILA - ILF - ILE - ILG: Quem dá conta? RBLA, Belo Horizonte, v. 14, n. 1, 2014, p. 13-40.

JORDÃO, Clarissa Menezes. Southern epistemologies, decolonization, English as a Lingua Franca: ingredients to an effective Applied Linguistics potion. Waseda Working Papers in ELF. v. 8, 2019.

JORDÃO, Clarissa Menezes; MARQUES, Anderson Nalevaiko. English as a Lingua Franca and critical literacy in teacher Education: Shaking off some "good old" habits. In: GIMENEZ et al (Eds). English as a Lingua Franca in Teacher Education: A Brazilian Perspective. Berlin/Boston: Walter de Gruyter, 2018, p. 53-68.

LOPRIORE, Lucilla; VETTOREL, Paola. Promoting Awareness of Englishes and ELF in the English Language Classroom. In: BOWLES, Hugo; COGO, Alessia (eds). International Perspectives on English as a Lingua Franca: Pedagogical insights. London: Palgrave Macmillan, 2015, p. 13-34.

MALDONADO-TORRES, Nelson. Sobre la colonialidad del ser: contribuciones al desarrollo de un concepto. In: CASTRO-GÓMEZ, Santiago; GROSFOGUEL, Rámon. El giro decolonial: Reflexiones para una diversidad epistémica más allá del capitalismo global. Bogotá: Siglo del Hombre Editores; Universidad Central, Instituto de Estudios Sociales Contemporáneos y Pontificia Universidad Javeriana, Instituto Pensar, 2007, p. 127-167.

MENEZES DE SOUZA, Lynn Mario T. Cultura, Língua e Emergência dialógica. R. Let. \& Let, Uberlândia-MG, v. 26, n. 2, jul./dez. 2010, p. 289-306.

MIGNOLO, Walter. El Pensamiento Decolonial: Desprendimiento y Apertura, Un manifiesto. In: CASTRO-GÓMEZ, Santiago; GROSFOGUEL, Rámon. El giro decolonial: Reflexiones para una diversidad epistémica más allá del capitalismo global. Bogotá: Siglo del Hombre Editores; Universidad Central, Instituto de Estudios Sociales Contemporáneos y Pontificia Universidad Javeriana, Instituto Pensar, 2007, p. 25-46.

MIGNOLO, Walter. Epistemic disobedience, independent thought and de-colonial freedom. Theory, Culture \& Society, 2009 (SAGE, Los Angeles, London, New Delhi, and Singapore), v. 26(7-8), p. 1-23.

MIGNOLO, Walter; WALSH, Catherine E. On Decoloniality: concepts, analytics, praxis. Durham: Duke University Press, 2018. 
MODIANO, Marko. English in a post-Brexit European Union. World Englishes, 2017, p. 313 327.

MONTOYA, Angélica Montes; BUSSO, Hugo. Entrevista a Ramón Grosfoguel. Polis: Revista Latinoamericana, 18, 2007.

OLIVEIRA, Maria Marly de. Como fazer pesquisa qualitativa. Petrópolis: Vozes, 2007.

O'REGAN, John P. English as Lingua Franca: an immanent critique. Applied Linguistics, 35.5, 2014.

PARADOWSKI, Michał B. Barbara Seidlhofer: Understanding English as a Lingua Franca: A Complete Introduction to the Theoretical Nature and Practical Implications of English used as a Lingua Franca (Review article). The Interpreter and Translator Trainer, 7(2), 2013, p. 312-320.

PENNYCOOK, Alastair. Performativity and Language Studies. Critical Inquiry in Language Studies, 1(1), March, 2004, p. 1-19.

PENNYCOOK, Alastair. The cultural politics of English as an International language. United Kingdom: Longman Group Limited, 1994.

PENNYCOOK, Alastair. Critical Applied Linguistics: a critical introduction. New Jersey: Lawrence Erlbaum Associates, Inc., 2001.

PENNYCOOK, Alastair. Uma linguística aplicada transgressiva. In: MOITA LOPES, Luiz Paulo (Org.). Por uma linguística aplicada indisciplinar. São Paulo: Parábola, 2006, p. 6784.

PENNYCOOK, A. The monolingual myth. Language on the move. August 10, 2010. Available at http://www.languageonthemove.com/recent-posts/the-monolingual-myth. Access August 11, 2013.

PENNYCOOK, Alastair; PESSOA, Rosane Rocha; SILVESTRE, Viviane Pires Viana. Reflections on Critical Applied Linguistics: A conversation with Alastair Pennycook. Signótica, Goiânia, v. 28, n. 2, jul./dez. 2016, p. 613-632.

QUIJANO, Aníbal. Colonialidad del poder y clasificación social. In: CASTRO-GÓMEZ, Santiago; GROSFOGUEL, Rámon. El giro decolonial: Reflexiones para una diversidad epistémica más allá del capitalismo global. Bogotá: Siglo del Hombre Editores; Universidad Central, Instituto de Estudios Sociales Contemporáneos y Pontificia Universidad Javeriana, Instituto Pensar, 2007, p. 93-126.

RAJAGOPALAN, K. The rigmarole of intelligibility in World English(es) - Or, on making sense of it all or, if you like, making the very idea of intelligibility intelligible. R. Let. \& Let. Uberlândia-MG, v.26 n.2, jul/dez 2010, p. 477-492. 
RAJAGOPALAN, K. O "World English": um fenômeno muito mal compreendido. In: CALVO, L. C. S; EL KADRI, M. S.; GIMENEZ, T. (Org.). Inglês como língua franca: ensino-aprendizagem e formação de professores. Campinas: Pontes, 2011.

SACRISTÁN, J. Gimeno. Currículo e diversidade cultural. In: Territórios contestados: O currículo e os novos mapas políticos e culturais. Petrópolis: Vozes, 1995.

SÁ-SILVA, Jackson Ronie; ALMEIDA, Cristóvão Domingos de; GUINDANI, Joel Felipe. Pesquisa documental: pistas teóricas e metodológicas. Revista Brasileira de História \& Ciências Sociais. Ano I, n. I, julho de 2009.

SÃO PAULO. Secretaria Municipal de Educação. Direitos de aprendizagem dos ciclos interdisciplinar e autoral: Língua Inglesa. São Paulo: SME/COPED, 2016. (Coleção Componentes Curriculares em Diálogos Interdisciplinares a Caminho da Autoria).

SÃO PAUlO. Secretaria Municipal de Educação. Currículo da Cidade Ensino Fundamental: Língua Inglesa. São Paulo: SME/COPED, 2017.

SEIDLHOFER, Barbara. Double Standards: teacher education in the Expanding Circle. World Englishes, v. 18, n. 2, 1999, p. 233-245.

SEIDLHOFER, Barbara. Closing a conceptual gap: the case for a description of English as a Lingua Franca. International Journal of Applied Linguistics, v. 11, n. 2, 2001.

SEIDLHOFER, Barbara. Key concepts in ELT: English as a Lingua Franca. ELT Journal, v. 59/4 October, 2005.

SEIDLHOFER, Barbara. Common ground and different realities: world Englishes and English as a língua franca. World Englishes, v. 28, n. 2, 2009, p. 236-245.

SEIDLHOFER, Barbara; WIDDOWSON, H. Thoughts on independent English. World Englishes, 2017, p. 360-362.

SIFAKIS, Nicos C. ELF Awareness in English Language Teaching: Principles and Processes. Applied Linguistics, 40/2: Oxford University Press, 2017, p. 288-306.

SILVA, Tomaz Tadeu da. Documentos de identidade: uma introdução às teorias do currículo. Belo Horizonte: Autêntica Editora, 2019.

SIQUEIRA, Domingos Sávio Pimentel. Inglês como língua franca: O desafio de ensinar um idioma desterritorializado. In: GIMENEZ, Telma; CALVO, Luciana Cabrini Simões; EL KADRI, Michele Salles (eds.). Inglês como língua franca: ensino-aprendizagem e formação de professores. Campinas: Pontes Editores, 2011, p. 87-116.

SIQUEIRA, Domingos Sávio Pimentel. Ensino de inglês como língua franca na escola pública: por uma crença no seu (bom) funcionamento. Muitas Vozes, Ponta Grossa, v.1, n.1, 2012, p. 127-149. 
SIQUEIRA, Domingos Sávio Pimentel. Por um ensino intercultural de Inglês como língua franca. Estudos Linguísticos e Literários, n. 48, jul./dez. 2013, p. 5-39.

SIQUEIRA, Domingos Sávio Pimentel. English as a Lingua Franca and ELT materials: Is the plastic world really melting? In: BAYYURT, Yasemin; AKCAN, Sumru. (eds) Current Perspectives on Pedagogy for English as a Lingua Franca. Berlin: De Gruyter, 2015, p. 239257.

SIQUEIRA, Domingos Sávio Pimentel. English as a Lingua Franca and teacher education: Critical educators for an intercultural world. In: GIMENEZ et al (Eds). English as a Lingua Franca in Teacher Education: A Brazilian Perspective. Berlin/ Boston: Walter de Gruyter, 2018, p. 87-114.

SOARES, Ana Luísa de Castro; ZAIDAN, Junia Claudia Santana de Mattos. O estado da arte da Linguística Aplicada Crítica no Brasil: Um diagnóstico das pesquisas de LAC publicadas em periódicos. International Congress of Critical Applied Linguistics. Brasília, Brasil, Outubro, 2015.

SOUSA, Lucília Maria Abrahão; GARCIA, Dantielli Assumpção; FARIA, Daiana de Oliveira. Paradigma indiciário, língua-concha, recorte e funcionamento: A metodologia em AD. Línguas e Instrumentos Linguísticos, n. 33, jan/jun, 2014, p. 93-108.

SOUSA SANTOS, Boaventura de. Para além do pensamento abissal: das linhas globais a uma ecologia de saberes. Revista Novos Estudos CEBRAP 79, novembro de 2007, p. 71-94.

SOUSA SANTOS, Boaventura de. Epistemologies of the South and the Future. From the European South: a transdisciplinary journal of postcolonial humanities, 1, 2016, p. 17-29.

SUASSUNA, Lívia. Pesquisa qualitativa em Educação e Linguagem: histórico e validação do paradigma indiciário. Perspectiva, Florianópolis, v. 26, n. 1, jan/jun, 2008, p. 341-377.

THE DOUGLAS FIR GROUP. A Transdisciplinary Framework for SLA in a Multilingual World. The Modern Language Journal, 100, Supplement 2016.

WALSH, Catherine. Interculturalidad y colonialidad del poder: Un pensamiento y posicionamiento "otro" desde la diferencia colonial. In: CASTRO-GÓMEZ, Santiago; GROSFOGUEL, Rámon. El giro decolonial: Reflexiones para una diversidad epistémica más allá del capitalismo global. Bogotá: Siglo del Hombre Editores; Universidad Central, Instituto de Estudios Sociales Contemporáneos y Pontificia Universidad Javeriana, Instituto Pensar, 2007, p. 47-62.

WALSH, Catherine. Interculturalidad y (de)colonialidad: Perspectivas críticas y políticas. Visão Global, Joaçaba, v. 15, n. 1-2, jan./dez. 2012, p. 61-74. 